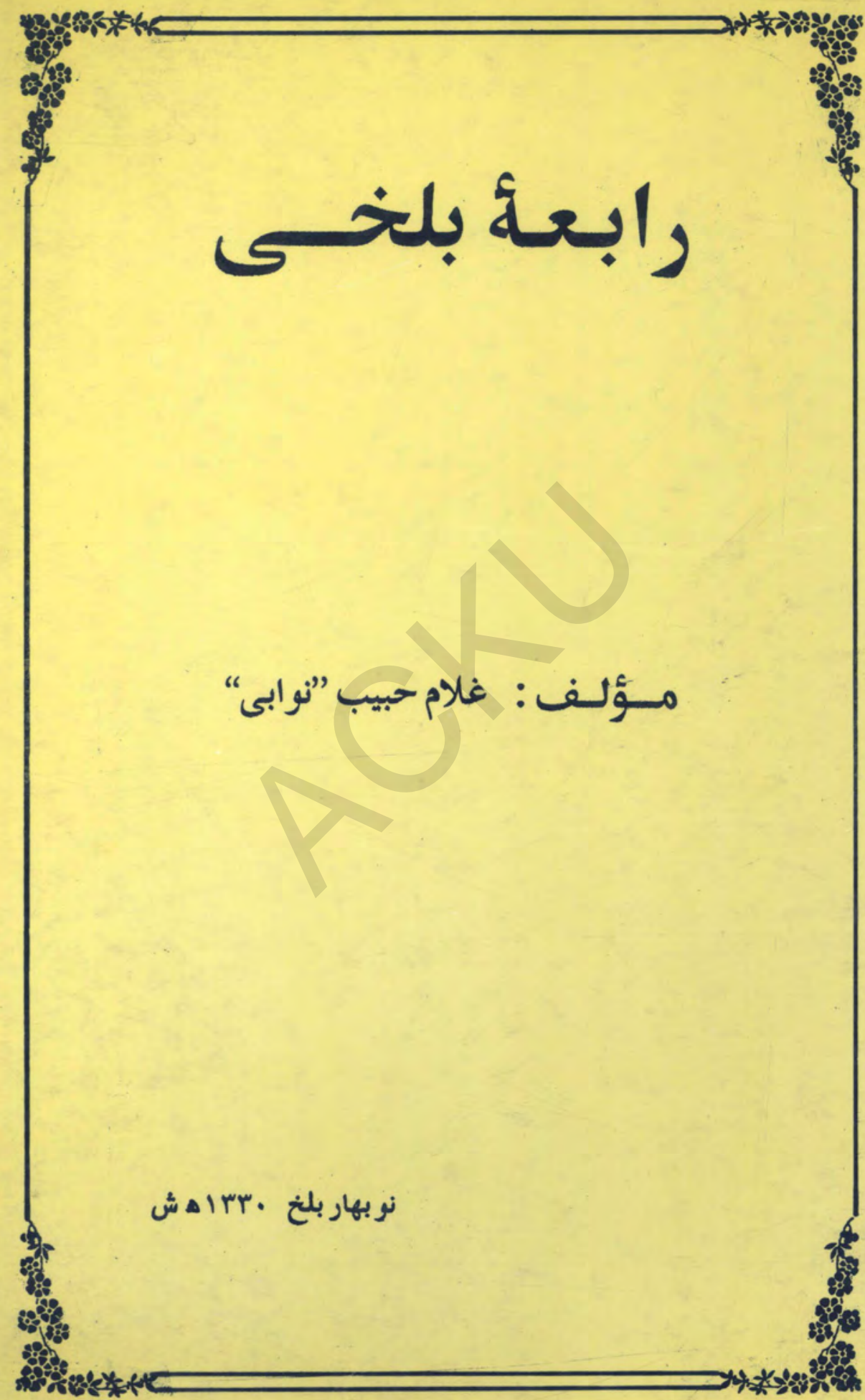




\section{رابعـأ بلخــى}

مــؤلــف : غلام حبيب "نوابى"

نو بهار بلخ •rrآهـ 


\section{مشـخصـات كــتاب}

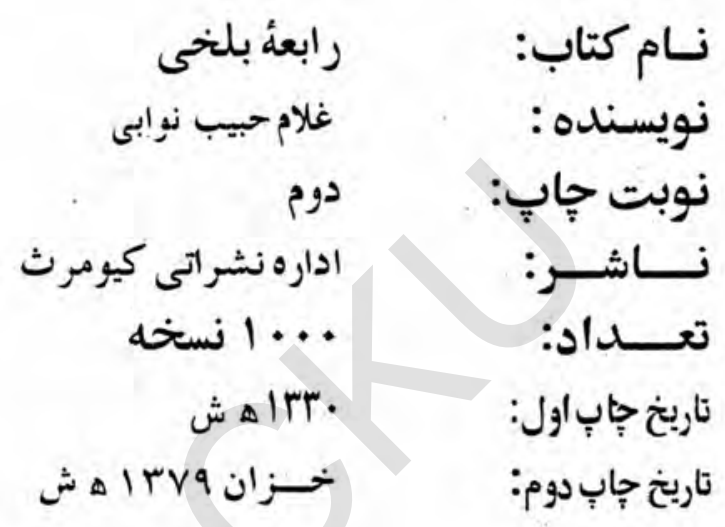

حق جاب به ناشر محفوظ است

$$
\begin{aligned}
& \text { مركز كمِييوترتخارستان }
\end{aligned}
$$

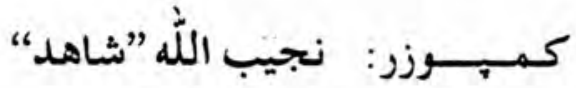

$$
\begin{aligned}
& \text { شمارةتيلفون: } \\
& \text { E-Mail: sass@brain.net.pk }
\end{aligned}
$$




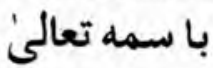

\section{جحنل ستخن در خصو ص رابعلُ بلنحى}

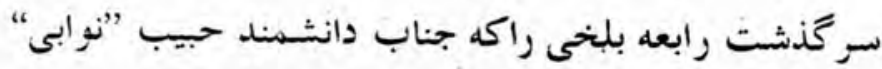

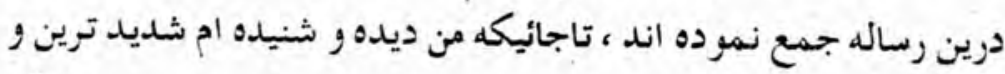

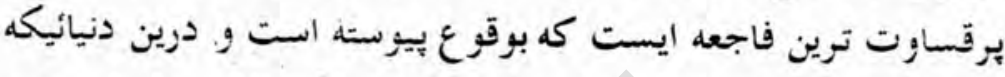

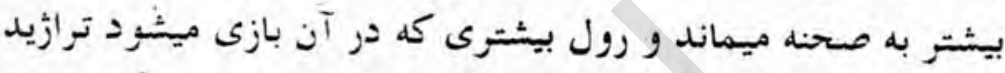

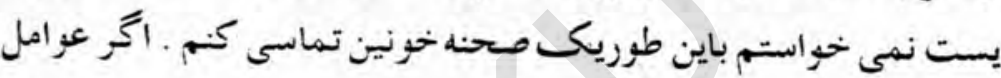
ذيل نميبرد:

1 - اينكه عشق رابعه عشقى بود باكى وبيطرف يعنى هدف آن

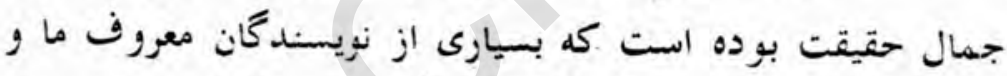

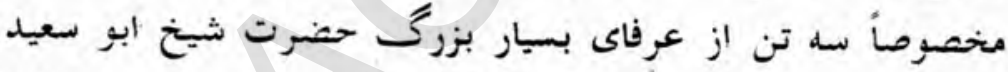

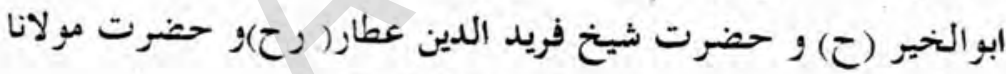
عبدالرحمن جامى (رح) برين مطلب شهادت داده اند اند.

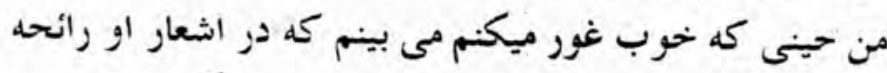

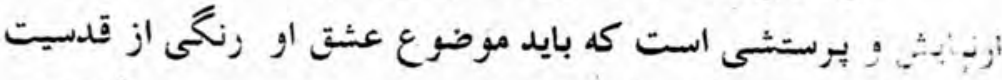

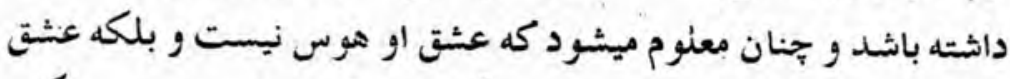

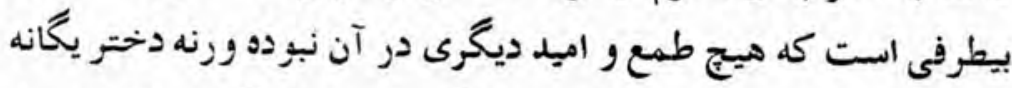

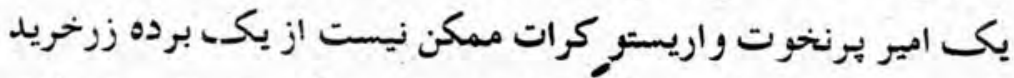

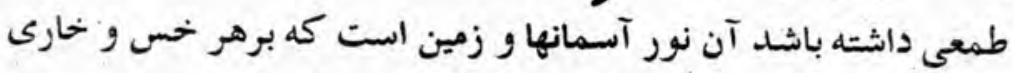

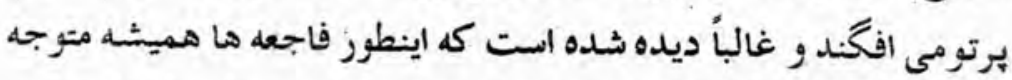

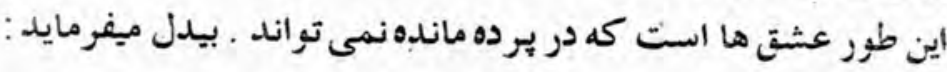




\section{رسسوائي ورعشت-مستورى و حسن}

مجنون وصحسرا- ليسلى و محسل

r- رابعه معاصر است به " رود كى" استاء اول سخن ماكه

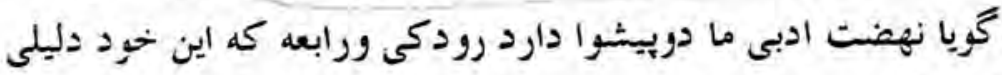

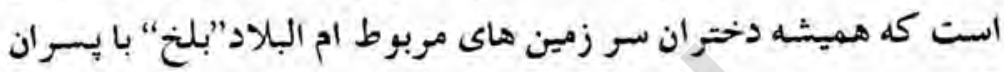

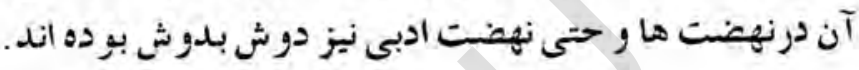

r-rابعه قطع نظر ازينكه دخترى است او بذات خري از هيج

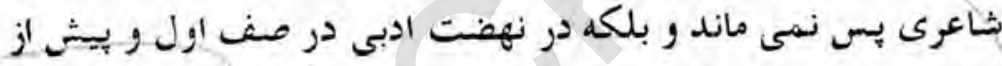

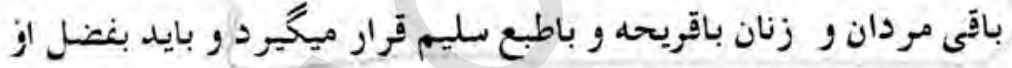

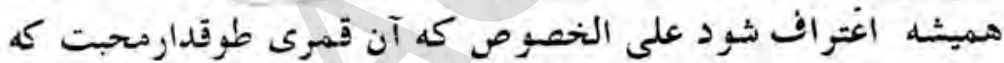

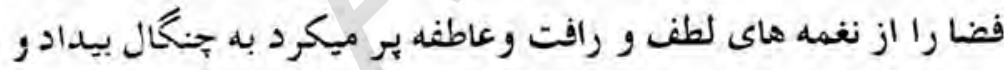
برقساوت شاهين غضب و كين و نفرت د جار شند.

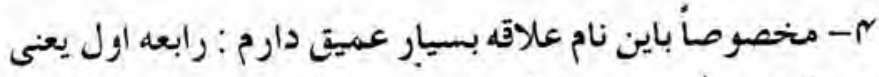

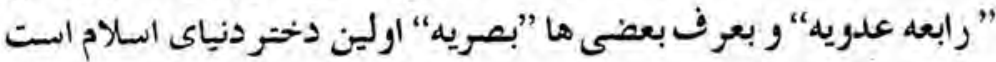

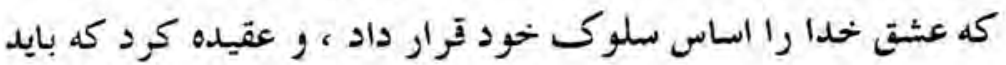

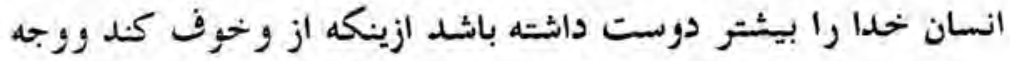

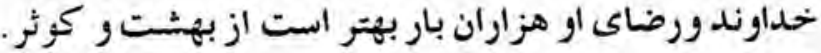

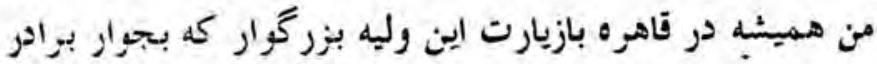

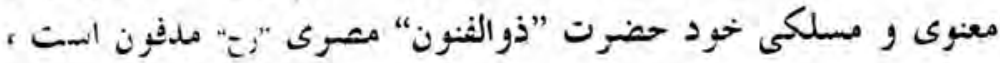


رابعئ بلفي

?

مشرف ميشدمو از روح بزرئو جاويد او كسب نزهتو هدت ميكردم

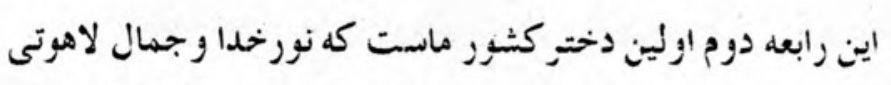

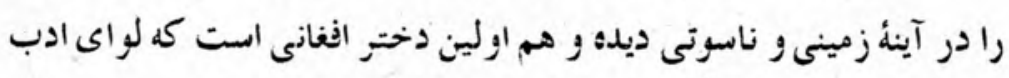

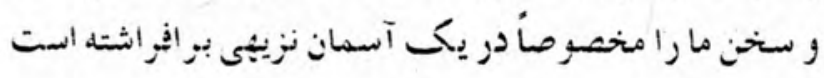

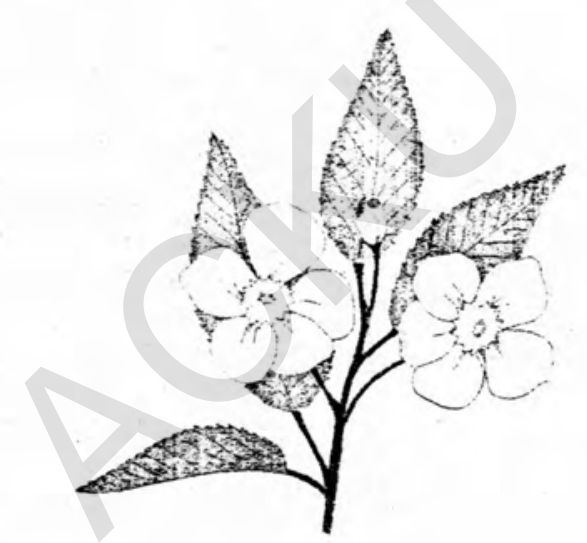

بـاحسترام

حـمـير 


\section{شاهلخحت شهيد بلخ}

"رابعه بلحى" "اسرتايامطالعه كردم درين كتاب مطالب

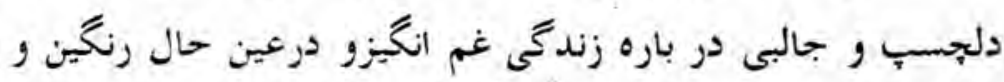

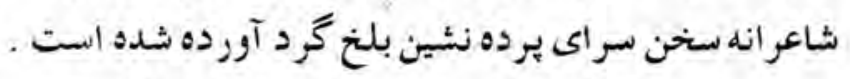

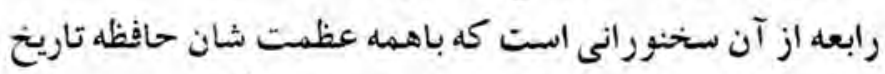

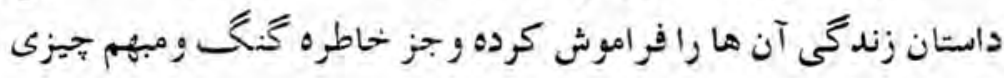

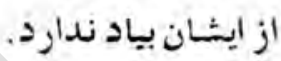

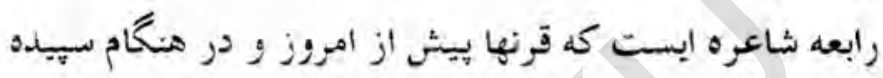

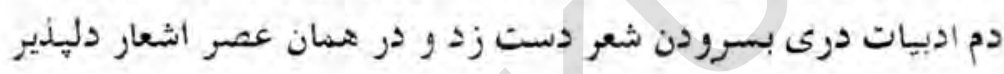

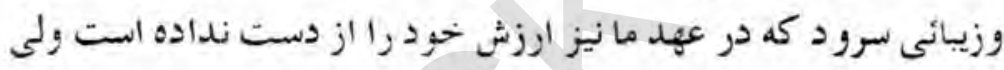

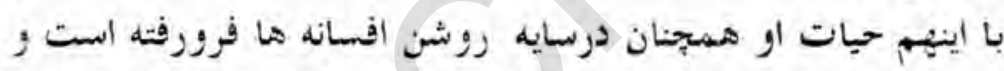

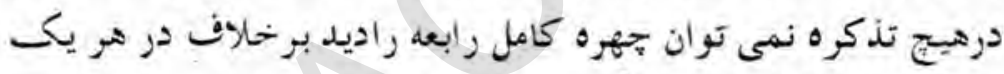

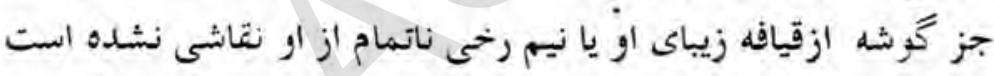

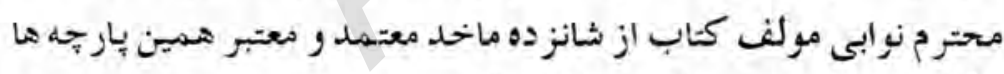

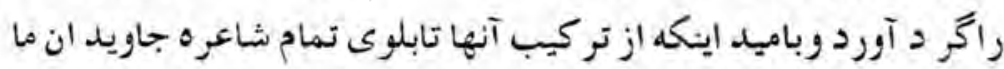

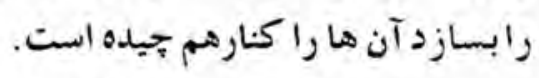

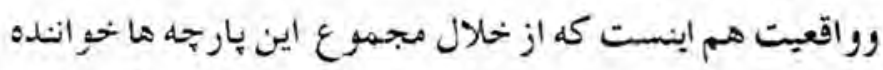

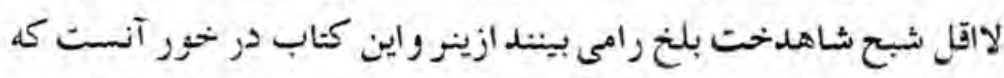

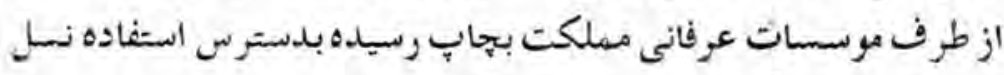

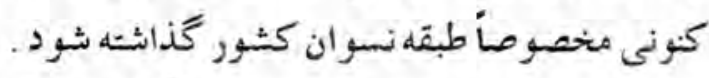
سنيل محمود فارونى 


\section{سر كُشـت خرونين رابعه}

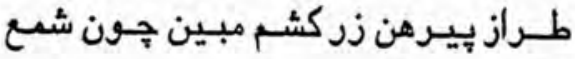

كـهـ سـوز هاسـت نهـان لرون يـــيرهنم

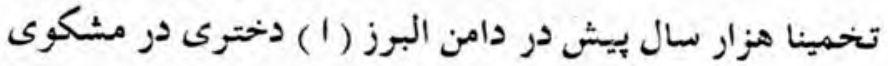

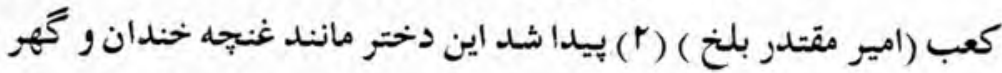

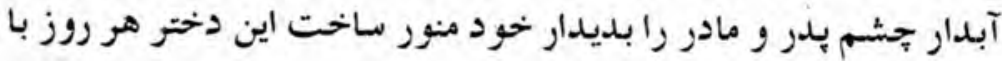

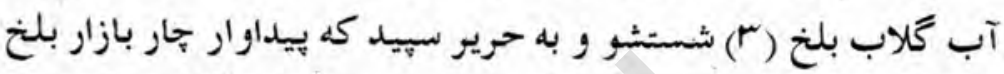

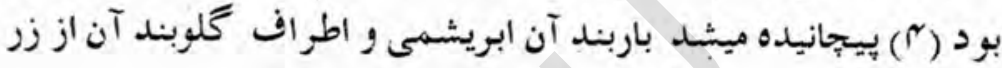

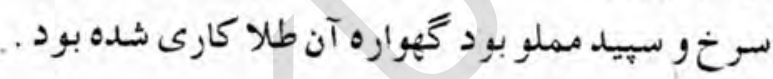

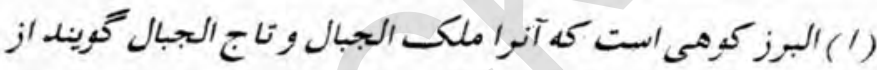

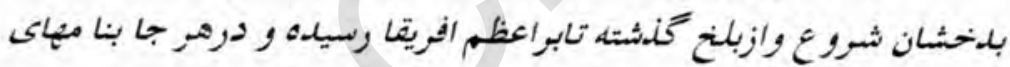
مختلف ياد ميئود.

(r) (r) ور باب بلخ ميكويند هيخ شهرى را اينجنين مردمان و وعمارات

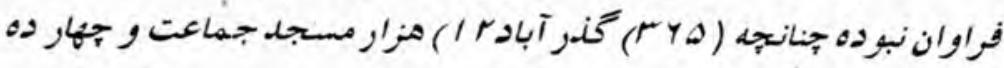

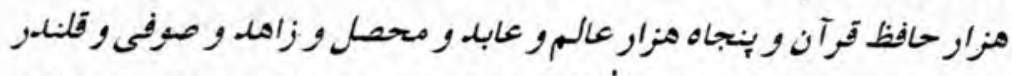

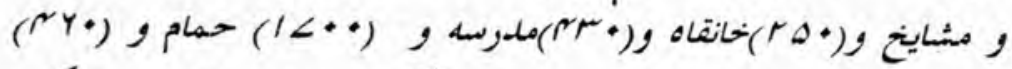

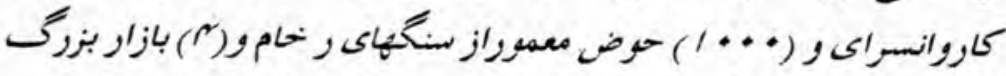

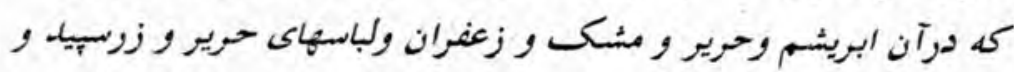

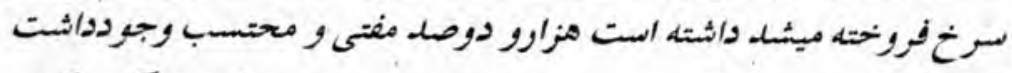

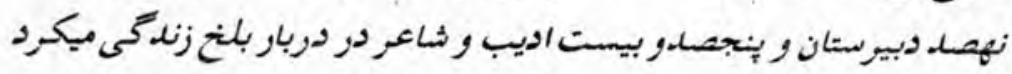
جهار صل حنبد يخلان و سه صلد حوض سبيلى ده درده و يكهزارو دوصا. 
سردا به موجود ببود.

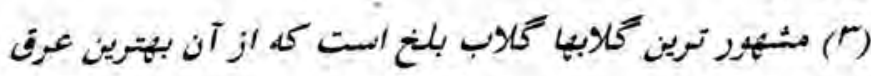

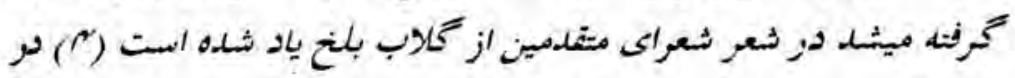

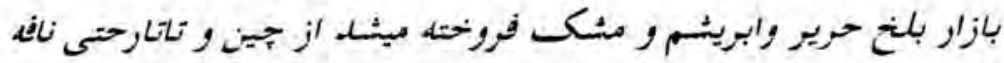

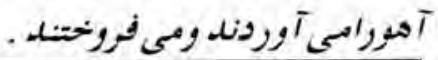

نام اين دختر فرخنده را رابعه گَذاشستد شعراى معروف معاصر

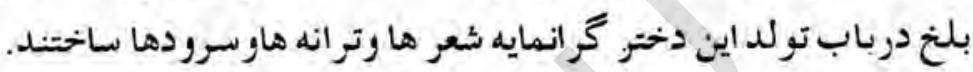

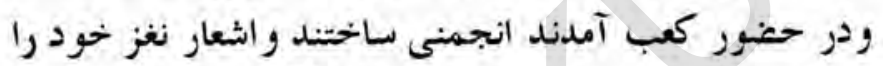

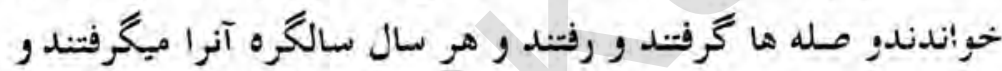

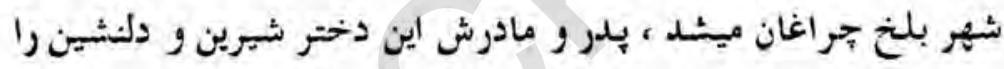

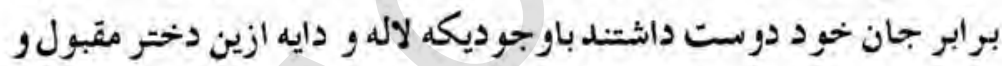

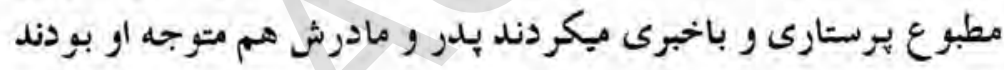

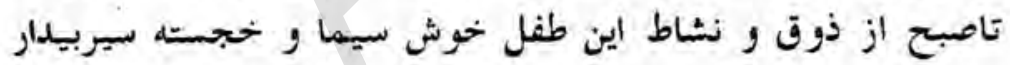

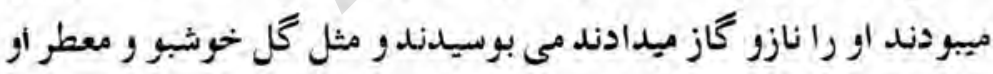

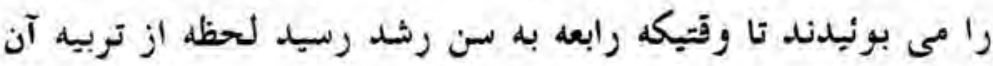

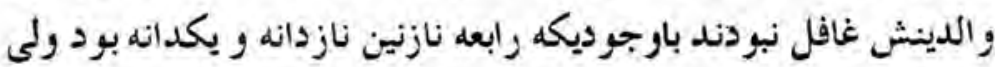

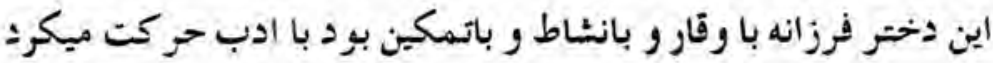

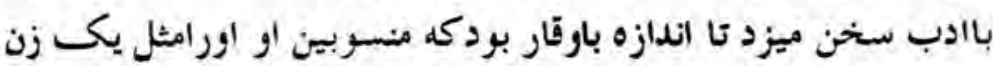

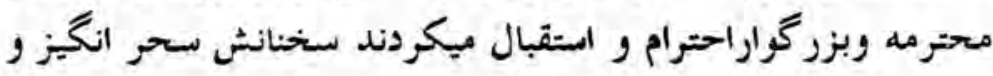

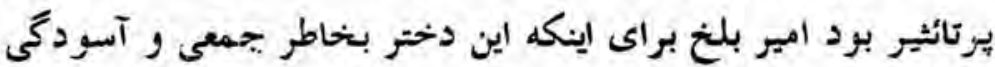

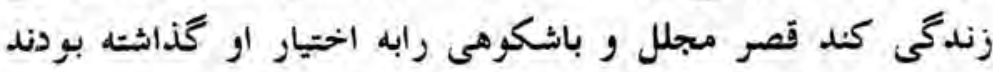




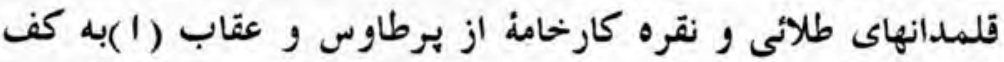

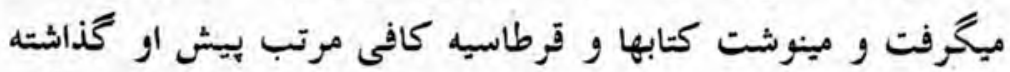

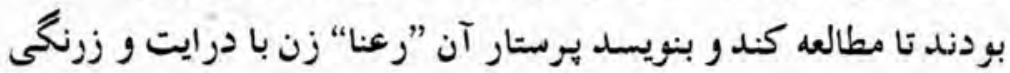

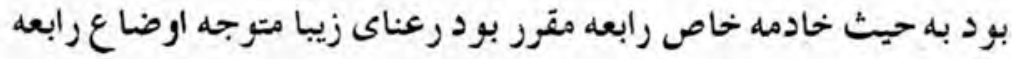

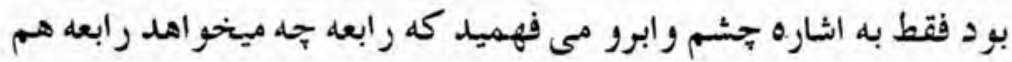

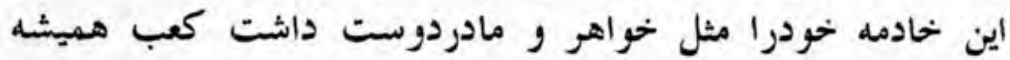

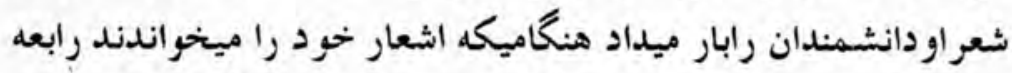

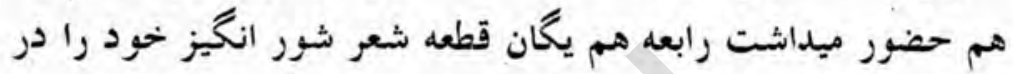

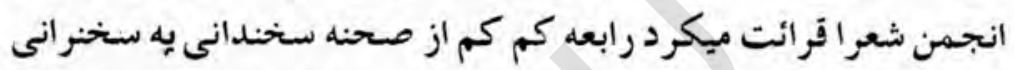

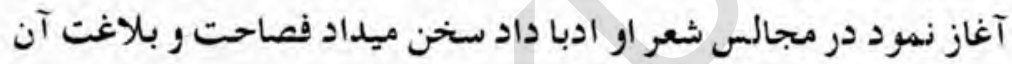

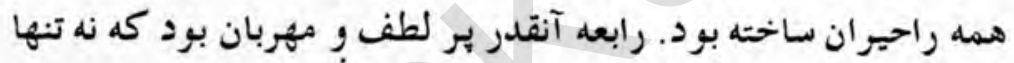

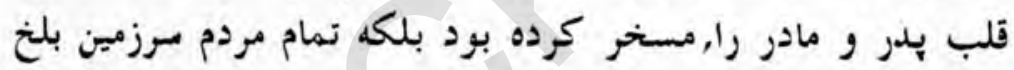

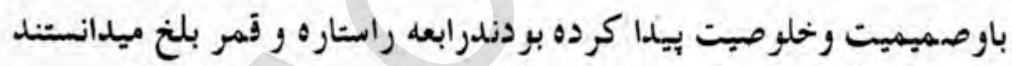

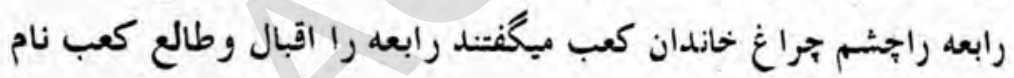

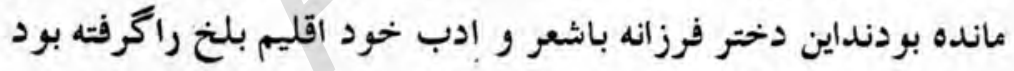

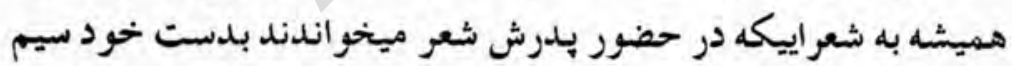

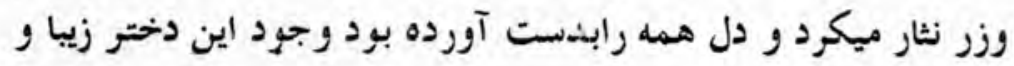

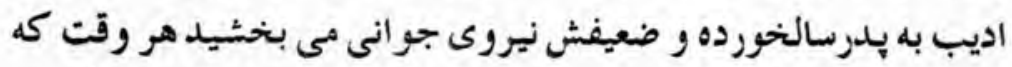

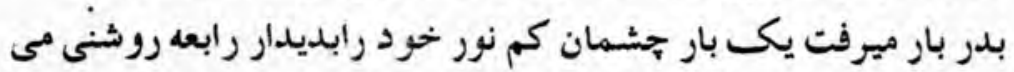

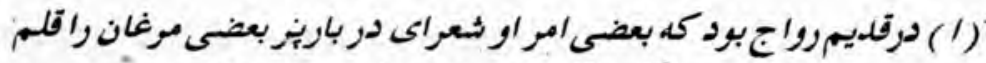

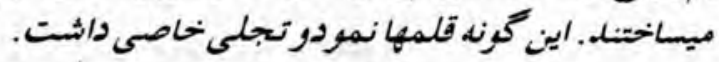


بخشيد ميخفت رابعه جان جان بدر؟ نورجئمان بـدر ؟ بحدا حافظ خحلا ترابه حفظو امان خود اشته باشد.

بدرش كه ازدر بار باز ميخثيت رابعه به استقبال او ميرفت باند

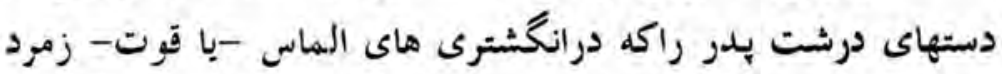

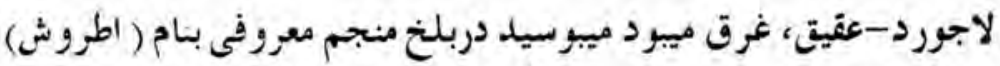

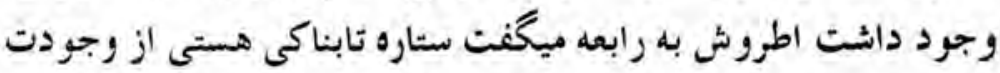

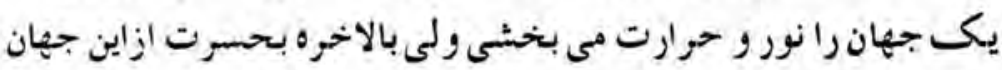

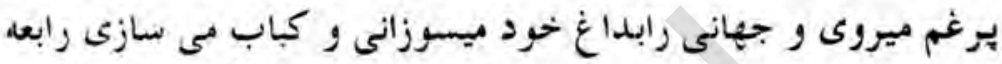

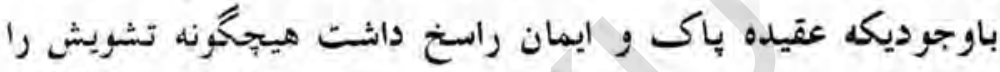

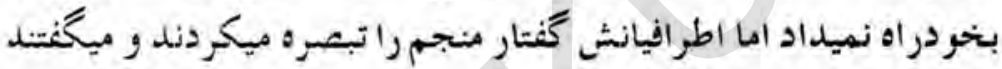

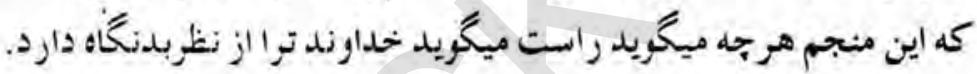

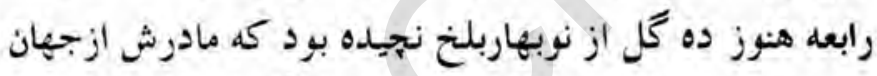

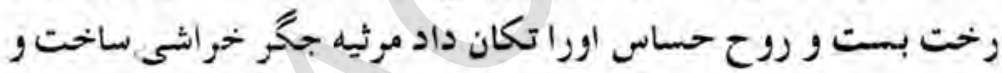

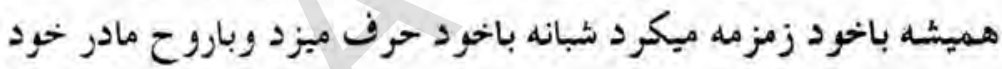

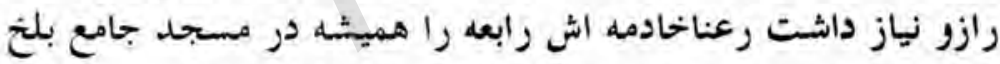

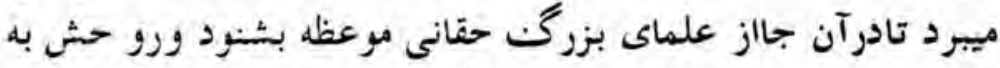

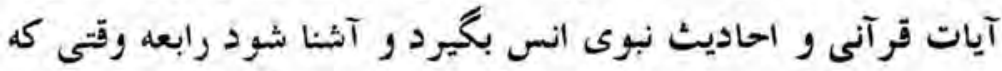

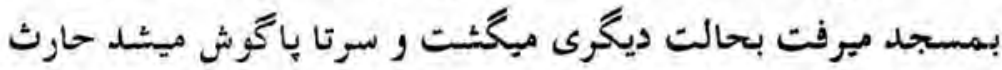

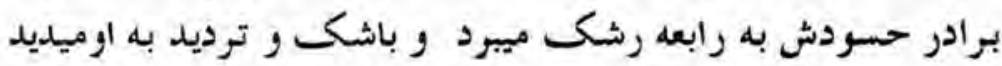

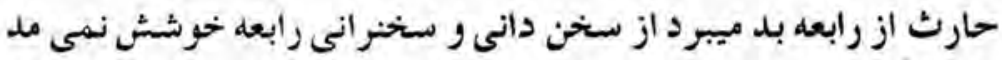

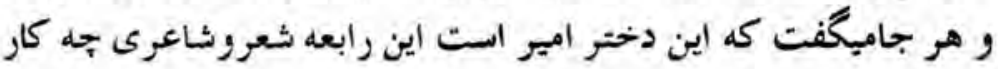

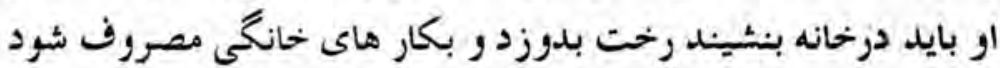

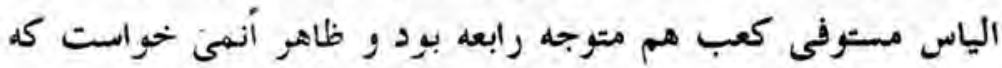




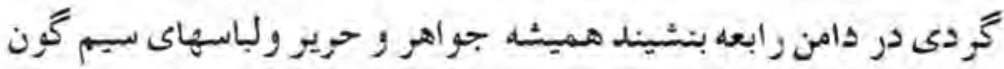

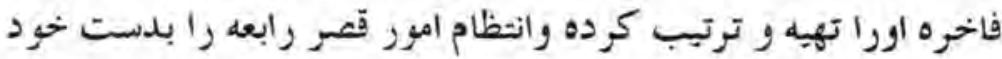

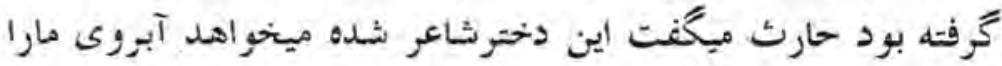

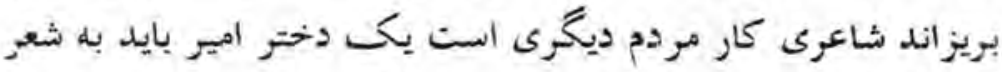

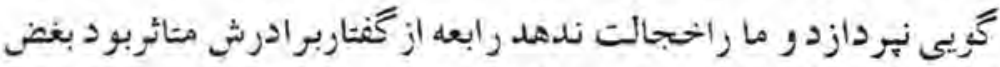

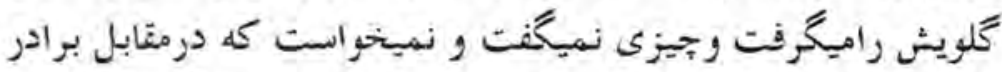

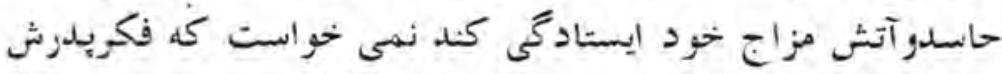

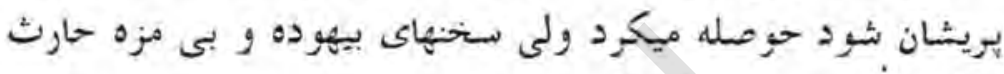

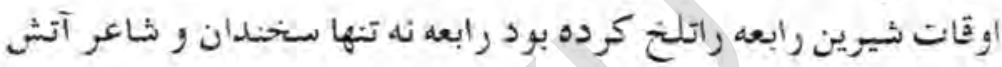

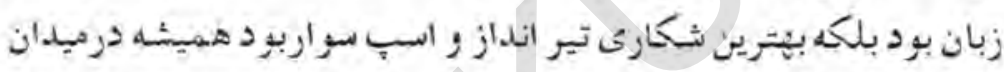

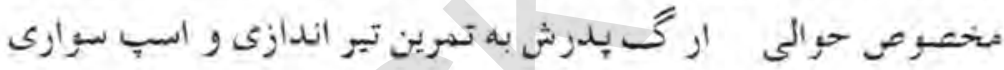

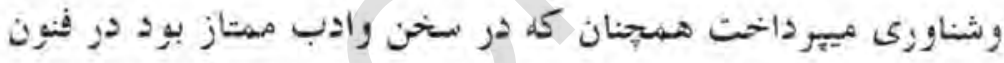

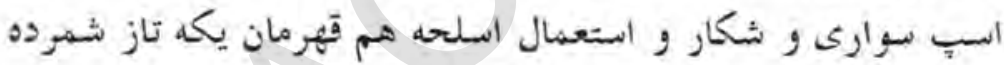

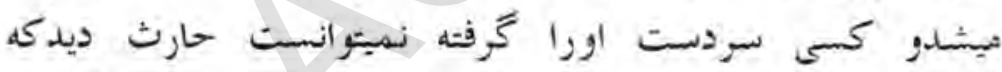

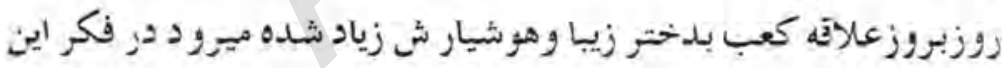

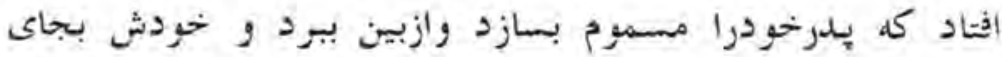

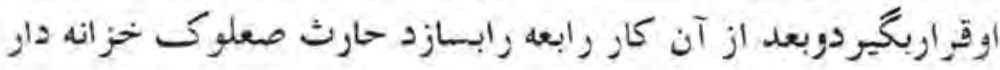

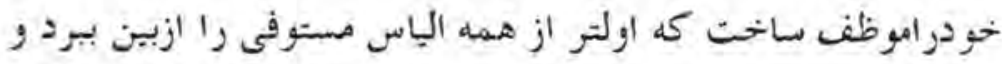

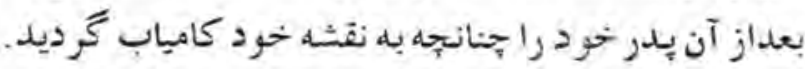

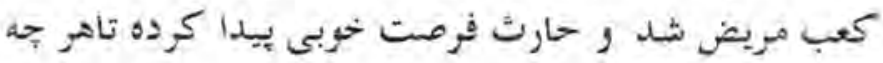

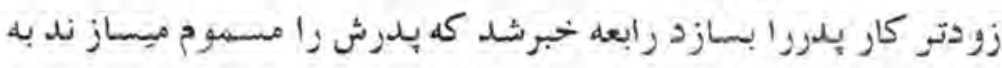

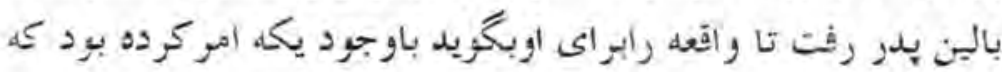

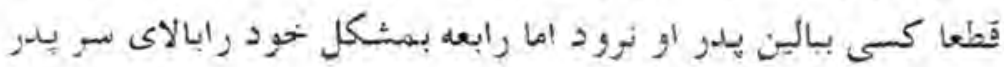


بيمار خود رمانيدرورى گلبرق تر خودرابروى بدر ماليد ودستهاى بلورين رابرسينه بدر خذاشت ورئت

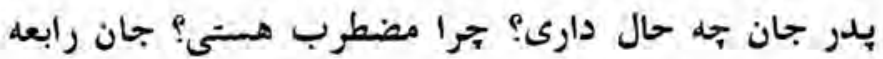
فدايت دشسمنان و حسودان در كمين ماست ميخواهند كه مارا ازبين

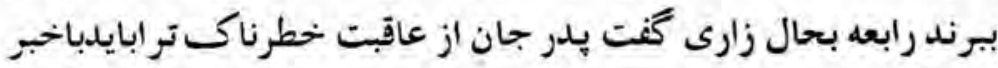

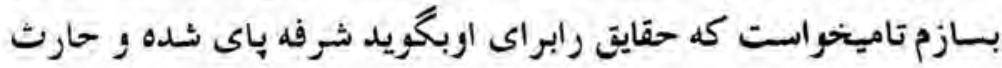

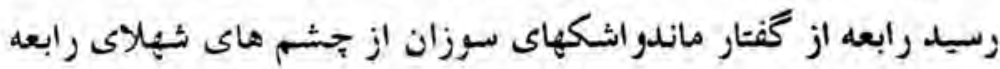

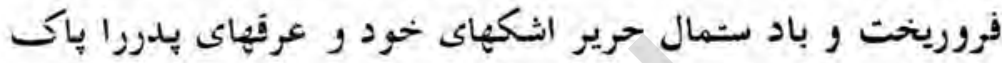

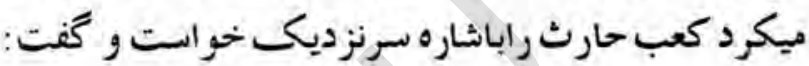

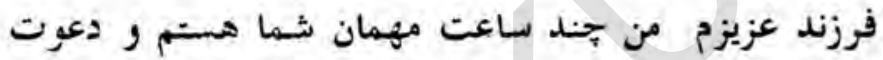

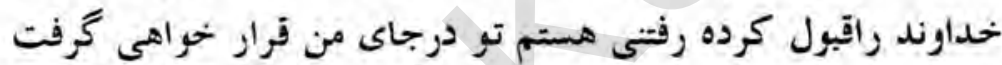

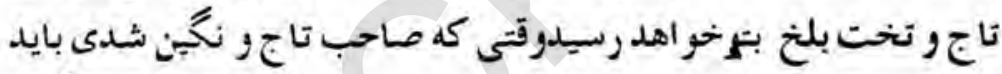

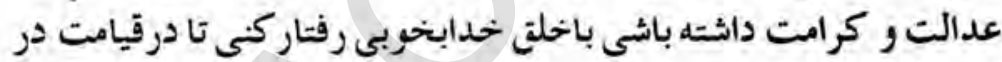

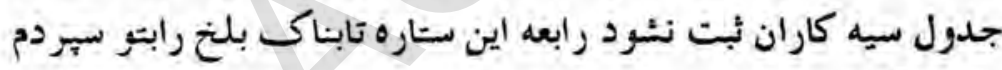

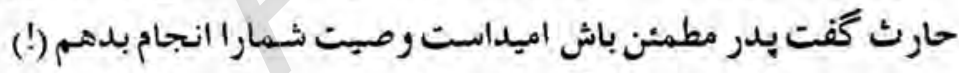

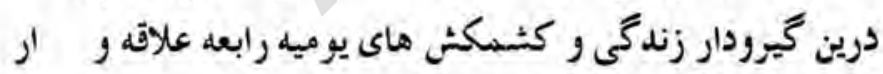

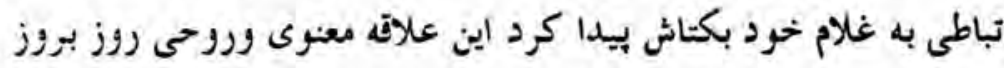

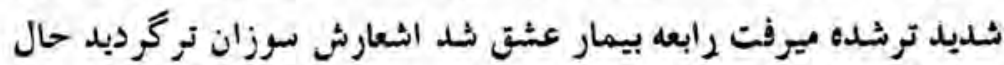

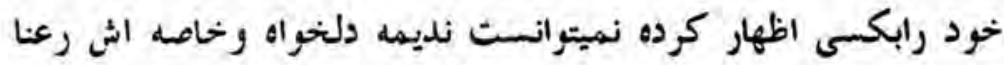

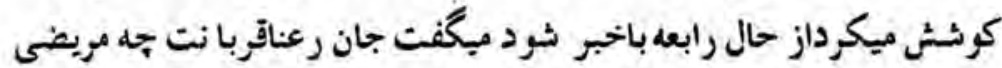

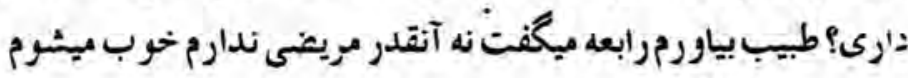

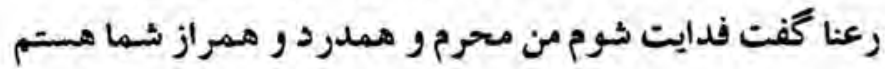

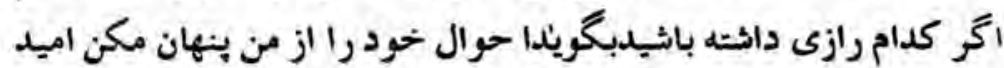


است جاره سازى كرده بتوانم رابعه گفت رعنا دردستگاه برادرم

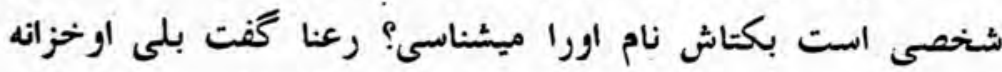

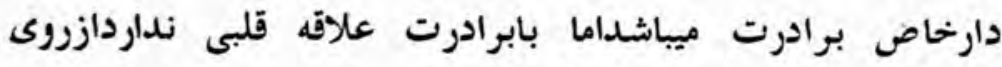

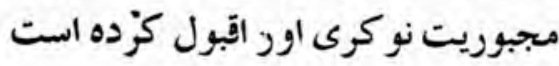

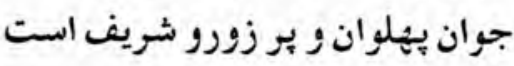
رابعه گفت توبمن خيلى نزديكى من يكـ بار اين جوان روان را ديلده

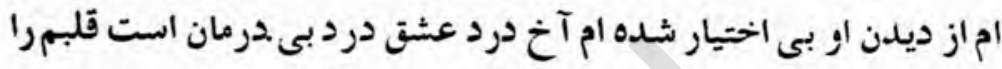

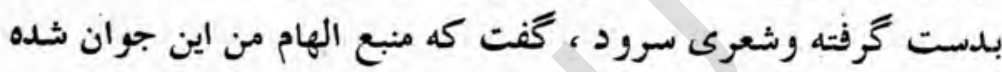

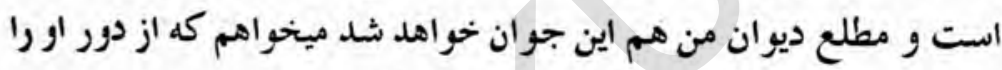

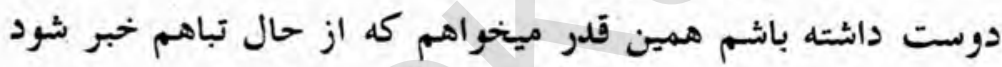

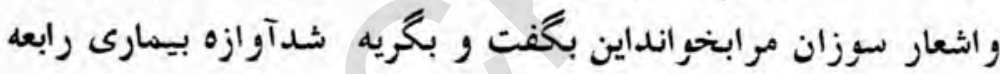

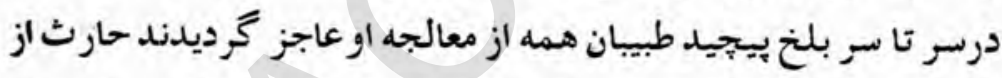

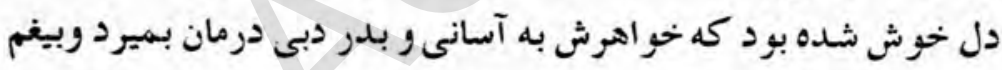

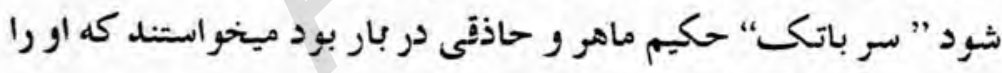

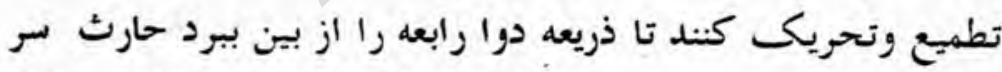
باتكى را بيش رابعه فرستادتانبض اوراديده بمعالجه اش بيردازد

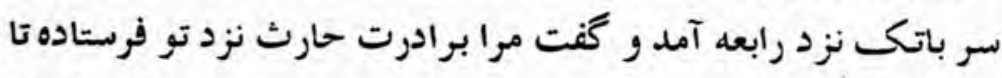

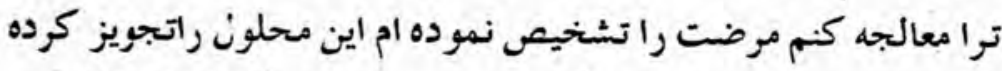

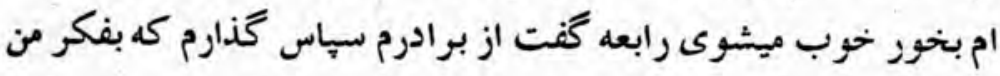

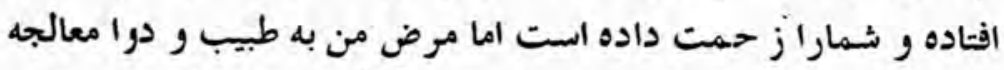

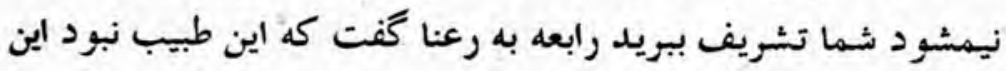

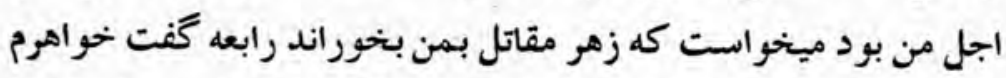

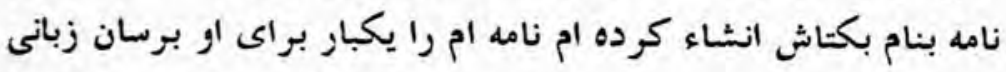




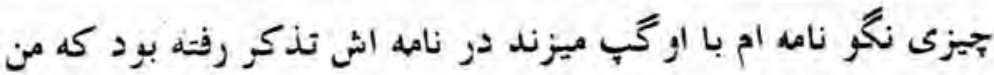

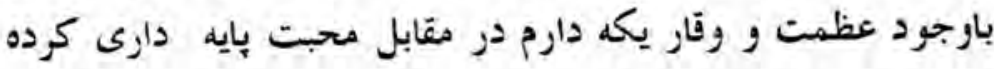

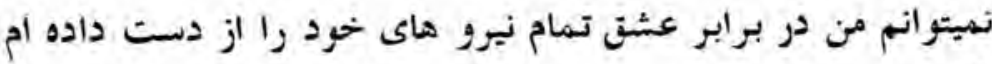

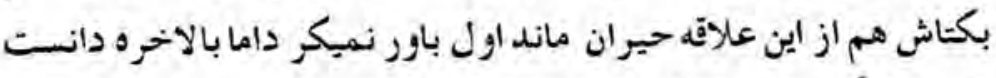

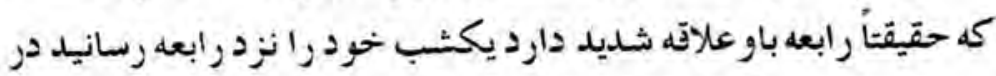

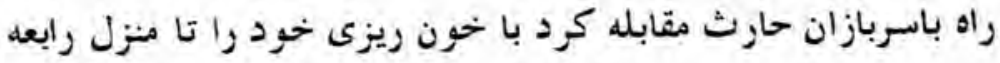

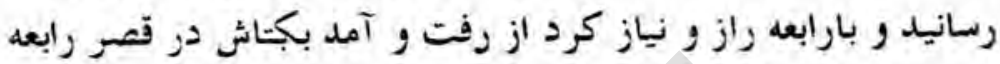

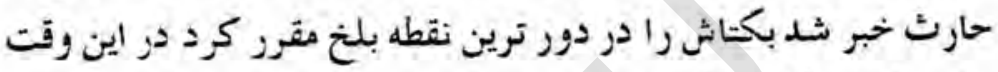

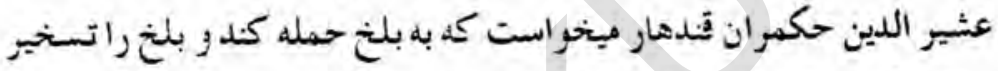

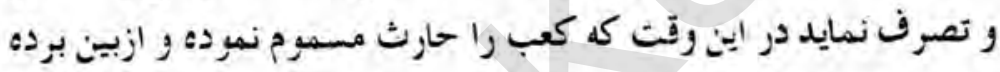

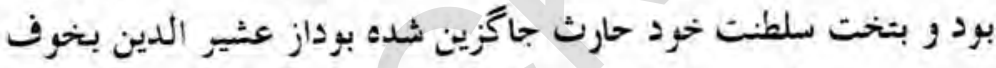

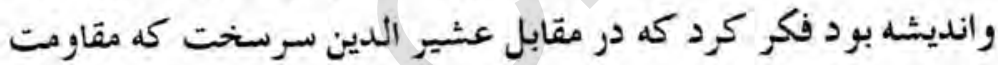

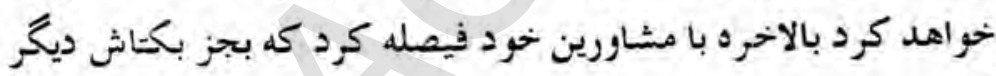

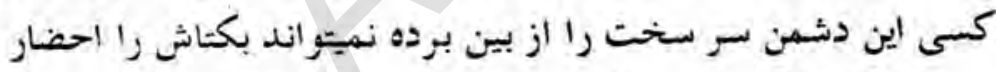

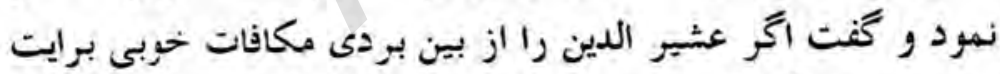

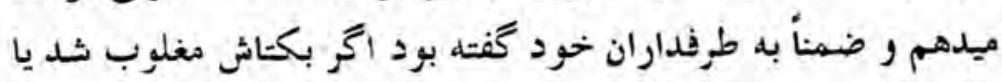

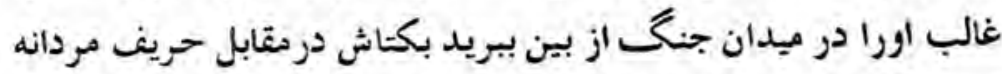

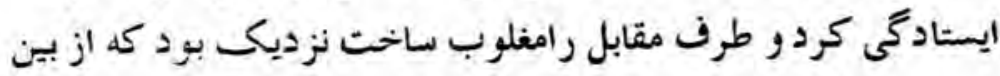
برود سوار كار زره بوش نقاب داردر ميدان در آمده بكتاش ران ازيديدان

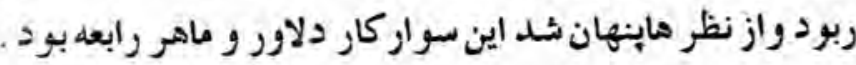

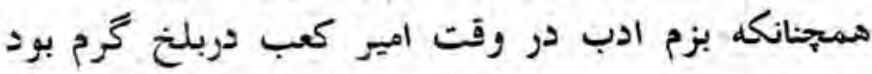

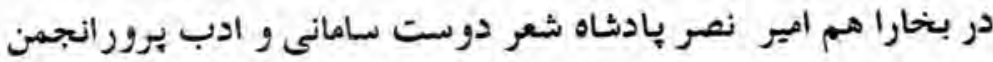

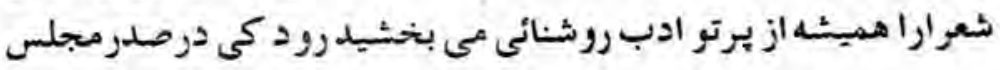


اي ميگرفت روزبكه مشاعره تاريخى دربخارا بر گذار شده بود حارث

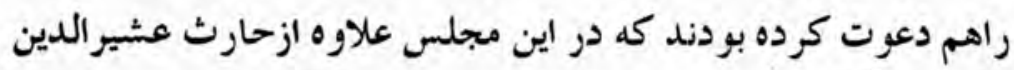

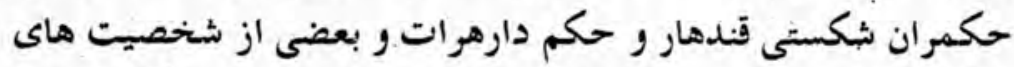

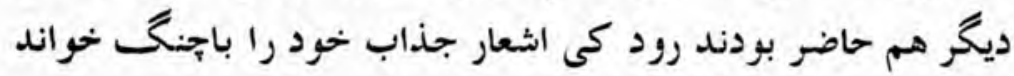

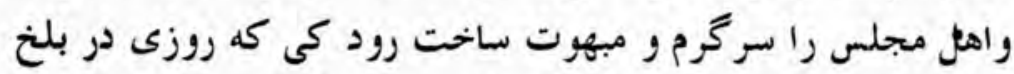
بارابعه مشاعره كرده بودو قدرت طبع او به رودكى مجى معلوم بوددوراين

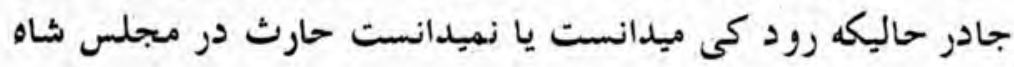

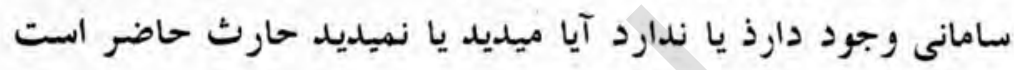

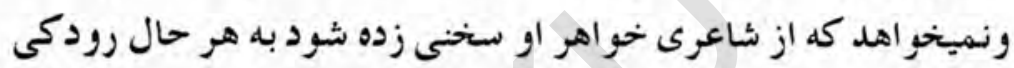

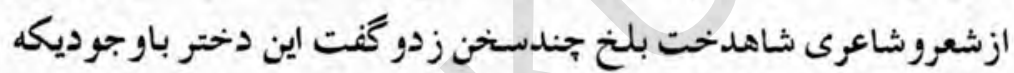

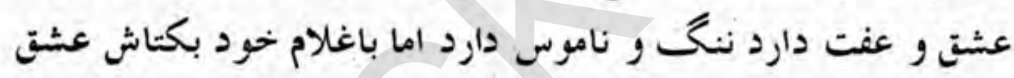

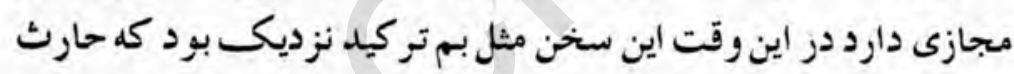

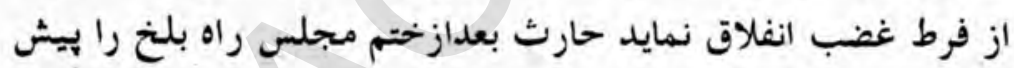

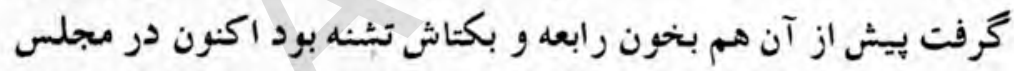
بزرق شاه سامانى اين سخن راشنيد كه رابعه و بكتاش ار تباط دارند

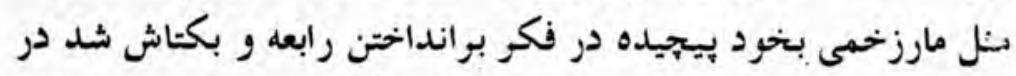

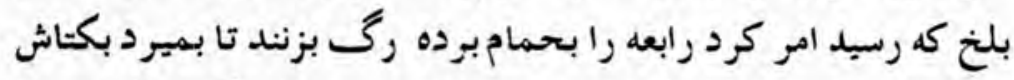

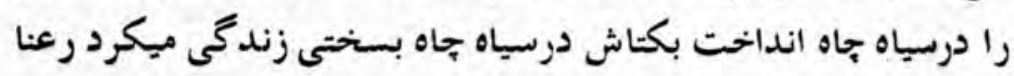

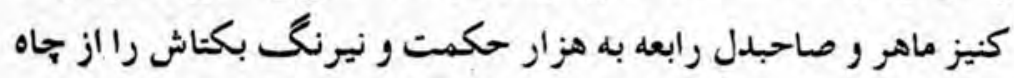

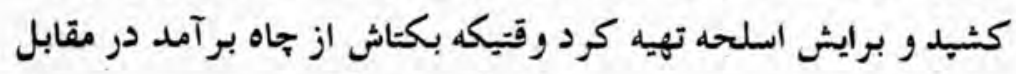

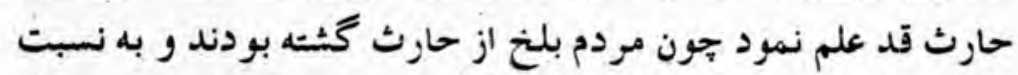

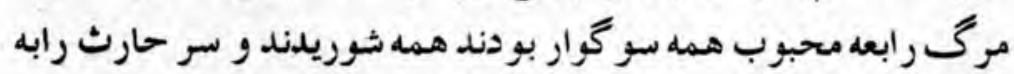

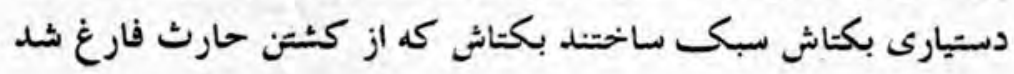


روبه حمام كرد وقتى بحمام ربيد وجود گرم و نازنين رابعه نسود ومجسـه شـده بود بكتاش در مقابل آن مجسـمه عشق و عفت آن آلهيه مكرم و مقدس زانو زد ديد كه الشعار خودرا باانكُشتان لطيف خورد در د يوار هاى يرنم و برغم حمام نويته و ور هو جاكلمه بكتاش نيز ديده

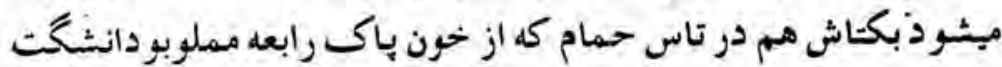

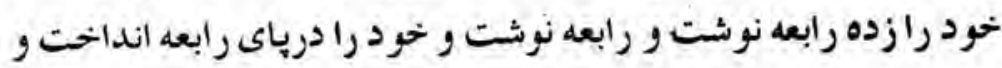
قربان نمرد هر دو جان را درراه عثئ باختيند.

\section{در اين كتاب سر كذشت خون آلود رابعه دُرج شده است}

درباب رابعه هر كس هو جيز نوتسته كرده است تا حال كتاب مفصلى درخصوص رابعه ديده نشده است يانز ده مسال ييش هنكاميكه در نوبهار

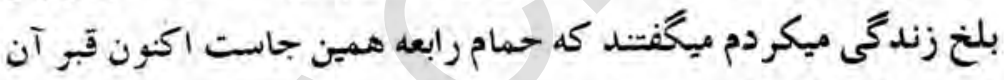
شهيد مظلوم كثيف شده الست بعضى رفقاى فاضل بلنى هـم در باب رابعه نوشته ونظريات داشته اند وقتّيكه دانستيل من در اين راه خيلى تحقيقات و تتبعات كرده ام همه نوشته هاى خودو را نزد خود نكه داشتيد اينك جلالتمآب صدقى اثٔر مراديدند وبسنديدند و موقع دادزله تاجاب

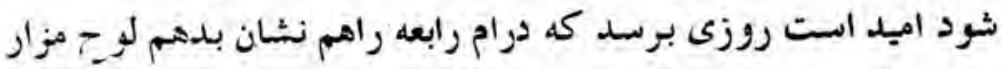
ومقبره آن دختر هردم شهيد نيز دوست شود و نام آن زنده و فرخند. كردد. رابعه رفت و اشعار رنكين و نسيده هاى شيرين وخرنين آن در حفحات تاريخ ادب ما جاودان ماند اكر جه اشعار آن كمتر بدسترس

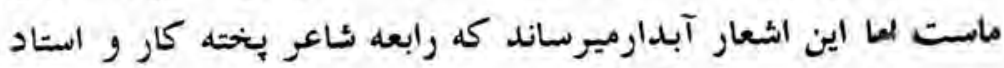
سنخ بوده كلمات برجسته و عالى آن نظيرو مانند ندارد اين كلهاى

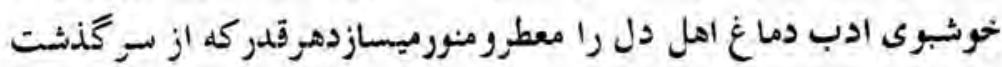





\section{تذكر و تشكر}

در طبع اين رساله كه جندسال منتظر جاب بود محترم كندهارى

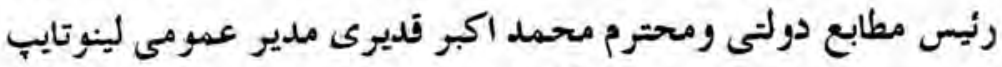

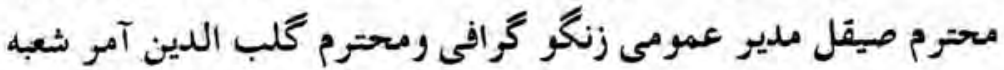

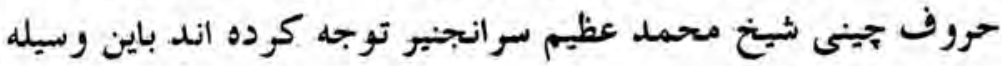

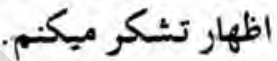

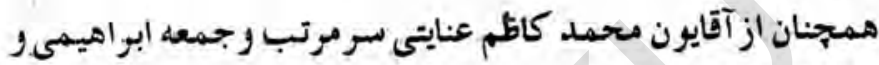

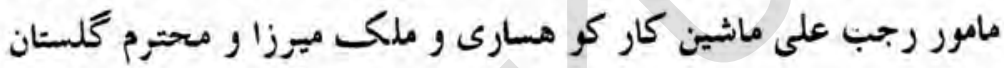

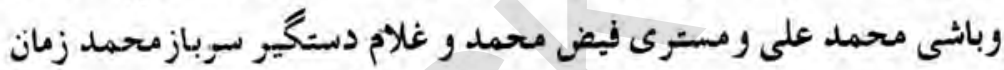

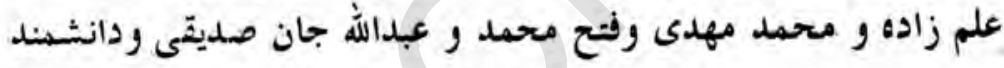

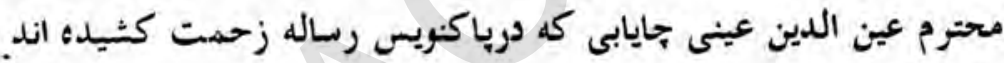

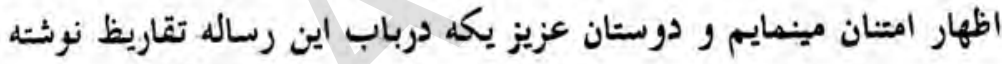

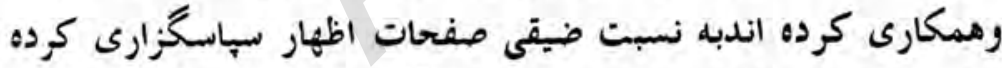

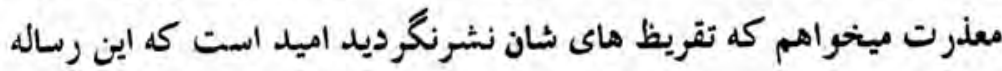

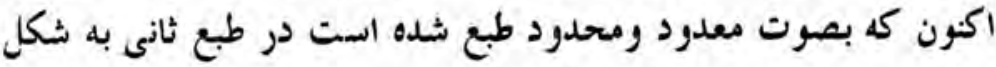
مرغوب تر ومطبوع تر جاب شده حق دوستان راخوبتر ادا كنيم.

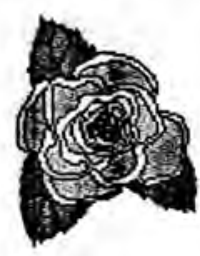




\section{رابعة بلخى}

بسكه خوبان در همين و يرانه هاتم گتثته اند

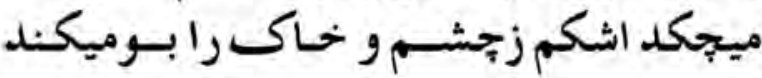

اكنونكه در گذر خير خواه ....مزار شريف ميباشمر ملدتى شده الست كه ازعالم مطبوعات دور هستم ، ولى قلب و قلمم بامطبوعات ميباشد

تازه از مزارات بلخ باز گثبته ام ، نوبهار و لنكرخاته سلطان

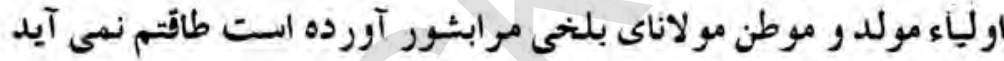

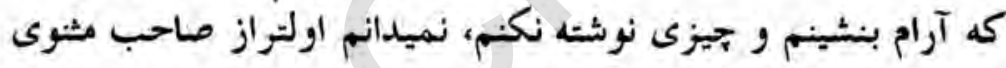

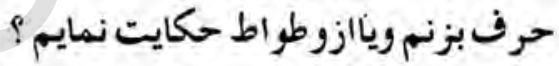

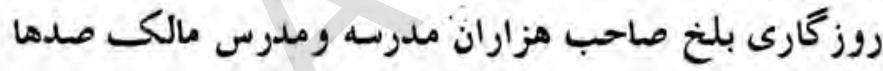

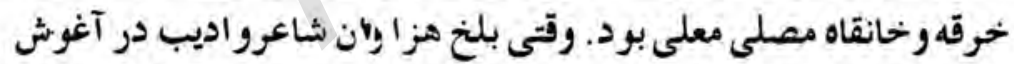

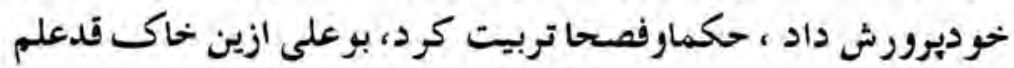

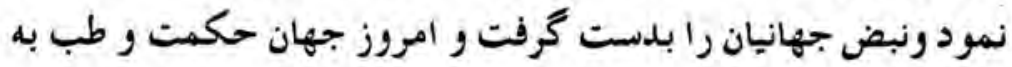

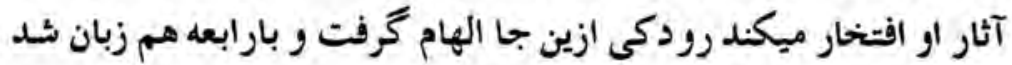

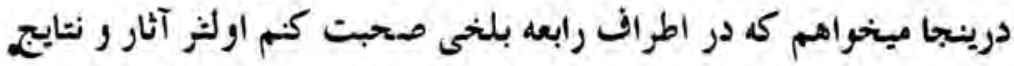

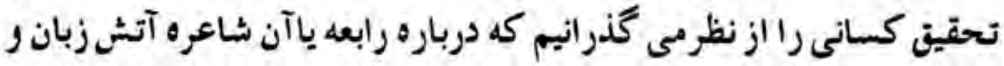

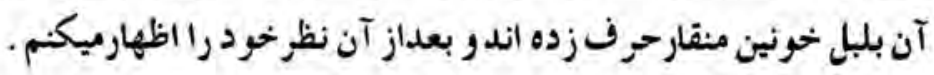

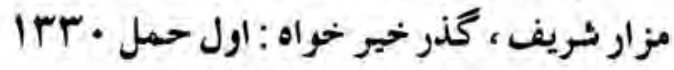
غ ع ع "نوابى" 
هذاميكه ياد داشتهاى خود را ترتيب ميكردم ، كتاب گلهاى

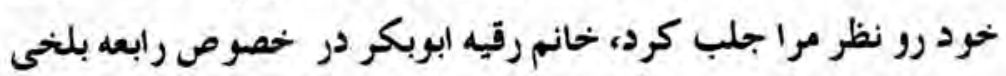
معلومات خود را جنين مينكارد:

جون غرض از دياد معلومات است بى مورد نخو اهد بود تا قبل

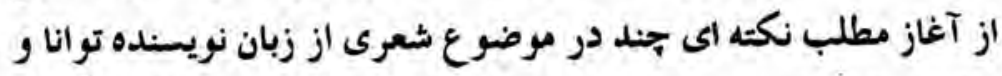
معاصر على دئى بعرض روسانم : علاوه بر فصاحت و بلاغتكه بيكمان

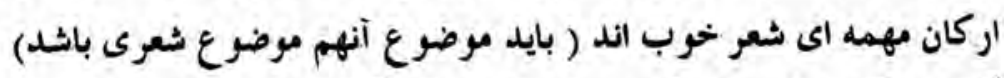

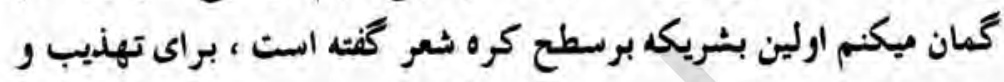

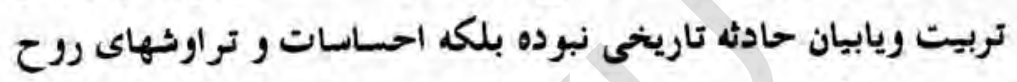

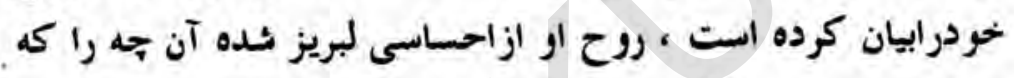

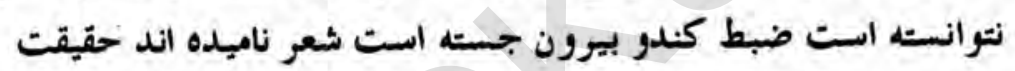

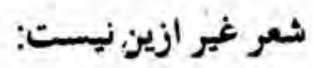

تخيلات زييا، روياهاى براز وجد وشوق ، احلام مملواز اندوه و

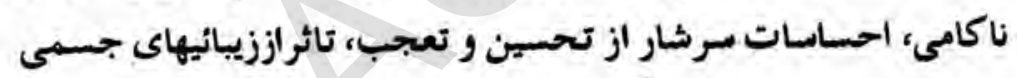

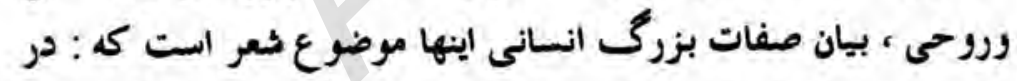

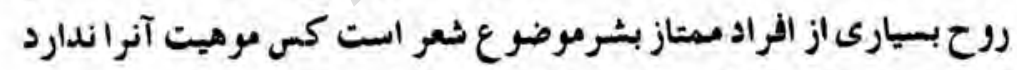

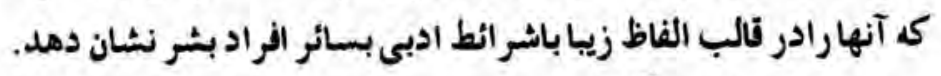

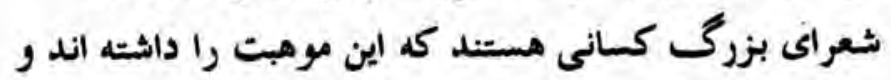

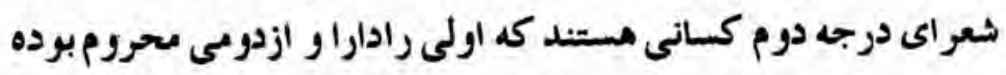

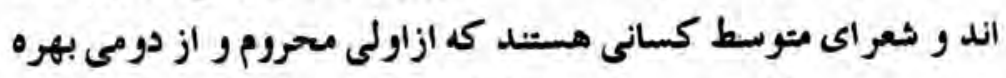

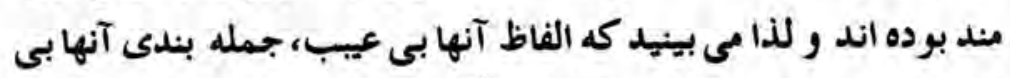

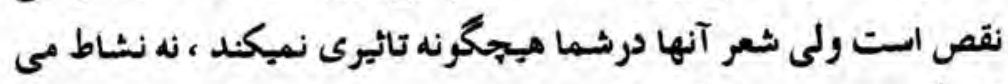

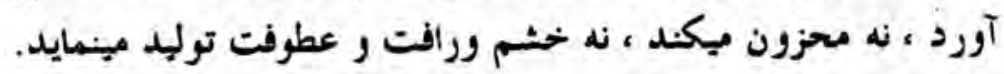


مارابعة بلنخى رامحض بدين جهت يكـ امتياز خاص مى بخشيم كه آن

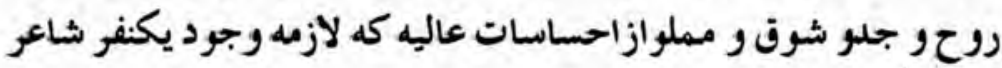
است در او جمع ودر موضوع جمال وزيبائى به منتها درجه حساس

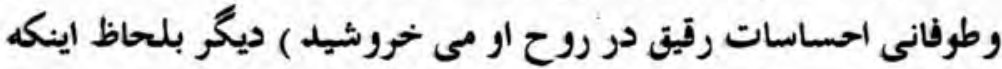

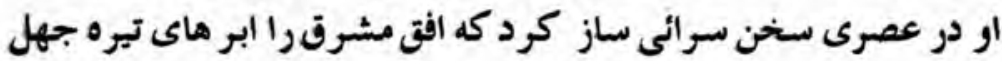

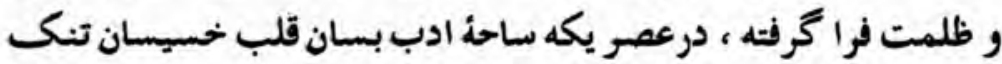

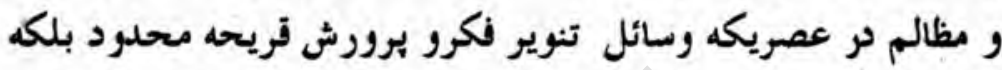

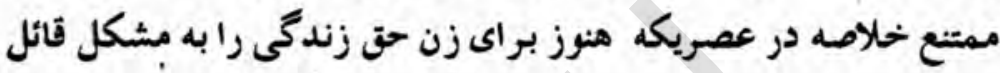

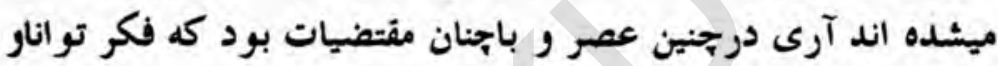

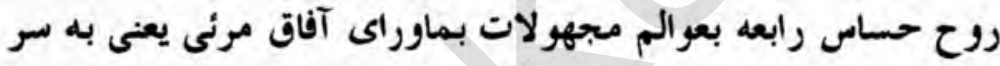

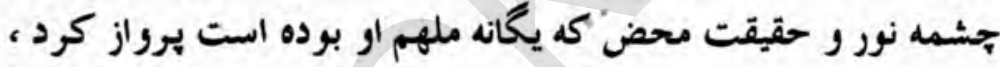

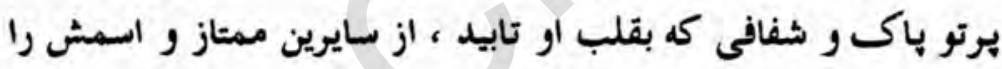
براى ابد در صفحه گيتى بئبت كرد.

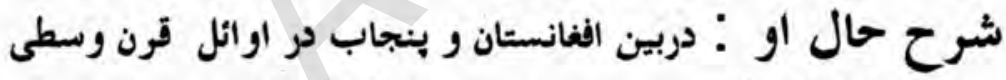

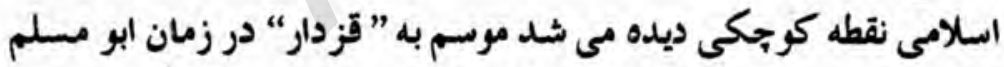

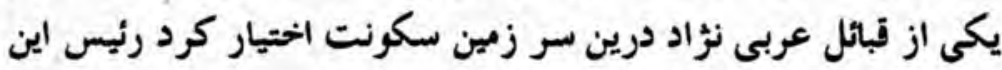

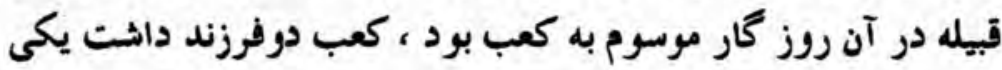
بسر بنام حارث و ديخرى دختر موسرم بله رابعه. ثرح حال وجگگنگى تحصيلات رابعه رابه تفصيل در هيج

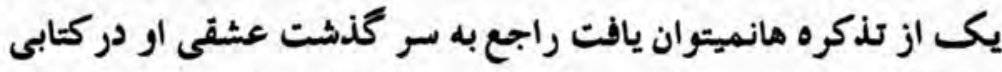

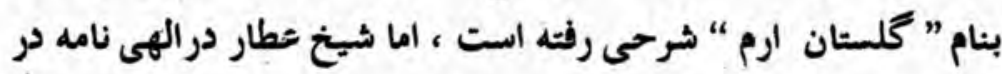
حلود بنجصد بيت راجع به شرح حال رابعه نوشته است كه مفاد آن آن 
كعب دردم مرگ بسرخود حارث رانزد خود خوانده گفت :

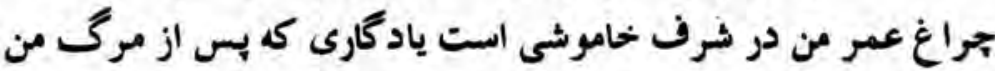
عزيزش ميدارى خواهر تو رابعه است زينهار كه از تربيت او غفلت نورزى و بدانى كه روح بزرگ در وجود او نهفته الست ، روزى تاج

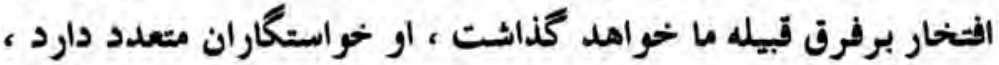
جوان فجاع و بافضل وهنرى برايش انتخاب كن بدان كه خوشى او

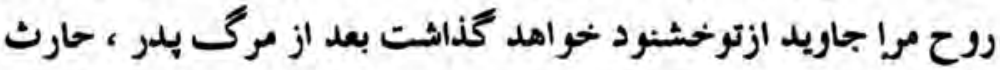
جانشين او و رئيس قبيله گرديد رابعه مانند گل و حشى كه ذر آغوش طبيعت نشورنما يالته و نسرانجام باجمال خيره كتنده بحدرشيد وكمال ميرسيل ولى برخلالف افراد عادى كه درين دوره جز نشاط وبيخيالى و خوشخذرانى كارى ندارند ، رو ح بر كث و حساس ، احساسات تند و ير مسر رابعه او را بكرثه كيرى سوق داده ويكثوع تحقير نسبت به محيط مبتل و عادى ايكه در آن ميزيست در خويشتن احساس ميكرد ، در صحراى بهناوروجود ، خود را تك و تنها من يافت دنيادر نظرش رونقى نداشت مثل اين بود كه زندكانى برايش رونقى ندارد ، بهار و خزان بيش جـسمش يكسان بود شبهاى مهتاب بيهوده برويش تبسم ميكرد ، ازتماشاى آسمان مجل و برستاره جيزى نهى فهميد آرى قلب بلدون عشق جامد و تسى ميشود ، مناعت و عزت از آن ميرود بـاى آن بوالهومسى ، هرزه جشمى وبالاخره خستخى مى آيد راتعاً ارواح حساس بزندكانى آرام و بى سر وحدا قانع نمى ثرند ، زندكانى بايد فرازو نشيهلها داثته باشـد ، هميشه بايديك طرفان در فضاى رو ح نعره بزند ) رابعه نيز درين دوره كه عملده ترين دوره هاى تول فكرى وموثر ترين وروه در باختمان ذهنيت افراد الـت دستخوش بهت و اضطراب 
باطنى او گرديد ، ولى بهمان اندازه اى كه بهت و حيرت او عميق بود

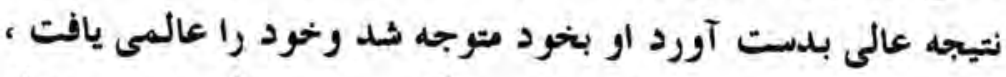

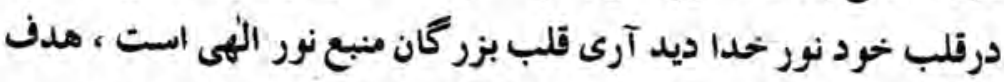

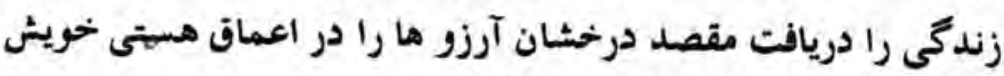

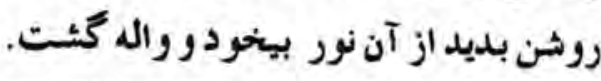

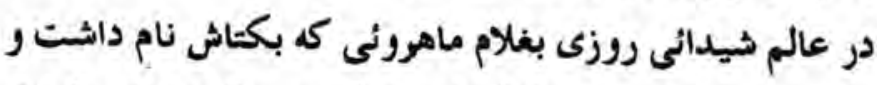

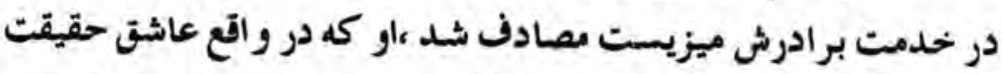

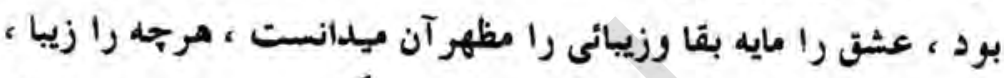

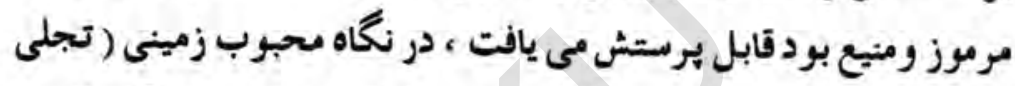

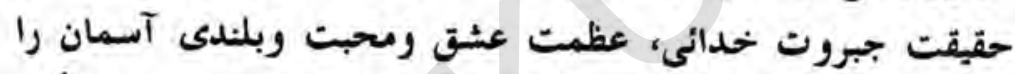

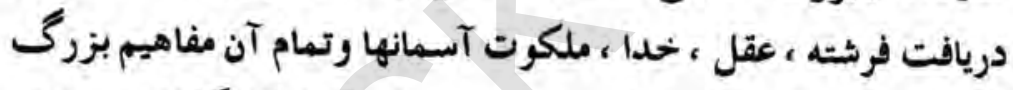

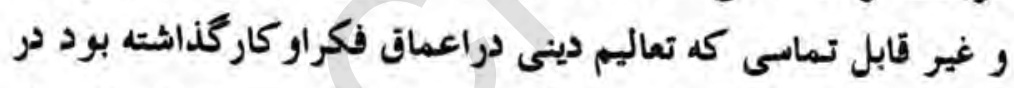

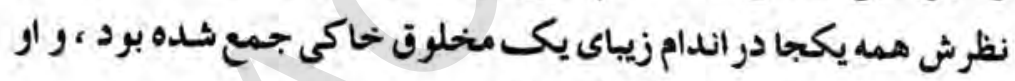
باتمام نيرو ار راستايش و تجليل ميكرد. درينجامعجزه عشق آشكار گرديد ، رابعه در شاعرى قدرت

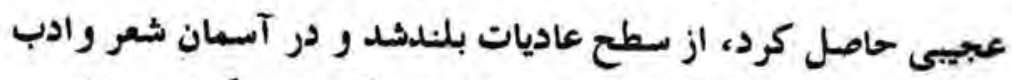

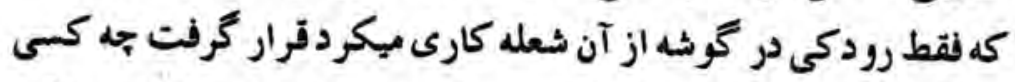

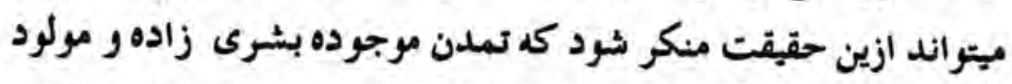

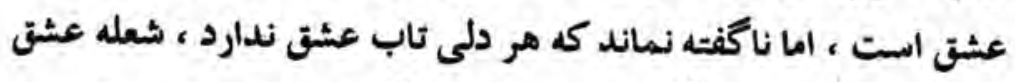
سوزنده ايست كه ميخدازد ر خحاكستر ميكند ( وجود رابعه همجيون

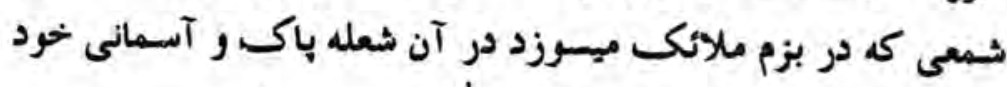
رامى سوخت جه خوش سرختى؟) 
رفته رفته رنجور شد و در بسترافتاد ، تواوشهاى روح درد ناكى

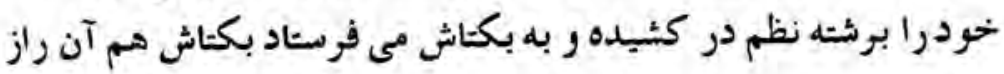

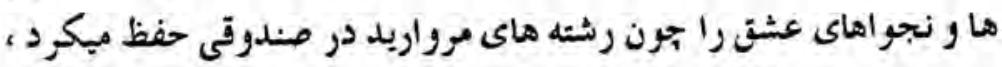

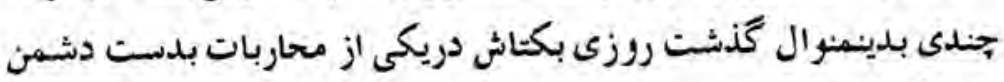

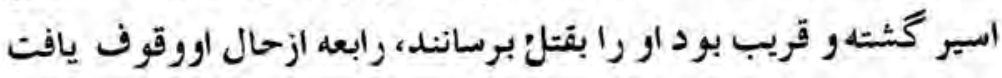

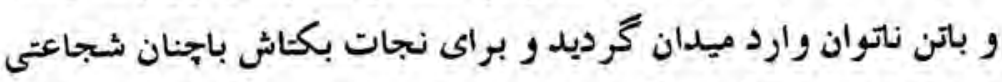

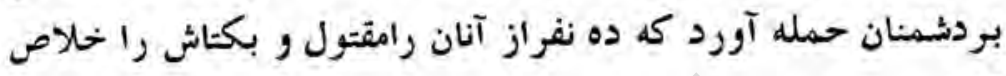
كرو.

حارث كه اورابانقاب نشناخته بود بخمان اينكه از زنان قبيله

است شخصى را بسر اغث فرستاد مكر ندانست كه رابعه بورد .

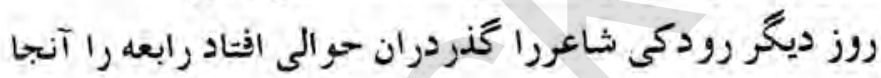

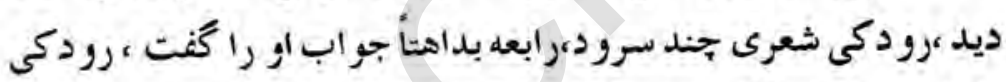

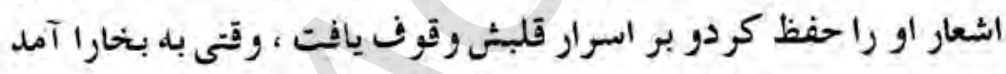

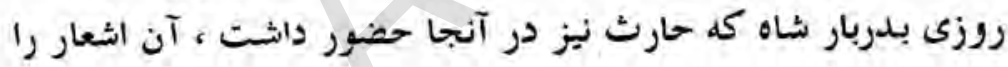

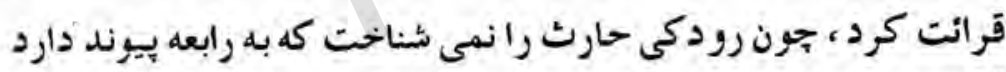

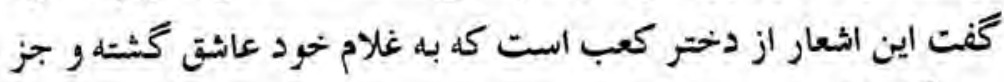
شعر كفتن كارى ندارد.

ازآن روزبه بعد سوء ظن حارث نسبت به رابعه قوى گثشت

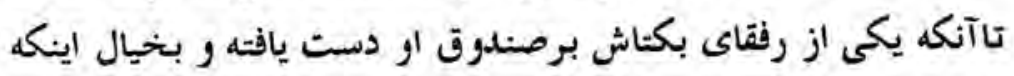

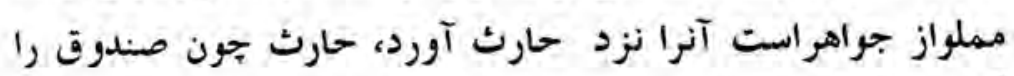

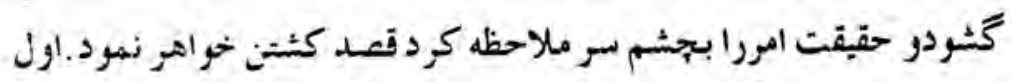

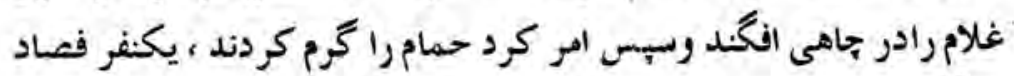

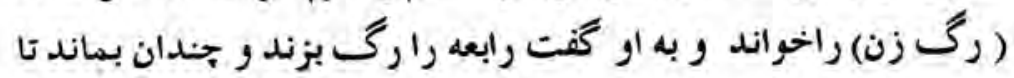


آخرين قطره خون از بدنش خارج شود ـ جنان كردند. وقتى آخرين قطره

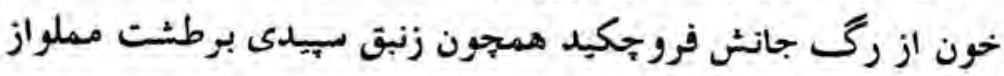
خون يثرمود.

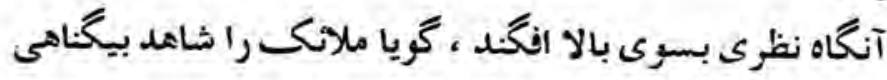

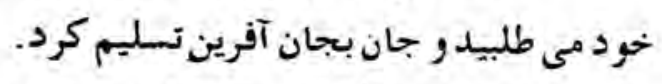

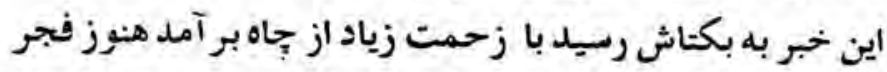

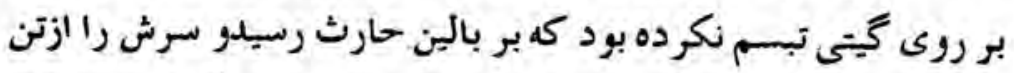

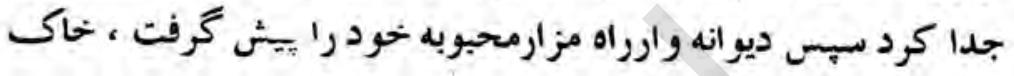

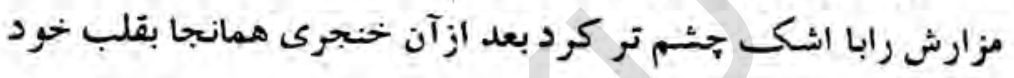
فرو بردو در كنار اوجان داد.

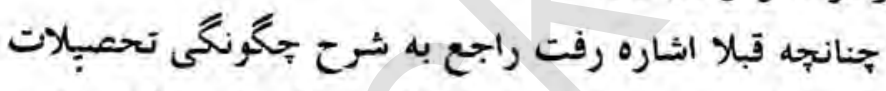
رابعه معلومات كافى بدست نيست ، اينقدر معلوم است كه معاصر

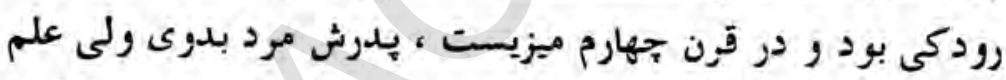

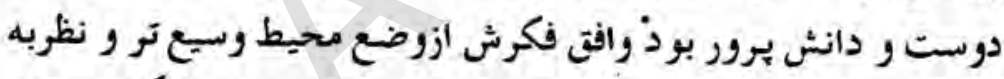

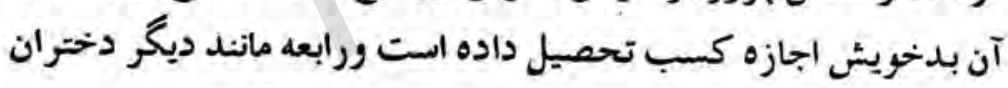

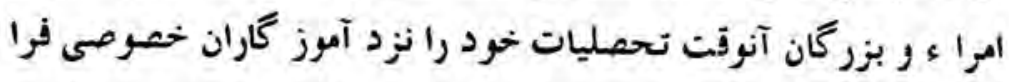

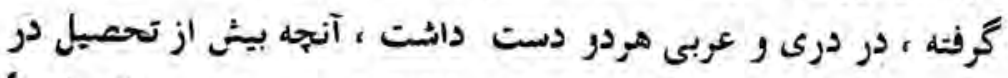

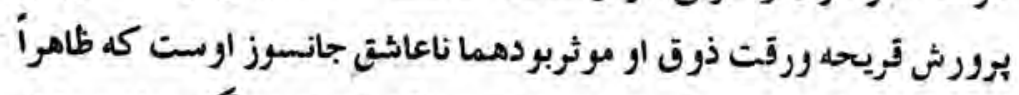
به بكتاش داشت ( در واقع همان عشقى بود كه شعر إى بزرئ بد بدان سرنياز

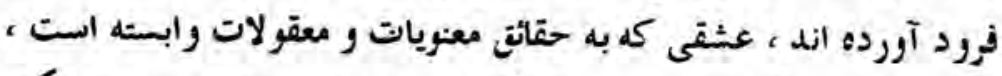

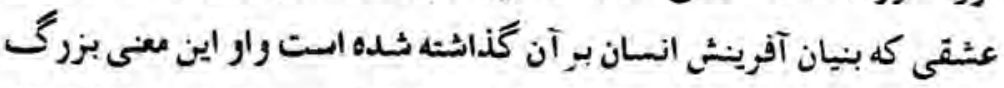

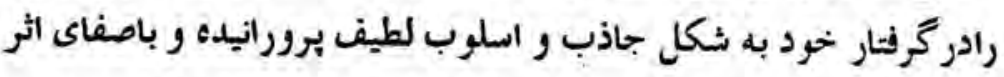

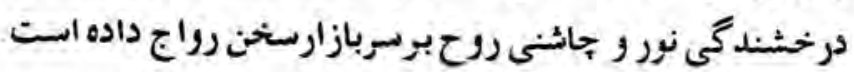


ازهمين جاست كه بزرگان اورا در رديف متصرفين قرار داده و

عشق او راعشت الهى خوانده اند.

جاى بسيار افسوس و و ندامت است كه آثار جنين شاعره

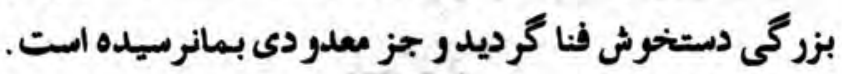

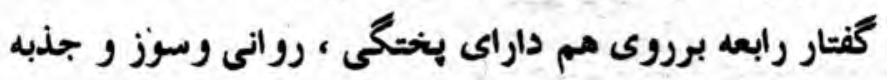

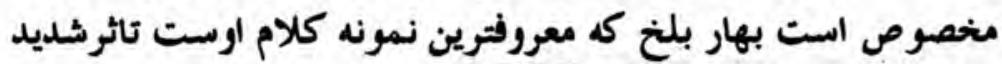

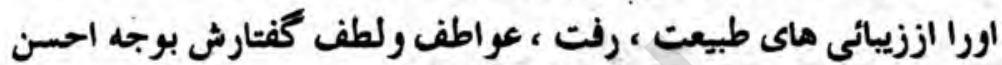

$$
\begin{aligned}
& \text { نمايندكى ميكند } \\
& \text { زبس گلز كهد درباغ ماوى گرفت } \\
& \text { جمن رنيح ار زنگ مانا گرفت }
\end{aligned}
$$

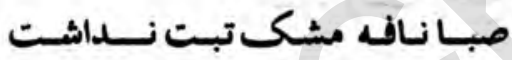

جهان بوى مشكـ ازجه معنى گرفت مثرن

$$
\begin{aligned}
& \text { مكر جشم مجنون بابر اندر است }
\end{aligned}
$$

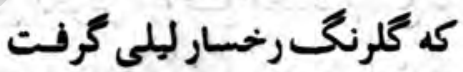

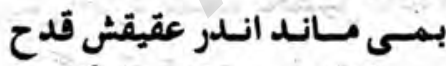

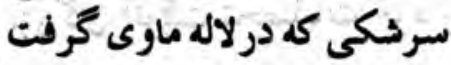

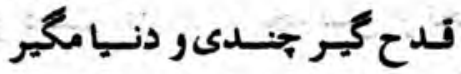

$$
\begin{aligned}
& \text { كه بلبخت شد آنكه دنيا ترفت }
\end{aligned}
$$

$$
\begin{aligned}
& \text { سـرنر تــس تـازه اززروسيم } \\
& \text { نشان سرتـاج كـــرى كرفت }
\end{aligned}
$$

$$
\begin{aligned}
& \text { جو رمبان مشداندر لباس كبود } \\
& \text { بنفـشه مكر دين ترما كرقت }
\end{aligned}
$$


جاى ديخررابعه به بيخناهى خود و طهارت و شفافيت عشق خويش الشاره كرده وازبـم فراف ناليده است واين مضسون را بـاســرز وتسائر عميق بيان ميكند.

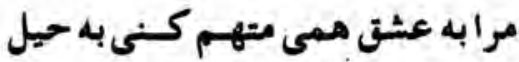

$$
\begin{aligned}
& \text { جه حجت آورى بيش حداي عزوجل }
\end{aligned}
$$

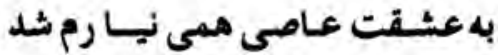

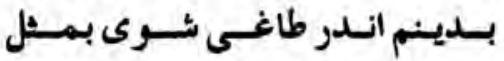

نعيـم بع تونخواهم جحيم با لـورواست

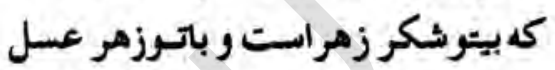

بورى نيكر تكيه مكن كه بايكـ جند

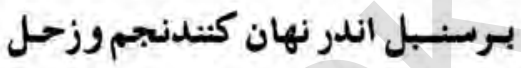

$$
\begin{aligned}
& \text { بر آينه نه دروغست آنهه گفت حكيم }
\end{aligned}
$$

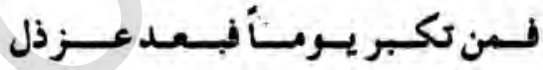

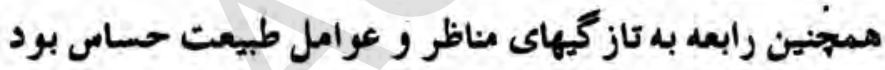

و جائى بايكـ ظرافت شاعر انه نسيم معطر بهارى راجين توحيف ميكند:

$$
\begin{aligned}
& \text { فشاند از سوسن رَّ بيم وزرباد } \\
& \text { زهـى بـادى كه رحمت باد برباد }
\end{aligned}
$$

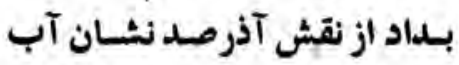

$$
\begin{aligned}
& \text { نمبرد ازسحر مانى صد ائر بـاد } \\
& \text { مشال جشم آدمشد مكر ابـر } \\
& \text { دليل لطف عيسي ثدمكرباد }
\end{aligned}
$$


كمه در بـاريسلد هـردم در جــمن ابــر

كل جان الزود خرش خوش در شجر باد

$$
\begin{aligned}
& \text { اكر ديسرانــه ابسر آمد جـرابس } \\
& \text { كند غصه صبوحى جام زر باد }
\end{aligned}
$$

كل خوش بوى ترسم آورد رنس

ازيسن غـماز صسبح بـرده در بـاد

$$
\begin{aligned}
& \text { بــراى جشـم هـــــا اهـلـ گوئى } \\
& \text { عروس باغ راتسد جـلـوه گرياد }
\end{aligned}
$$

عجب جون جسم خوشترميرود خراب

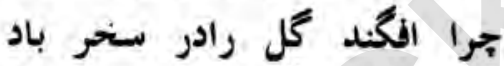

دردوبيتى زير رابعه سـزوخداز رابه اوج لطافت و گيرائى

ربسانيده و بالحن موثر وزنثدة از دردواندوه و ناكامى واستغناى معشبوق

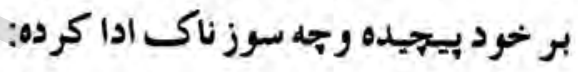

دعوت من برتو آن ثـد كايزدت عاشت كناد

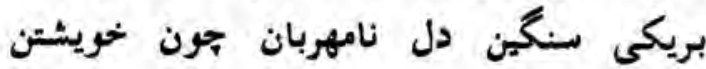

تابدانى درد عشت و داغ هجر وغم كثى

جون به عشتق اندر به بيحجى بس بدانى قدر من

***

در غزل زير قدرت عثتى و ضعف بشر رادر مقابل اين عاطفه

نيرومند بطرزى بيان ميدارد كه انسان از سلطه عشق بر قلمرو قلب او

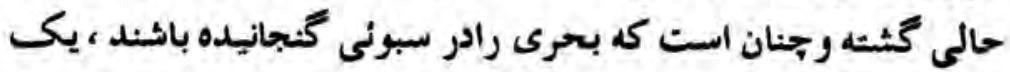
دنيا شوريدگى و تهش وهيجان را در جيد شعر مختصبر ادا كرده است 
واز وراي همين مختصر سبك متين شيوه استرار شيواثى بلان ار مشهود

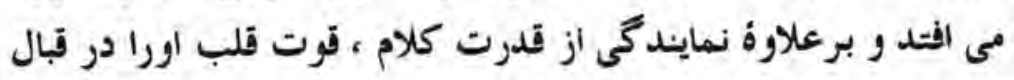

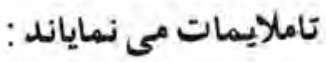

$$
\text { كوثشّ او باز اندر آوردم به بند }
$$

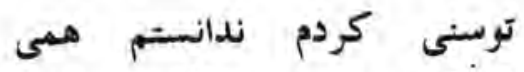
كز كثيدن سخت تر كر دو كمند

$$
\begin{aligned}
& \text { عشّق دريائى كرانه نـا بــديد } \\
& \text { كى توان كردن شنا الى مستمند }
\end{aligned}
$$

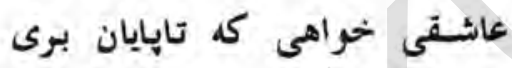

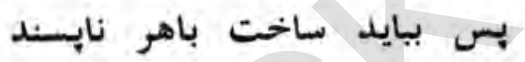

$$
\begin{aligned}
& \text { زثتت بايد ديدوانكاريد خوب يبايد } \\
& \text { زهر بايد خوردو بنداريد قند بند }
\end{aligned}
$$

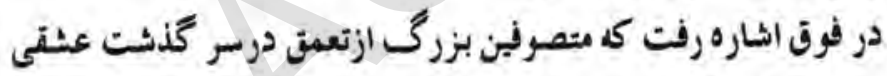

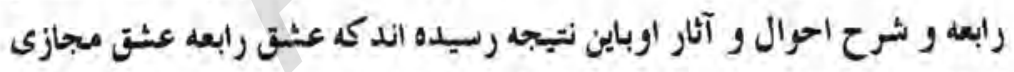

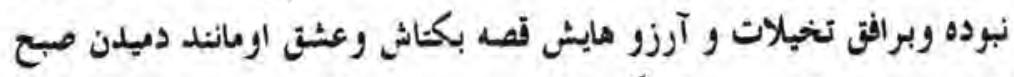

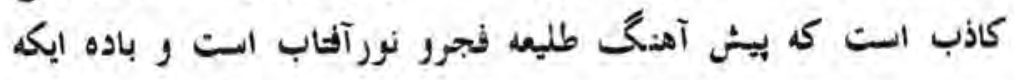

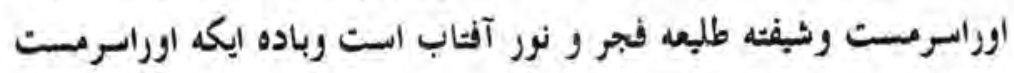

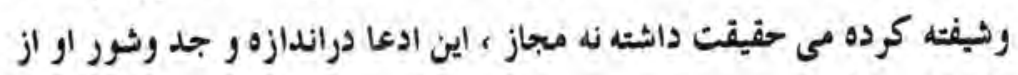

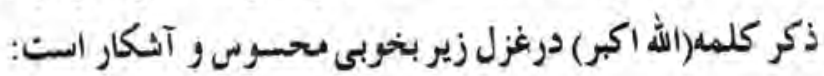
* * *

$$
\begin{aligned}
& \text { الا اي بادشبحيرى بيام من بلدلبر بر } 1
\end{aligned}
$$

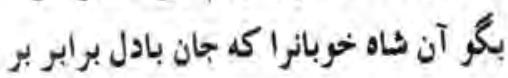


بقهراز من لخندى دل بيكس ديلدار مهرويا!

جنان جون حهلر كرار درآن حصن خهير بر دير

توجون مامى و من مـاهى مبى سوزم بثابه بر

غم عشقت نه بس باشلد جفا بنهادى از بربر مئر

تنم جون جنبرى گثنت بدان اميد تاروزى بندي

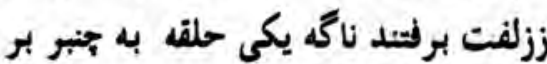

$$
\text { كه هرگز مسر گتشه معشرق ومس غم زين قبيل دارم }
$$

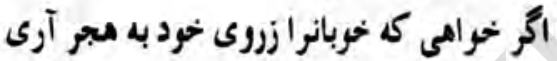

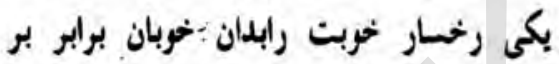

ايامثرذن تو براحوال عاشت گر نظر دارى

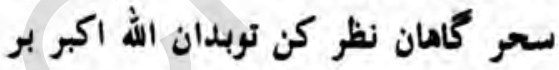

مداراى "بنت كعب" انده كه با راز توجداماند

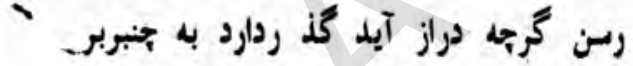

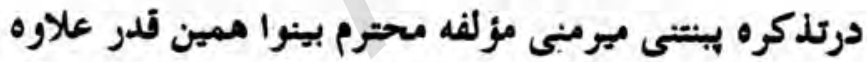

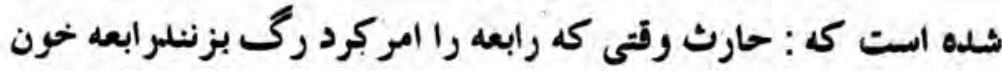

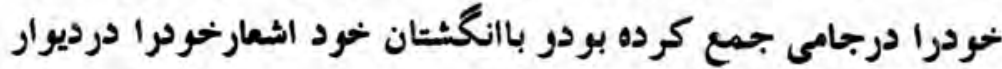
هاى حمام مينوشت .

بخفته شايت جمال: "خوش آن شاعر كه بنويسـد بخون خويش ديوان راه"، *** 
شبلى نعمانى در شعر العجم مينويسد:

واين يكى ازاختصاصات عمبرسامانى بوده كه ذوق شعر العبر

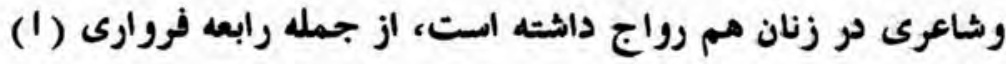

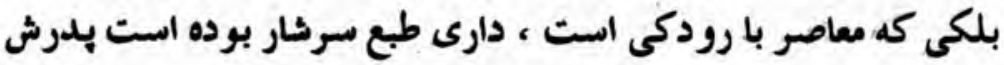

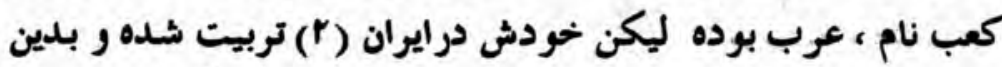

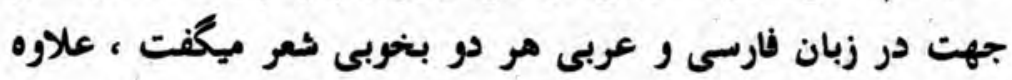

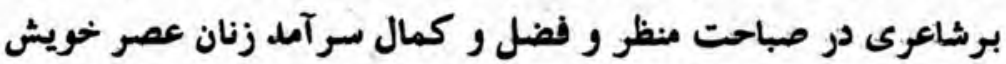

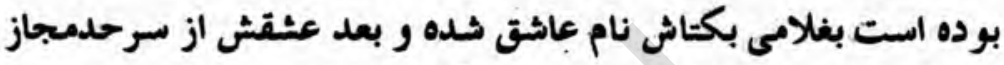

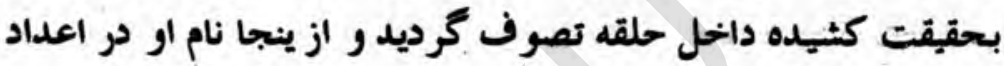
صوفيه بشسار آمده است.

ولى باين حال جون ارتباط يكنفر زن بامرد اجنبى در جامعه امده

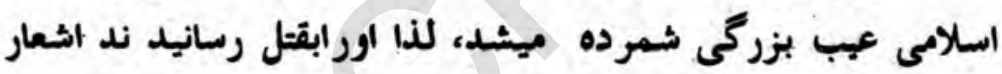
زيادى از او درمجمع الفصحا مذكور واز جمله دو بيت ذيل است : دعوت من بر تو آن شد كايزدت عاشق كناد

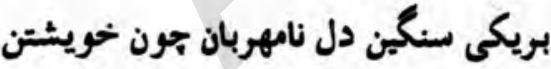

$$
\text { تابدانى درد عشق و داغ هجر و غم كشى بنى }
$$

جوز به هجرا ندربه بيسجى بس بدانى قدر من

\section{*** *}

اين جند سطر از جلد اول شعر العجم كه ذريعه سيد محمد تقى

(1) (1) اصلغ تزمراى است با تنغق تعام تذكره نوسيلن.

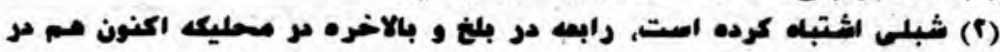

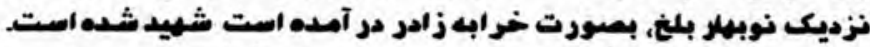
عنوابى 
فخر داعى كيلانى ترجمه شـده امت اقباس كرديد *** *

درجلد اول " تذكره زنان سخنوره" درباب رابعه آقاى

عبدالرحمن فراموزى مينويسـد:

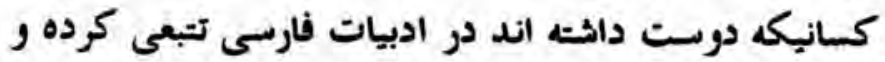

كويند گانى را كه ابتدا شروع بسرو دن شعر فارسى نمرده اند بشناسند ، طبعا درورق زدن كمب تذكره بنام رابعه قزدارى بر خحر ده و درشان عشق او

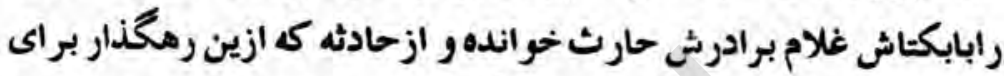
دختر دانشسمدى خوثن فريحه و شيرين سنخ مانتد او رخ داده است غمكين كثته و قطره اثكى بياد او ريخته اند درآن روز هائيكه در كوشه و كناراين كشور, الشخاص شروع بكفتن شعر فارسى كرده بودند از انجمله رود كى در دربار بادهاهان سامانى بدستان زنى مشيخول بود و بوامطه بـتخرانى خويش مررداحترام و انعام امرا و بزرگان قرار ميكرفت در يكى از گرشه ماى دور دمت يعنى در قزدار در حرمسراى يكى از بزركان آنجا دخترى سازد ستانسرائى راساز كرده و نواى

$$
\text { دلكث او از بشت برده باطر افو نوراتى ميرسيد }
$$

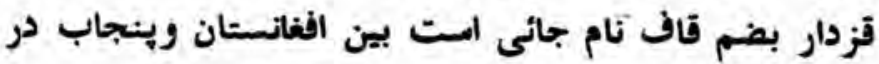

حدود هزار مسال يُش ازين يكى از قبيله هاى تازى نؤاد در آنا ميزيست كه باختلاف فصرل مال ميان آنجا وبست وفندهار بلخ و ميستان ييلاق

وقشلاق ميكرد و آنرارئيسى بود كعب نام كه بادشاهان سامانى او را محترم شمرده و زين العرب ميخوانلند اين فيله درجه تاريخى بدانجا

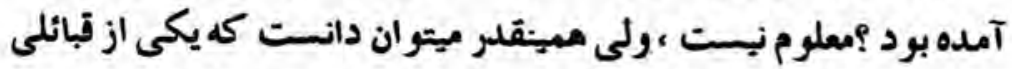
بوده كه خلفاى عرب بقصد تشكيل كرلونى هاى عرب بكثبور ایى فتح 
شده كوج ميدادند ، بهر حال كعب (زين العرب) ) در حذشت و از وى دو

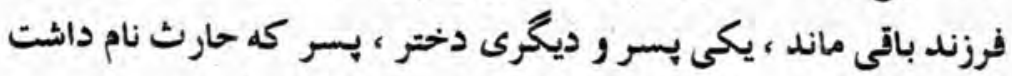

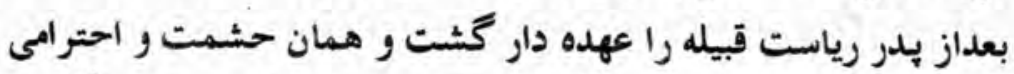

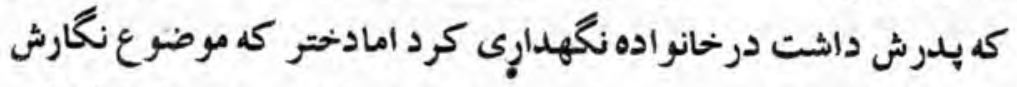

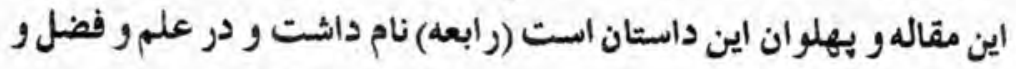
بلاغت به بايه بلندى رسيد درجه مكتبى و نزد كدام استادى درس

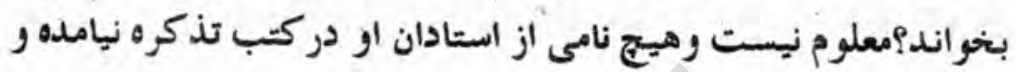

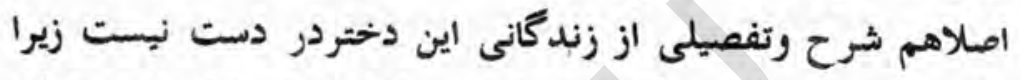

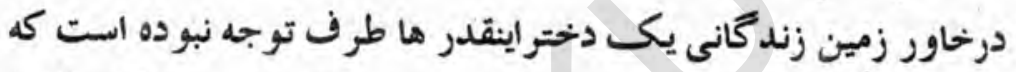

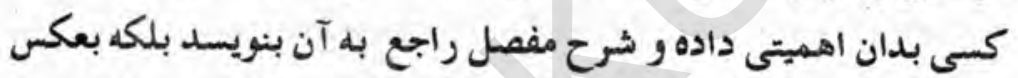

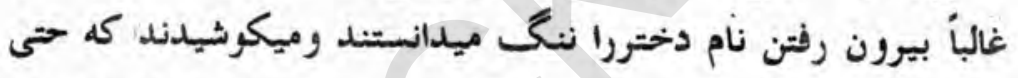
الامكان خود ونامش در خانه محفوظ ور مستور بماند قبيله ويدر او

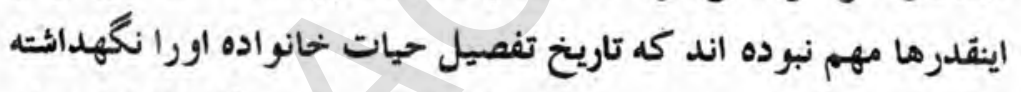
باشد ، زيراباز در مشرق زمين كمتراتفاق افتاده است كه تاريخ نويسان

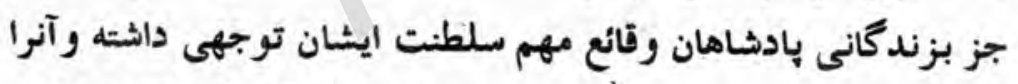

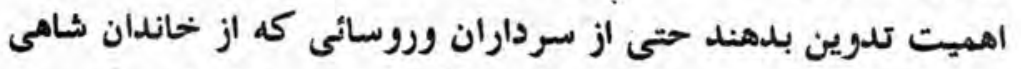

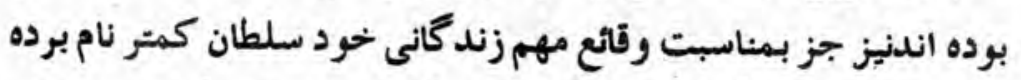

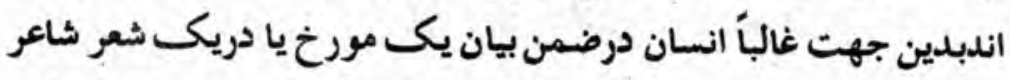

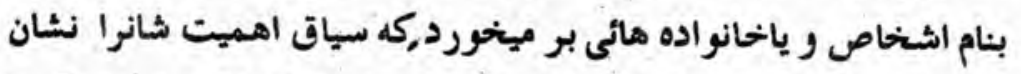

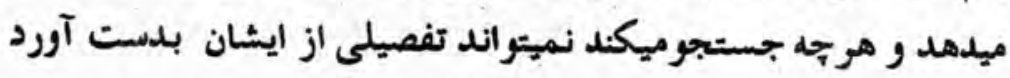

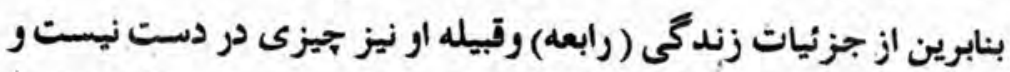

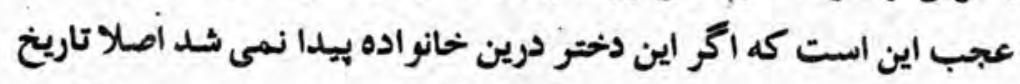

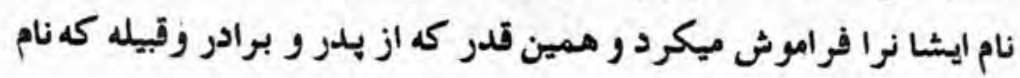


برده ميشبود نيز بواسطه اين دختر است.

درهرصورت شكى نيست كه تحميلات رابعه مثل سائر

دختران بزر گان و اميران درخانه و نزدامتادان خصوصى بوده و اين خود نشان ميدهد كه بـرش با ايثكه رئيس ايل و جادر نشين بوده خحرد فضل و دانشى داشته كه قيميت دانش را ميدانسته و در آن زمان دختر خود را اينطور بافضل و كمال بار آورده است رابعه از كسانى است كه در تاسيس كاخ ادبيات فارسى شركت داثته است ، الشعار او بسيار شيرين و دليذير است ولى متاسفانه جيز زيادى از آنها باقى نمانده است. خوب و صف ميكند ، بسيار ناز كـ خيال و غزلش شيرين و روان برور است ، بسناسبت نزاد ور اقامتكاه و نيز بمناسبت تحصيلات

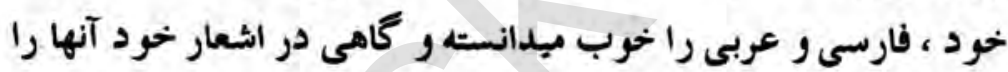
بهم آميخته و بسيار شيرين ساخته امست مثل اين شعر : شاقنى مانم

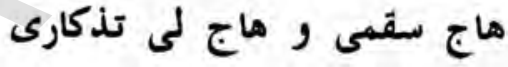
دوش برشاخكـ در خت آن مرغ هن

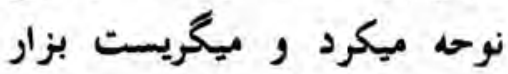

قلت للطير الم تنوح و تبكى

فى دجى الليل و النجوم در ار

من جدايم زيار از آن نالم توجه نالى كه بامساعد يار

من نظويم جو خون ديده بيار توجه كوئى جو خون ديده نبار 
بارى حارث برادر رابعه را غلامى بود بكتاش نام و ترك كه

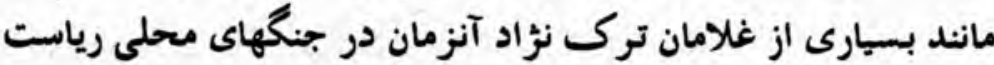

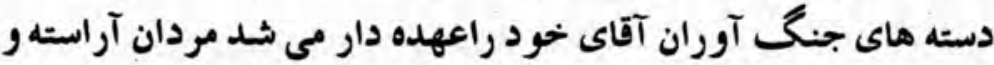

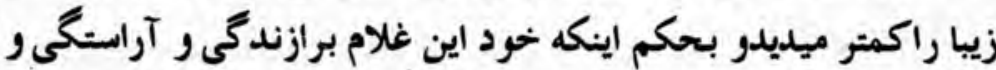

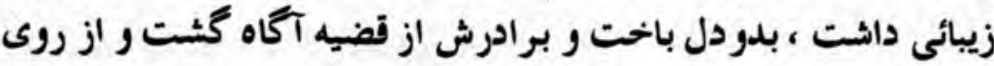

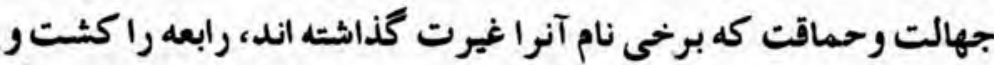

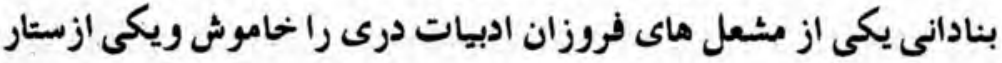

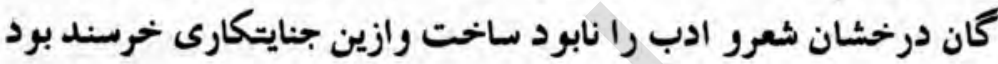
وبدتر آنكه اين برادر جنايتكار از عشق خواهر خود تفصيلى نميدانست

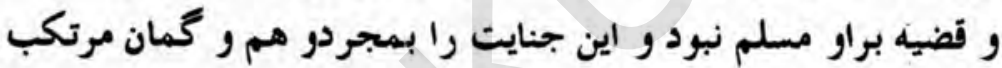
كرديد.

مو لانا جامى (رح) در كتاب نفحات الانس رابعه را جز و عشاق حقيقى و از رسيدكان راه يعنى اولياء الله نام برده ور ويرا جزء بـان عرفاى بزرگق شمرده امست. شيخ عطار (رح) نيز مجملى از حالات اين دختر رانظم كردهو و وازين ييداست كه رابعه نزد عرفا مقام بلندى دارد دئ.

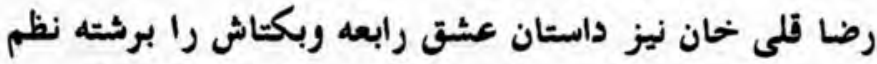

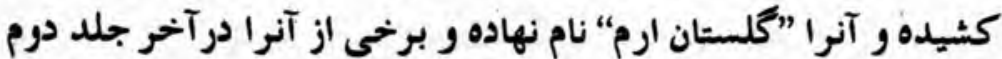
مجمع الفصحا جاب كرده است. آقاى رضا ايزدى همدانى ليسانسه دانشكده ادبيات تهران

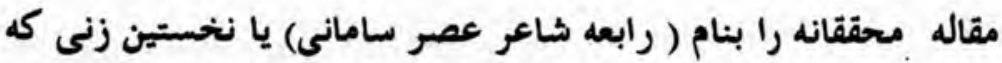

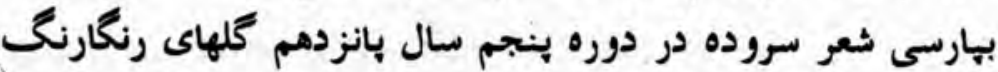
نوشته كه خلاصه آن اين است : 
سـده جهارم هجرى هميثـه مانـد ستاره درخشانى در بيشانى

$$
\text { سلده هاى تاريخ با فروشكوه برتو فشانى كرده است: }
$$

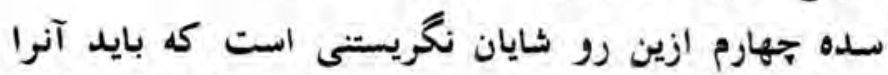

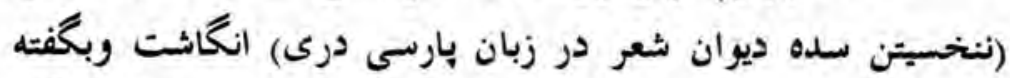
دانشـمند كر انهايه شبلى نعمانى صاحب كتاب شعر العجم ور آثار ديكر اين خصوحيت درين سله است كه زنان هم همدوش مردان در ساختن و بايه گذاشتن كاخ شعرو ادب دست داشته اند ، زيرا درين زمان بودكه زنى براي نخستين بار ببارسى شعر كفت و او رابعه دختر كعب بود كه

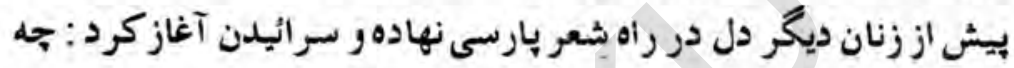
بيش از وزنى بزبان بارسى شعر نكفته بود شبلى نعمانى در شعر العجم نام رابعه را در شمار سخنوران زمان خاندان سامانى يادكرده ولى بهتر از همه شيخ فريد الدين عطار

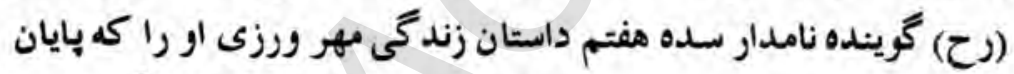

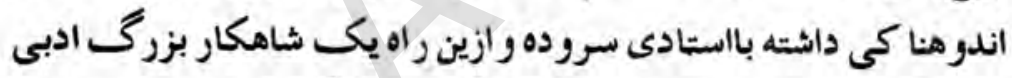
بديد آورده است بيش ازين ها كه كذنشت ديكر از رابعه بيزى در دست نيسـت تر انه هايش بسيار اندك ولى همه گيرنده و روان واسترار و دلنشين است آنجنان كه بيداست بيــر اشعار رابعه در زمانى سرورده شده كه سرگرم مهر ورزى ودلباختى بابكتاش غلام زيبا روى بوده

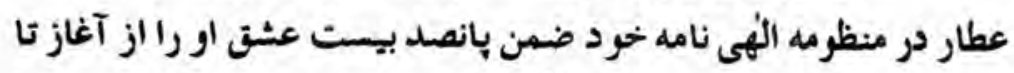

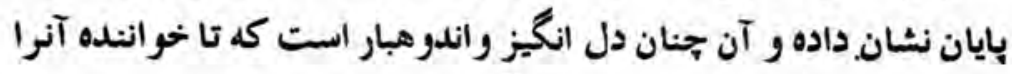
به بايان نوساند دل از خواندن برنكيرد رابعه با سر آغاز بسيار ساده

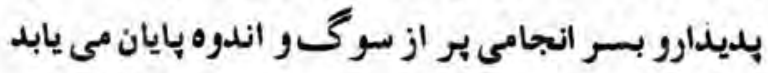

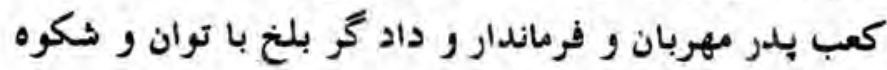


بسيار فرمانروائى داشتـ ، ازيرتو دادو توانائى او سرزمين بلخ در

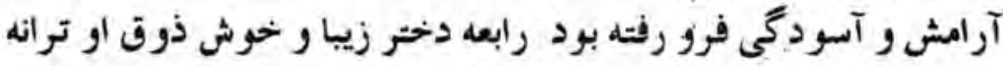

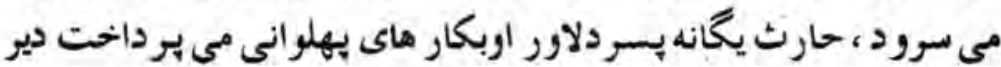

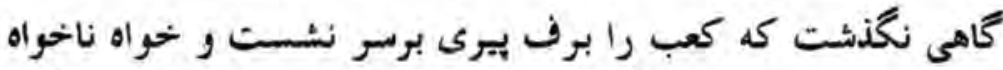

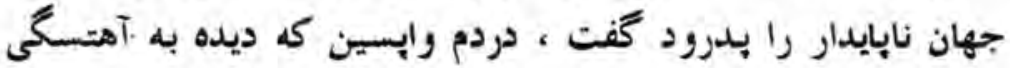

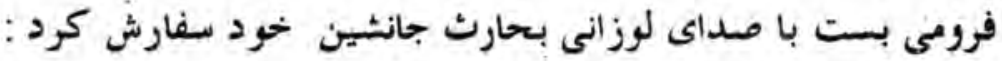

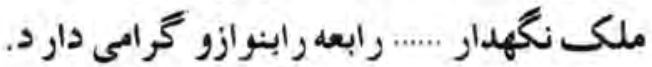

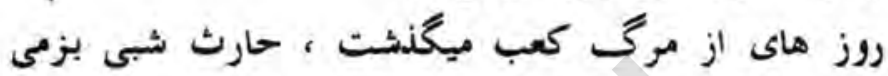
بياراست زنان وئه غلامان ، كنيزان و همدمان درين بزم انباز و دسترور

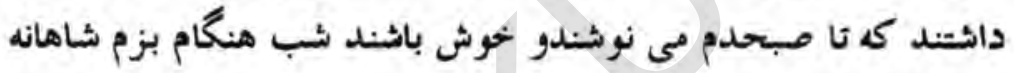

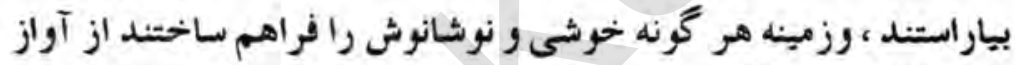

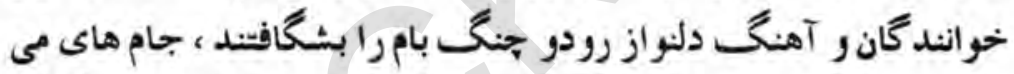

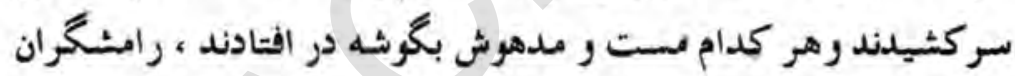
مى رقصيدند غلامان با مهرويان راز مى كَّتيد درين ميان بكتاش غلام زيبا روى مشكين موى همان فيان غلام ويلام وبره

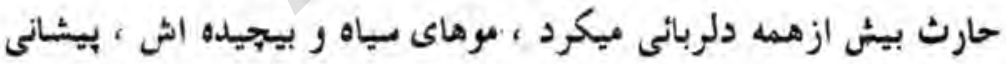

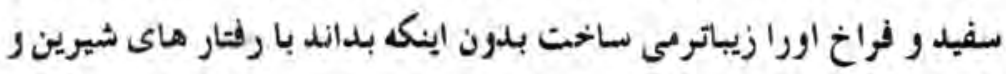

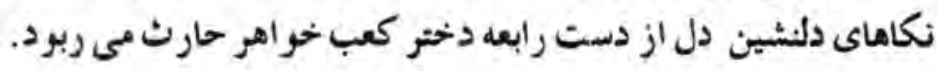

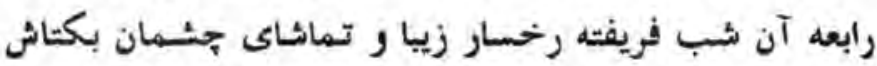

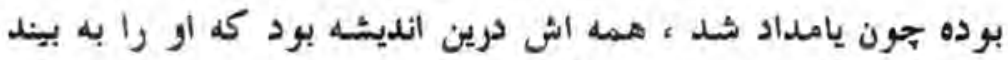

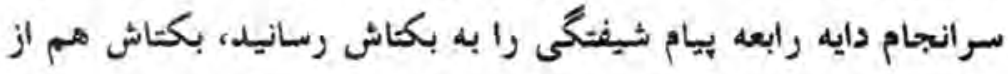

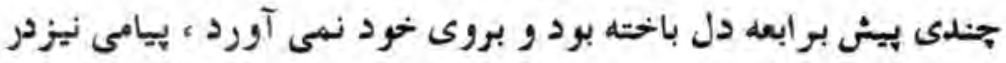

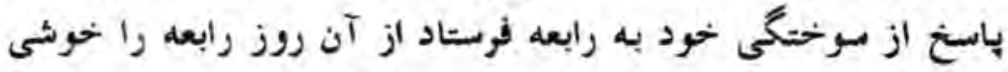


r.

رابعة بلفى

رشادى ديخر بود ، باميد ربسيدن بدلداده خود باين مهر و دلبستى كه

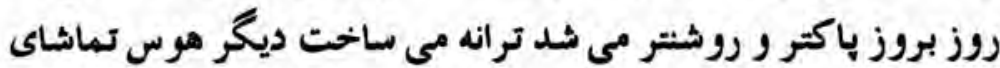

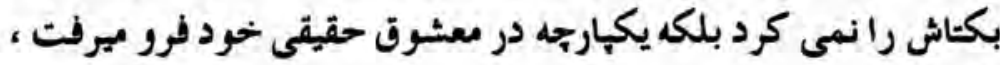

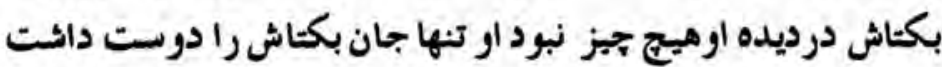

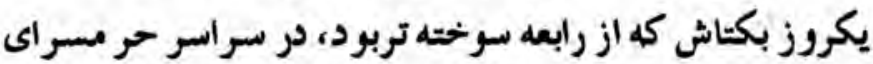

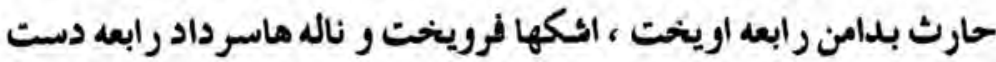

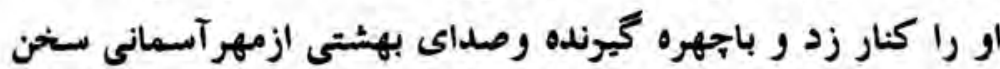

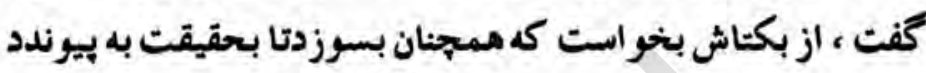

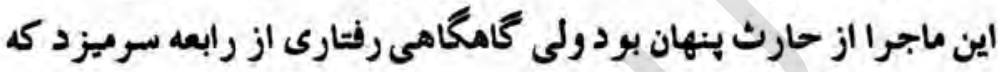

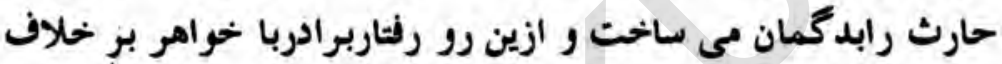

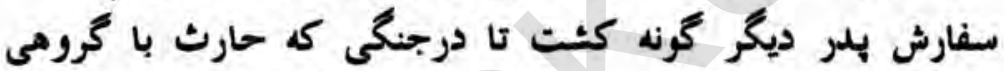

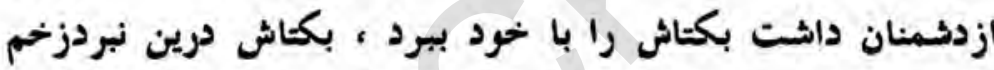

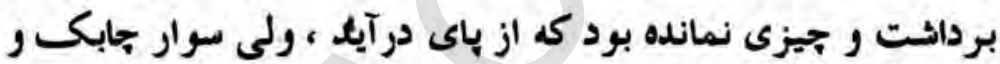

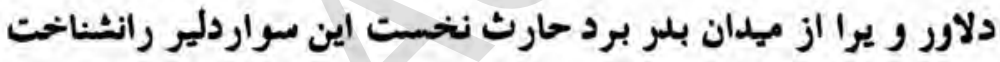

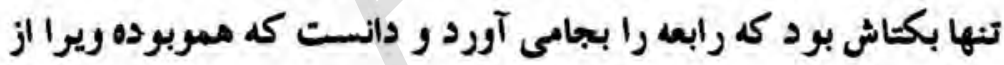

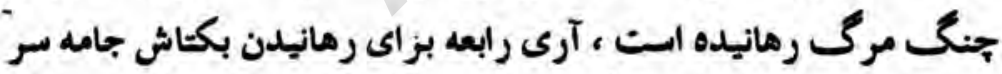

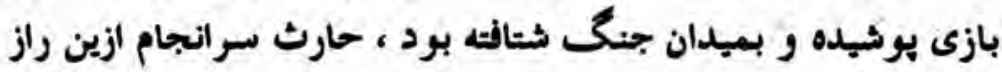

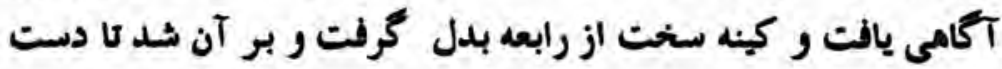
آريزى بيدا كند رابعه از ممه جاى خبر بود ، شب تاسهيده دم نمى خفت ناله ماى كردو ورازمى كخت روزى رودكى گگينده نامى رابعه رابديد وتر انه ها بخو اند رابعه

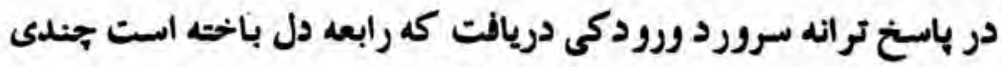

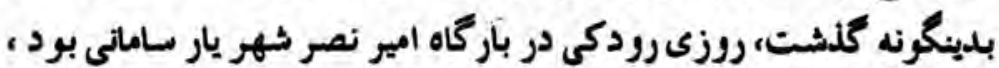


شاه از او خواست كه شعر بخو اند ، رود كى ازتر انه هاى رابعه بخواندو

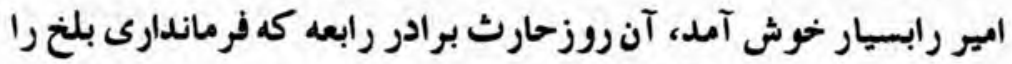
داشت در آنجا بود رودكى باز الشعارى خواند و بايان از رابعه نام برد

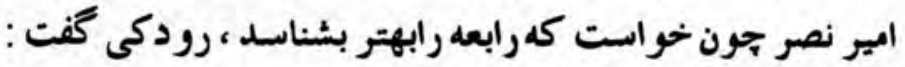

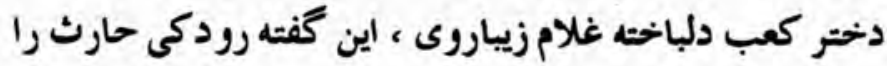

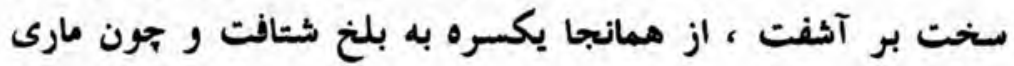

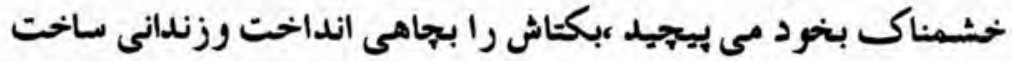

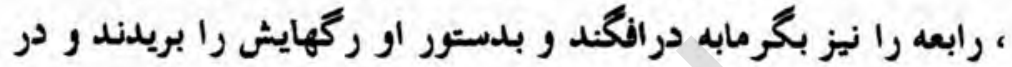

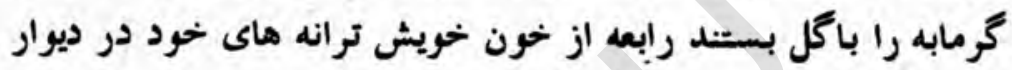

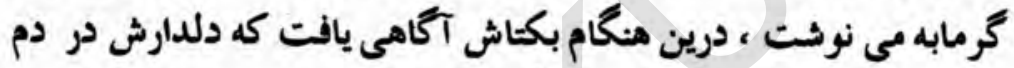

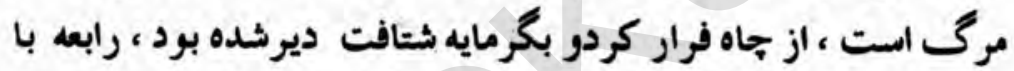

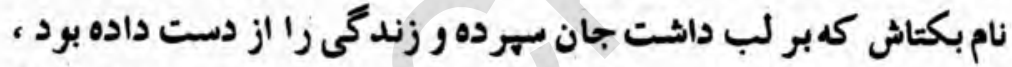
بكتاش جنان از خود بيخود گثت كه ديوانه وار هماندم سراغ حان حارث

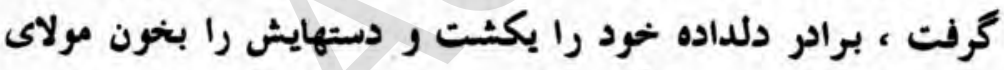

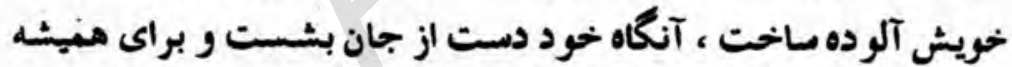
در كنار آرامخاه رابعه بخواب فرور رفت آلتحاه

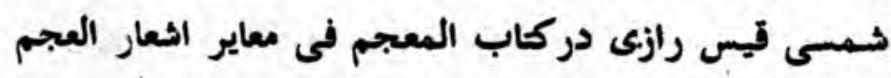

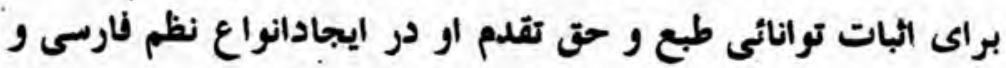

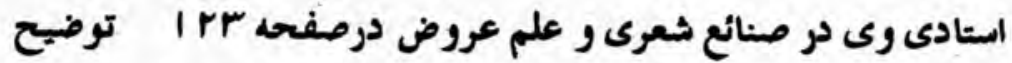

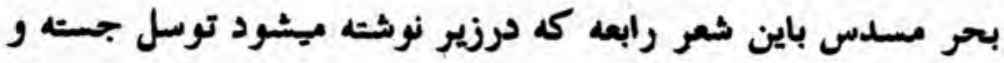

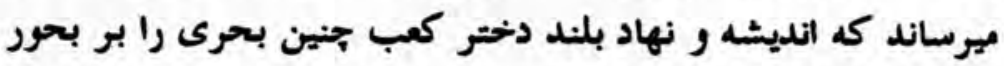

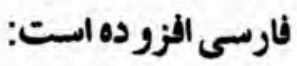

*** 
$\pi$

رابعهُبلفى

ترك از درم درآمـد خندانكى آن خوبروى جاببك مهمانكى

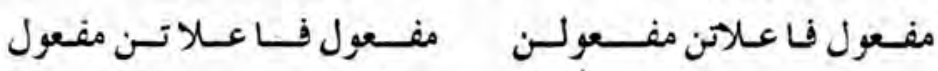

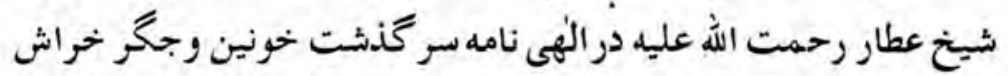
رابعه راجنين روايت ميكند:

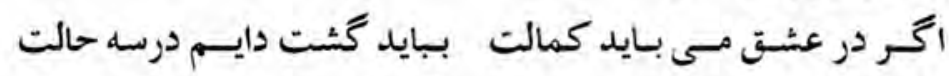

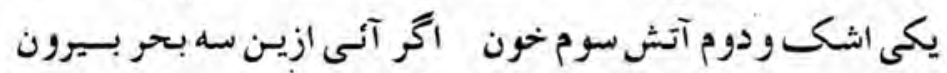

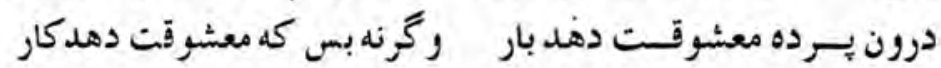

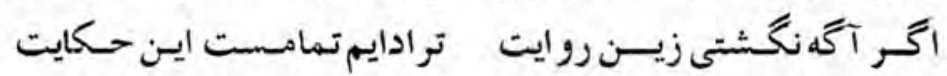

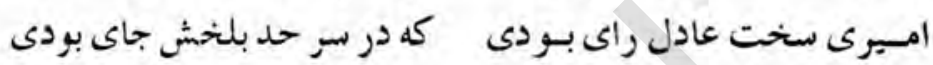

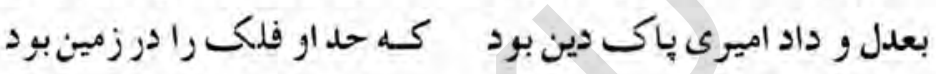

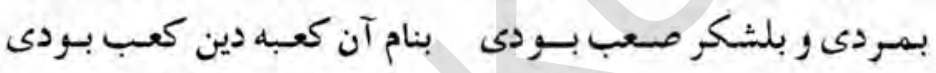

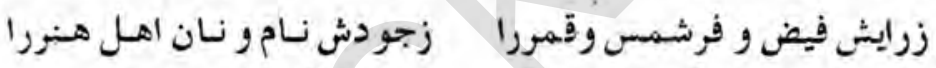

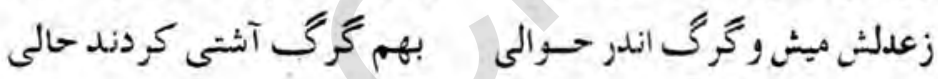
زسهمش آبدرياها براز جوش

شدى جون آتش اندر سنى خاموش زر حمت گر كهن بودى جهانى ندي زخهـاطر مسو كـردى در زمهانى زقهـرش آتسش ار افسـوده بودى جوانكشتى شدى اندر كبودى

زبجـاه او بلـندى مسانسده در جـار

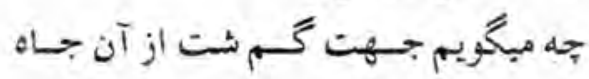
زحلـسش كــون بـر جساى ايستساده

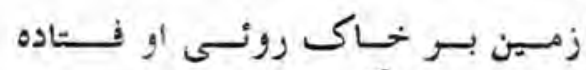

زخشسم رفته آتش بادلى تنحـ 


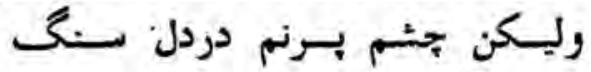

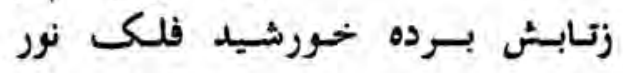

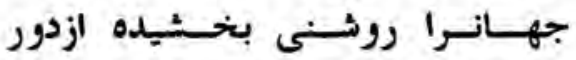

$$
\text { زجهودش بحسر و كـان تسشوير خورده }
$$

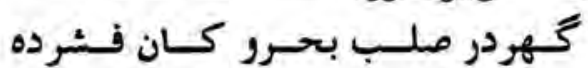

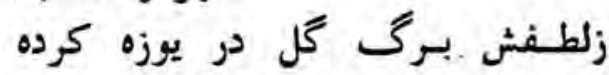

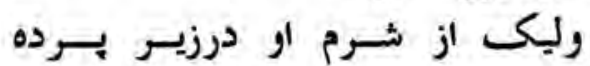

زخلـقش مشـك دردنسيا دمــــه

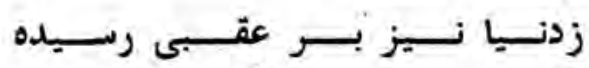

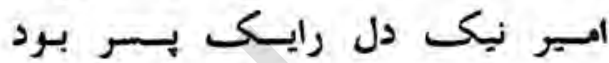

كــ در خسوبى بعالم در سمر بود

رخى جون آفتابى آن بسر داشت

كه كمتر بنده بيش نود قمر داشت

نهاده نسام حسارث شـاه اورا

كسمر بستئه جيو جـوزا مساه اورا

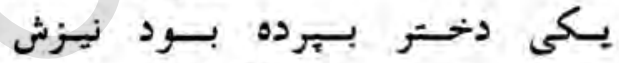

كـهـ جـون جان بود شيرين و عزيزش

$$
\text { بنام آن سبسمبر زيسن الـعرب بود جان بود }
$$

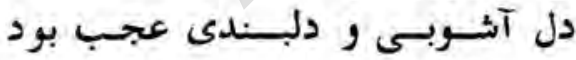

جمالش ملك خوبى درجهان داشت آن

بخوبى درجهان آن بود كان داشت

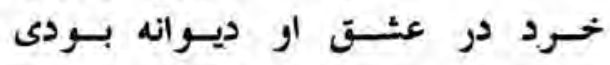

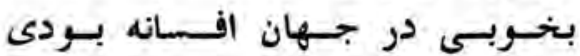

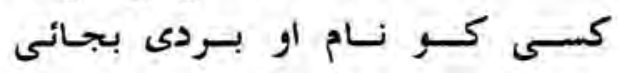

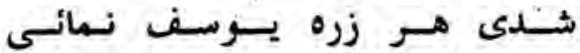

مس نسوجهون بـديسلى زآسمسانش 
زدى جون مشك زانسوهـر زمانش

$$
\text { اخـر يـشانسى اش رضسوان بديدى زدي }
$$

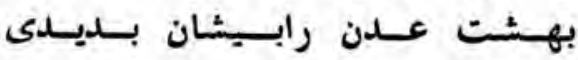

$$
\text { سـرزلفـش جـو درخاك او فتادى }
$$

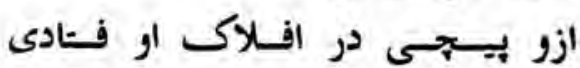

$$
\text { دو نـرگــ داثــت نـرگتسـدان زبادام }
$$

جــو دو جــادو دو زنكـى بجـهـ دردام

دو زنسگى بجه هر يكـ باكـمانسى دوري

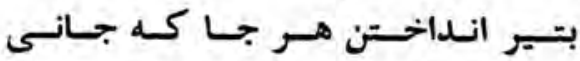

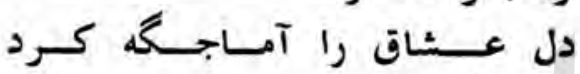

$$
\text { جـو تسير غمـزه او زه بسرد كـرد }
$$

شكـر از لـعل او طعمى دگر داشت

كه لعلش زهر دارو در شكر داشت داشت

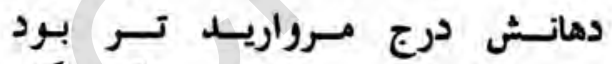

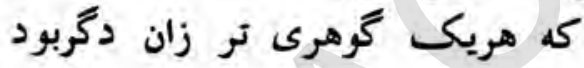

$$
\text { جوسىى دنسلدان او مرجان نسمودى }
$$

نستار اوثــدى هـر جــان كـه بودى

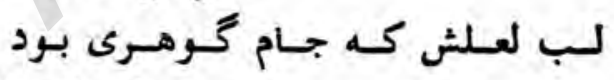

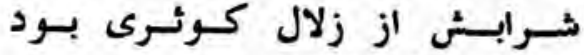

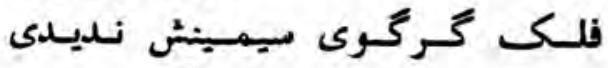

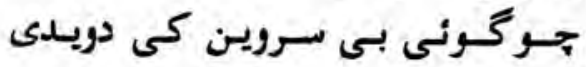

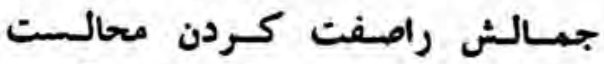

كه ازمـن آن صفت كــردن خيالست

بلـطف طبـع او مـر دم نسـبودى آدي

كه هو جيزى كه از مردم شنودى

مـمه در نــم آوردى بـــــم 
بيسـيوستـى جهـو مسرواريسـد درهـم

جنان در شعر گفتن خوش زبان بود

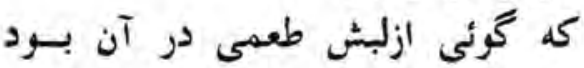

بدر بيوسته دل در كار او داشت

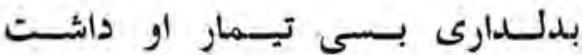

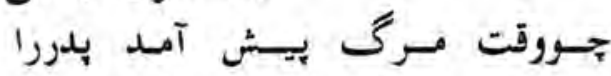

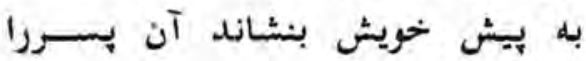

بسدوبسهرد دخستر را كـهـ زينـهار

زمسن بــــذ يـرش و و تيسمار ميسـدار

زهر وجهى كه بايد ساخت كارش

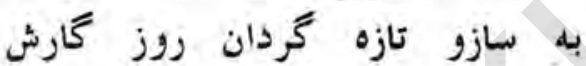

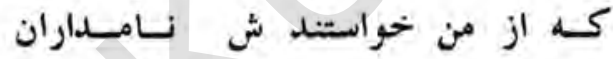

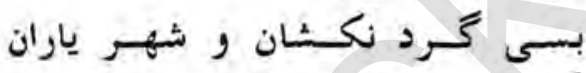

نسدادم مسن بكس گَـرتسر تسوانى

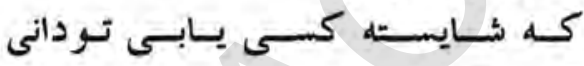

گــواه ايسن سخسن كـردم خهـدارا

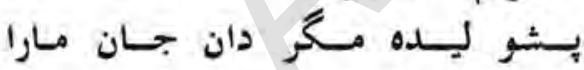

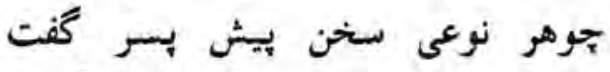

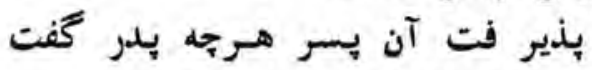

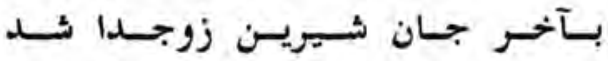

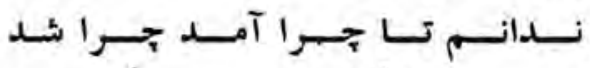

بسىى زيسر و زبـر آمسـد جــ افلاكى

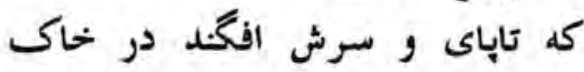

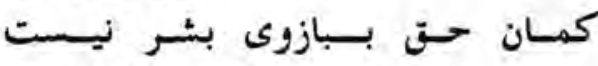

كزين آمد شدن كس نس راخبر نيست

كه ميداند كه بودن تابكى داشـت 
كيسى كـامد جــــا رفتن زبى داشت

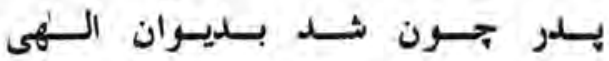

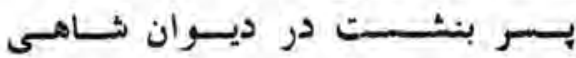

بعـل و داد كردن در جهان تافـت

جـهان از وى دم نوشسيروان يسافت

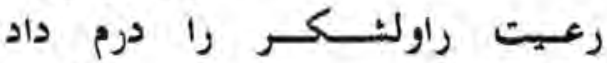

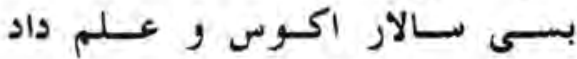

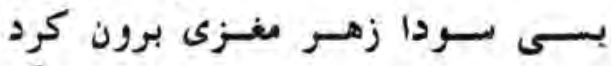

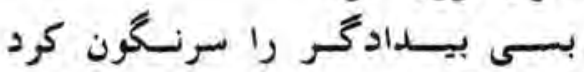

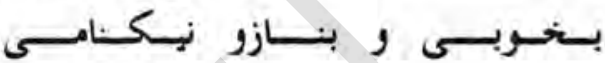

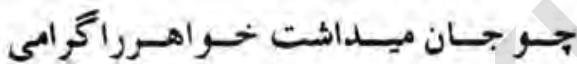

كنون يثشنز كه اين گردنده بـركسار

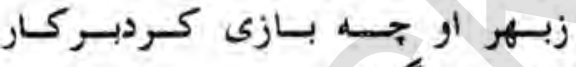

غـلامسى بسرد حسارث رايســانـ

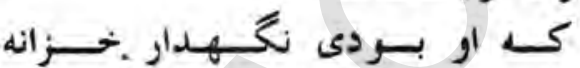

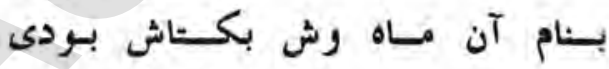

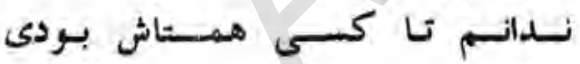

بخــربـى در جـهان اعجـوبه بود

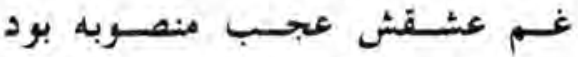

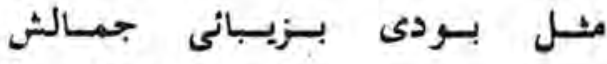

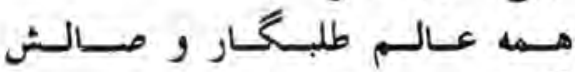

اخحـر عكــس رخسش گثــنى بلديدار

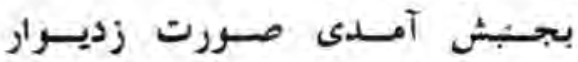

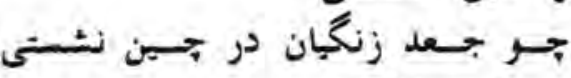

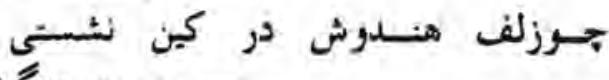

جوزلفش سر كثشانرا بنده ميـدائـت 
جنان نقدى زيس افكنده ميـداشــت

جـو دوا بسروش بـيوسته بــ آمسـد

كــمانى بــرد كساول فيزون آتـد

غنيسمى جوب جشم او أزان بــود

كـهـ بــا بــادام نقدش در ميان بــود

صف مرّمانش صف كردى شكسته

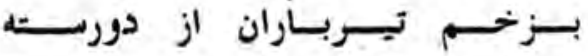

دهـان داتــت همسجسـون لـعل سفــه

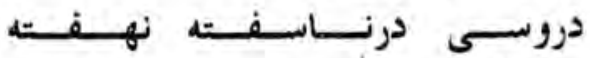

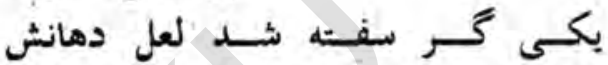

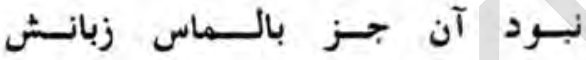

لبسش خسط داده عسمر جسـاردان ران

كــه آن لـب بــود آب خهضر جان ران ران

زدنســدانسـ تسوان كــردن روايــت

كـهـ دريكـ مـــيم دارد سى ودوريس

جسو يسوسف بسرو توئى در نكونسى

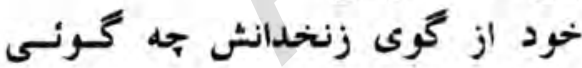

زگــويسش تسابسكى بهوش بـاشـــم

بـــ در گـــى آمدم خاموش باشم

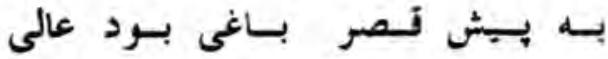

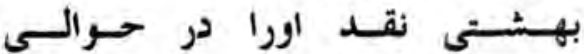

هـمه ثسب مى نخفت از عشق بلبل

طـريسق خسار كش ميخفت بـاتحل

گَلـل از غنسجه بصـد غنج و بصد ناز

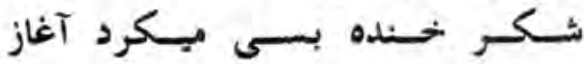

جسـان آمسـد كه طفلى مانده در خحسون 
گُلـ بــرخ از قـماط سبز بسيرون

صسبا همبجسون زليـخا در دوديسـده

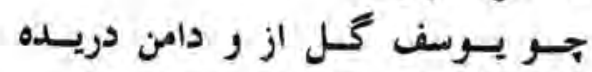

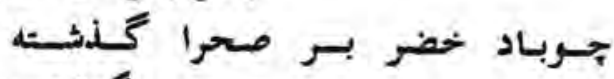

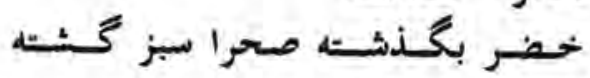

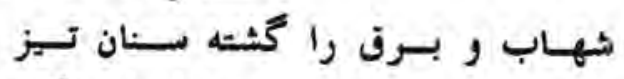

زبــاران ابسر كــرده حسـد عــان ريـز

كثـــده دسـت بر هم سبزه زاران

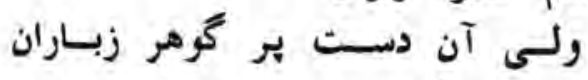

$$
\text { بنفـــ بـر بخسمت بيش كـرده }
$$

ولـكين بـاى بـوس حسويش كـرده

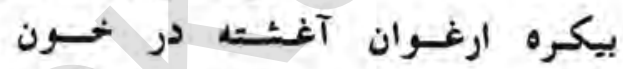

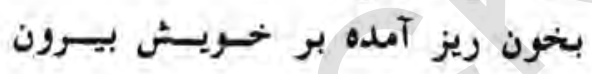

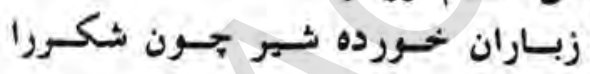

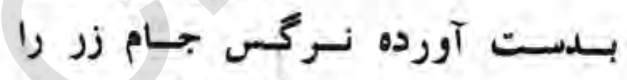

مسرلالـ جــ در بـاى او لــاده

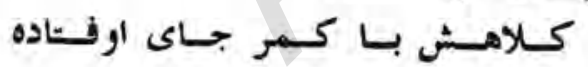

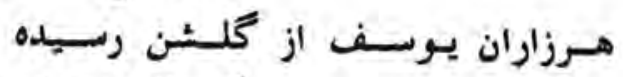

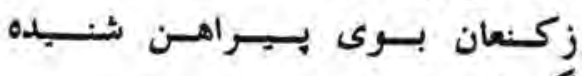

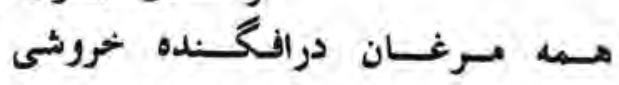

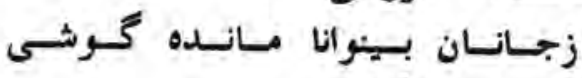

بـرقـت صبحسماهـى باد مشكـين

جسروسـوهان كرده روى آب برجين

مـكر السـراسـياب آب زره بافسـت

كــــ آب از بــاد نسوروزى زره يافت

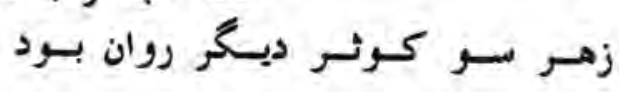


رابعه بلفي

ra

كـه آب خضر كمــر رشح آن بـود

زيسـش بــاغ طـاتــى تابكـيوان

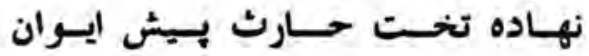

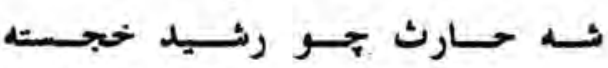

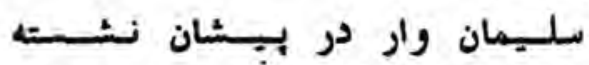

جـو جـوزا در كـمر دست غلامسان

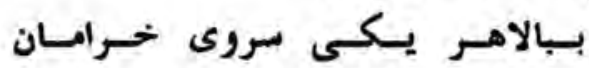

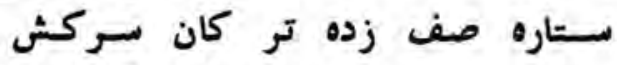

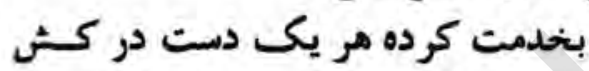

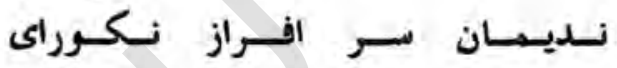

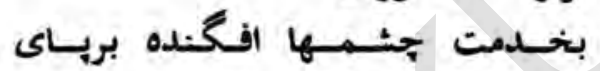

شـريفـان مــه عـالهم و ضعيسش

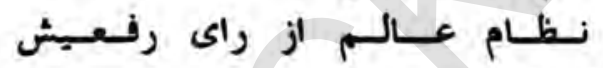

زبـــارى بـختـش فـــه درخهواب

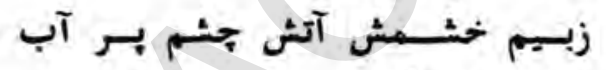

زحـل كين ، مشترى ر ش، ماه طلعت

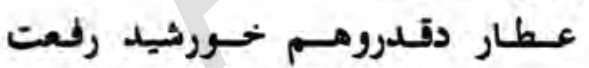

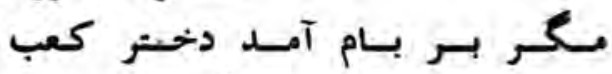

شكوه جشن در جشم آندش صعب

جولخسنى كرد هر سويى نسطاره

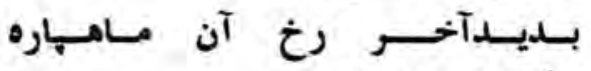

جـو روى و عارض بكتاش را ديد

جسو سـروى در فبـابـالاش را ديســ

جهـان حسن وقــف جهــره تور

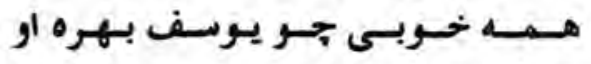

بساقى بيش شاه ايسـستاده بر جاى 
r.

\section{رابعئ بلفى}

سـر زلــــــ دراز افــــاده برإى

زمستى روى جون كلنار كـرده

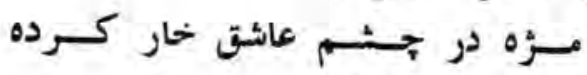

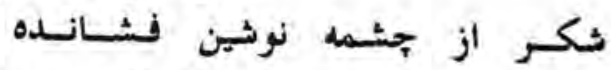

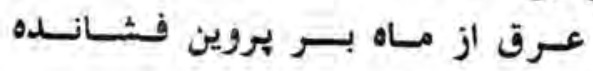

كهى سـر مست ميدادى ثــرابسى

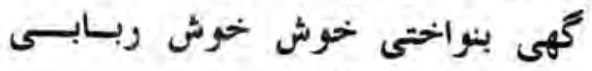

گهـى بردائستى جون بلبل آراز

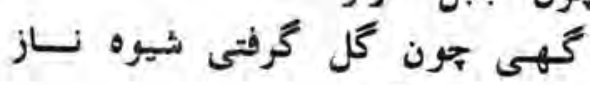

بدان خوبى جودختر روى او ديسل

دل خود وقف يكـ يكـ موى او او ديد

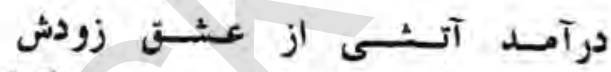

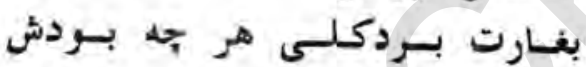

جسنان آن آتشسيس در جان اثر كرد

كـه آن آتش تنش ران كرد بيشتبر كـرد

دلـش عائق شد ر جان متهم گثـت

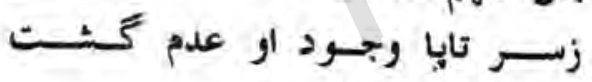

زد و نرگس جوابرى خون فشان كرد

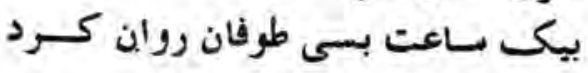

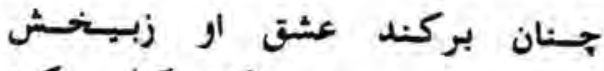

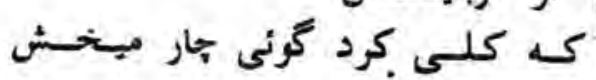

جـنان ازيكـ نظر در دام اوشـــ

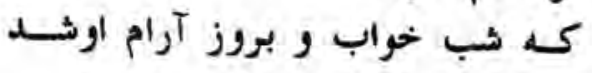

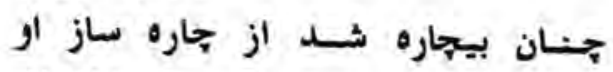

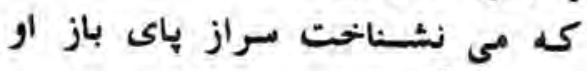

$$
\text { همه شب خون فشان ور نوحي گر بود }
$$


جو شعشش هر نفس سوزى دگكر بود

زبسس آتش كه درجان وى افتـاد

جسو آتسـ شــداز آن سراز بى افتـاد

على الجمله زدست رنج و تبـمار

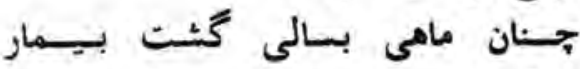

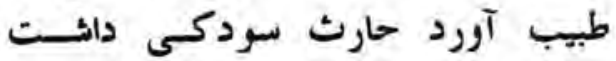

كه آن بت درد بيدر مان زبى داشت

جــان دردى كجا درمان بـذيسرد

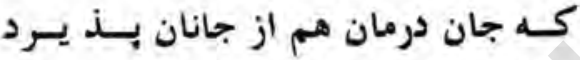

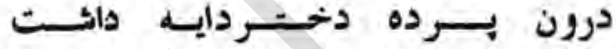

كـهـ درحيلت گرى سرمايه داشــت

بصد حيلت از آن مهروى درخواست

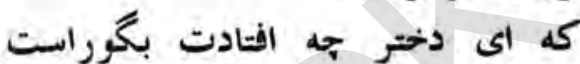

نسمى آنسلد مقـرالبسته آن مساه

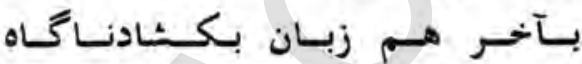

كـهـ مـن بـكــاش راديدم فـلان روز

بزلف و جهره جانسيوز و دول دل افـروز

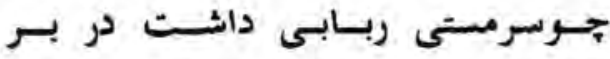

من از وى جون ربابى دانست بـربــر

بزخم زخمه در راهى كه اوخواست الهي

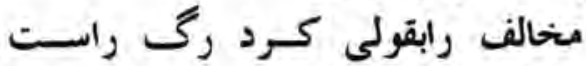

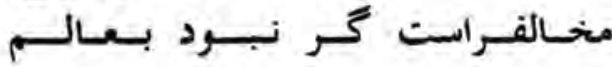

درآن بسرده بـسـازد زيسر بـابسم

دل مسن جـون مخسـالسف هـدجه سازم

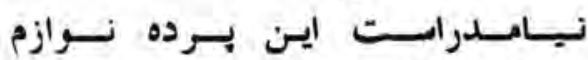

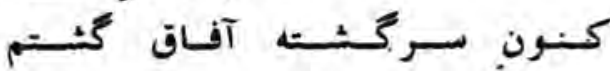




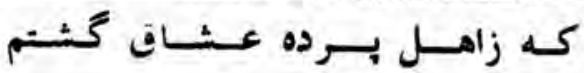

$$
\begin{aligned}
& \text { جـو بــــودم از آن نسركـش سـرودى زئس }
\end{aligned}
$$

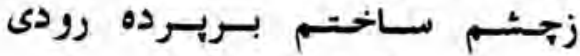

$$
\text { جـــان عـــــ مـرا بيخويش آورد }
$$

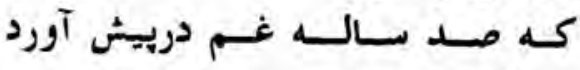

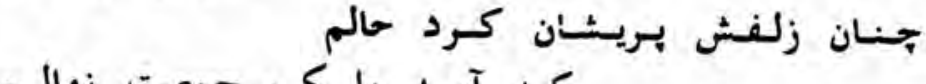

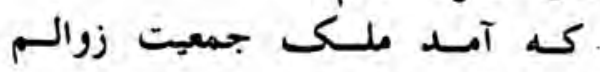

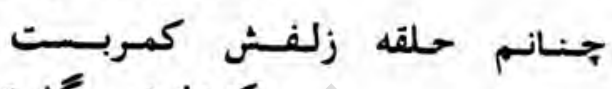

كه دل خون گثشت تاهمجرون جئر بست

$$
\text { جنسين بــمار و سرگردان از انسم }
$$

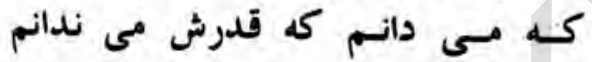

$$
\text { بخهـوبى كب جو بكتاش آن نسـارد }
$$

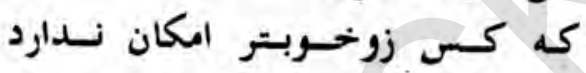

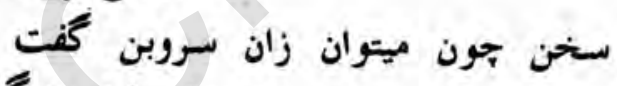

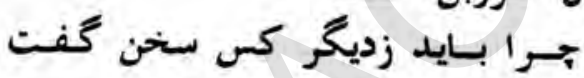

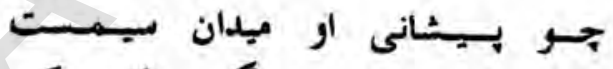

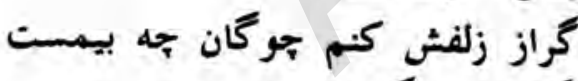

$$
\text { در آن ميدان بدان سر گُشته جو گانش }
$$

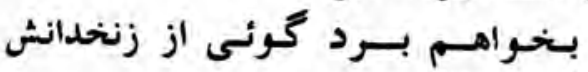

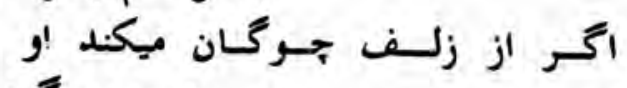

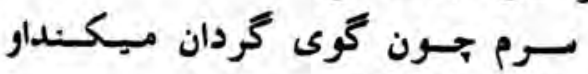

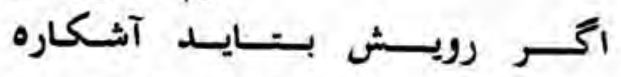

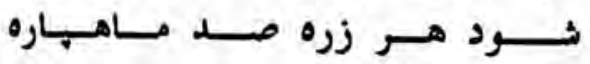

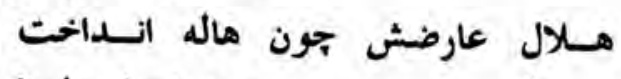

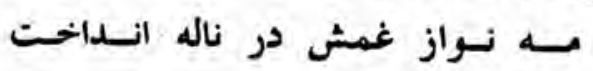

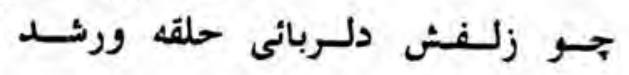


بهر يكـ حلقه صد جان در كمرثيسد

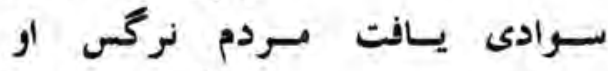

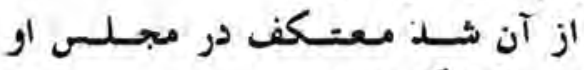

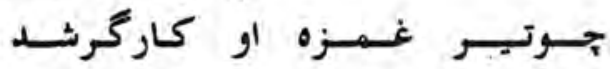

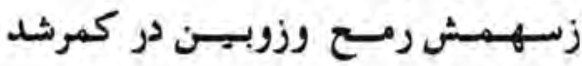

خطى دارد بدان سى لبـاره دنــدان

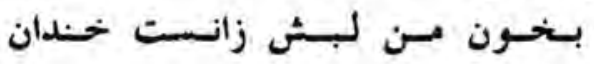

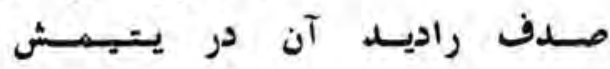

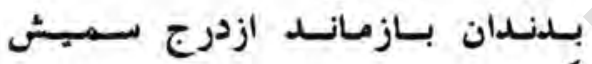

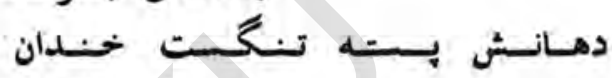

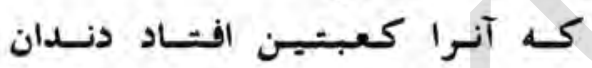

$$
\text { جـر حسح ار خســده آرد در تباشسير }
$$

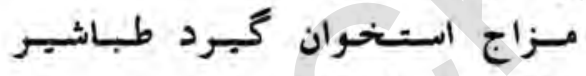

لبش را صد هزاران بنده بيش است آست التحان

كـه او از آب حيوان زنده بيش الست البـ

خسط نسبزش محقــق ارفتساد است

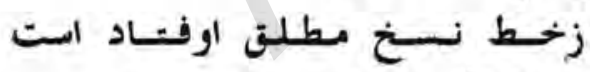

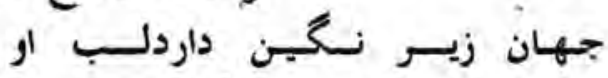

فلك در زيسر زين سـى كركب ارولى رون

زبسيبش بسربـهـى كـردم روانس

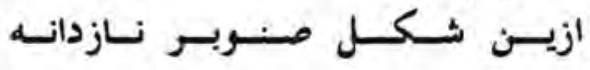

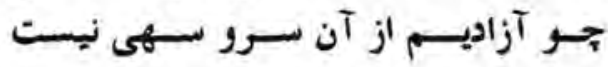

بهـى شـد رويم ور روى بهى نيست

كنون اى دايه بر خيز و روان شـو

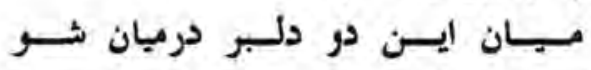

بـرو ايسن قـصه با او درمسيان نـــ 
اسـاس عـــق ايسن دو مهربان نسهـ

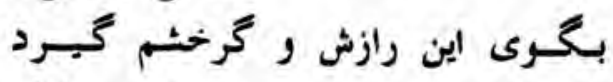

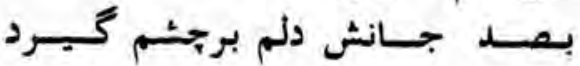

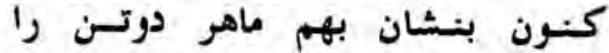

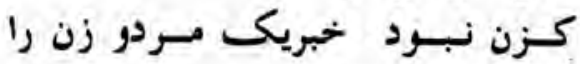

بـحـف اين و يكى نـامه اداكـرد

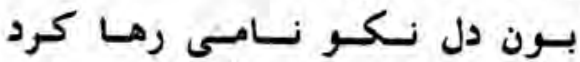

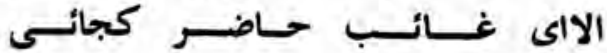

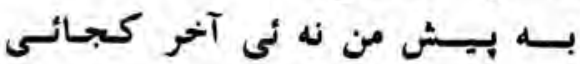

دو جــــم روبــــائى از تــــ دارد

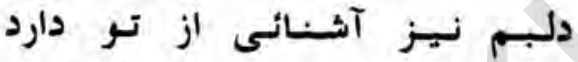

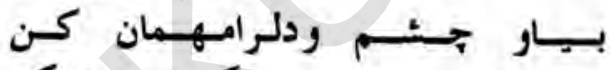

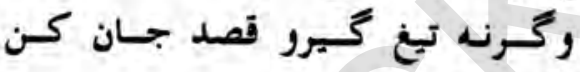

بــقد ازنعــــ ملكـ جـهانسى

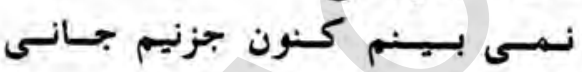

جـرا ايسن نــم جسان در تسو نبازم

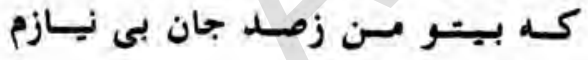

دلـم بـردى رگــر بـودى هـزارم

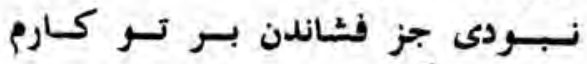

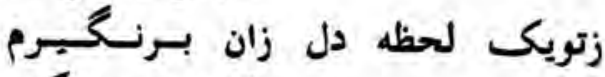

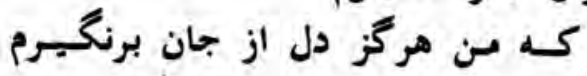

غـم عشتى تو درجان مى نهم مسن

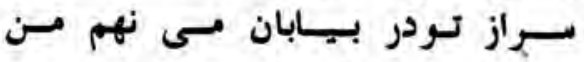

جــوبى 'رويت نه دل ماند و نه دينم

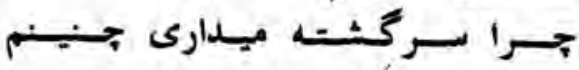

مـــم بـى روى تسو روئسى جو دينار 
زعـــــق روى تو روئى بــديسوار

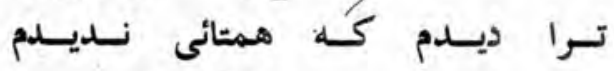

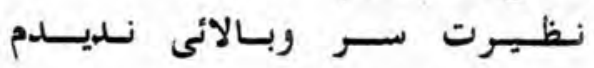

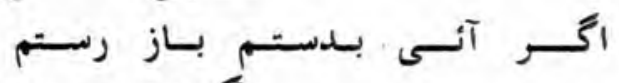

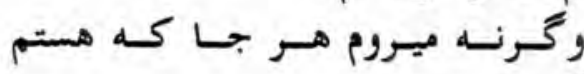

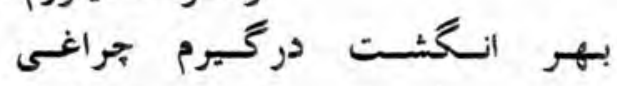

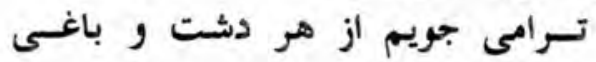

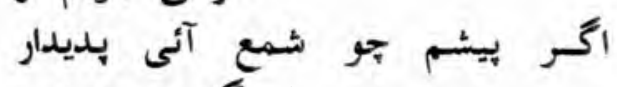

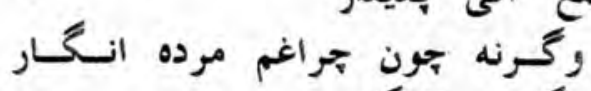

نسوشـت ايسن نامه وبنكاشت آنــاه

يـكى صـورت زبنـقش خـويش آن ماه

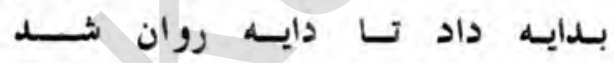

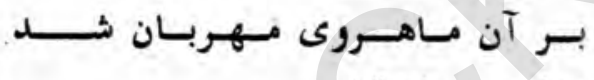

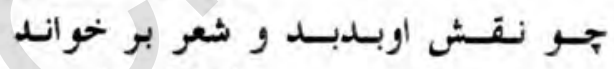

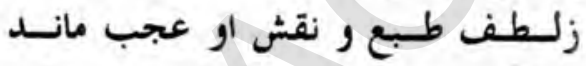

بيكى ساعت دل از دستش برون شد

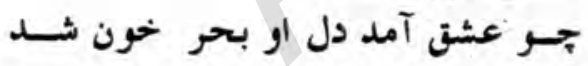

$$
\text { نهنح عشت در حالش زبون كـرد }
$$

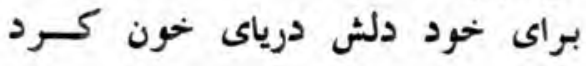

جهــان بى روى اوروى جهان ديسا

كـه گتفى نه زمين نه نه آسمان ديسـ

جو گتوئى بى سرو. بى باى مسفطر

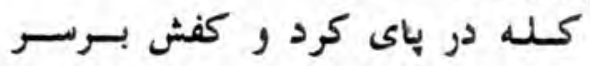

بسدايس گفت بو خيزاى نسكرگترى

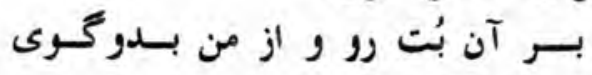

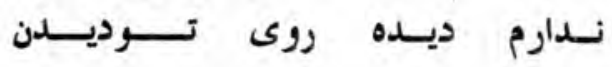




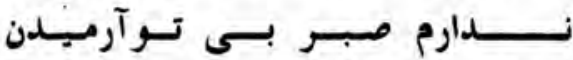

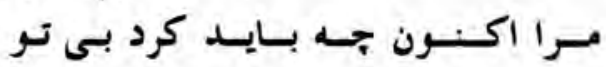

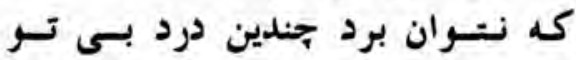

$$
\text { جـو زلف تـو دريده برده امن مسن بران برد }
$$

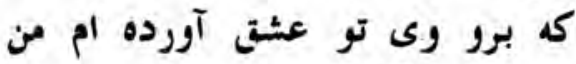

$$
\text { از آن زلـف توام زيـر وزبر كـرد برد }
$$

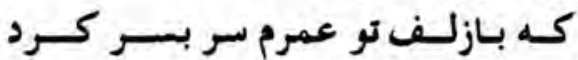

تسرا نساديسده در جـان جون نشستى

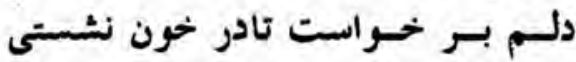

$$
\text { جـو تسو در جـان مسن بــهانى آخر }
$$

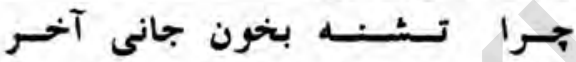

جسو صبحم دم مده اي ماه درمسيغ

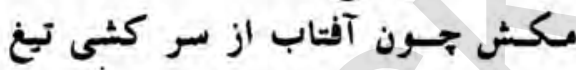

اتـر روثـن كـنى جشــم بلديدار

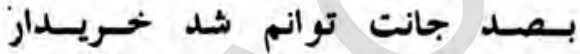

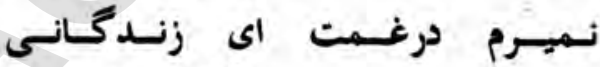

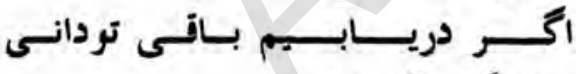

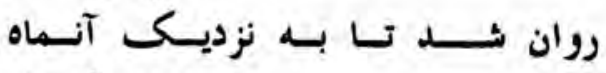

زعـشـق آن غـلامس كرد كرد آكـاه

كــهـ او از تسـو بسـى عاشق تر الفتاد

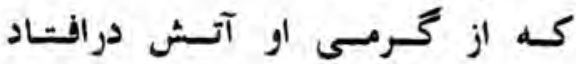

$$
\text { اخـر گـردد دلت از عشقش آكـاه }
$$

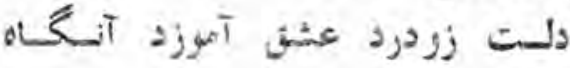

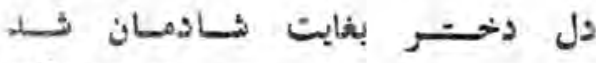

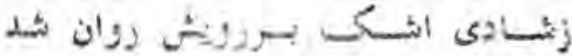

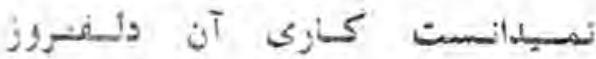


رابعة بلفى

$r$

بجسز بيت و غزل گفتن شب و روز

روان ميخـفت شعرو ميفربستاد

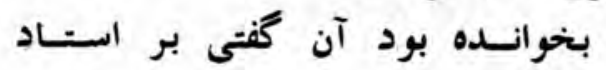

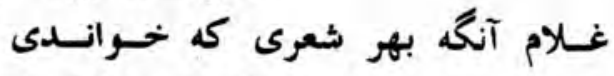

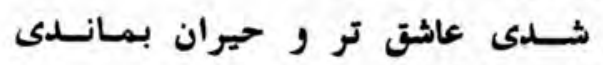

بريسن جون مدتى بحذشت يـك روز

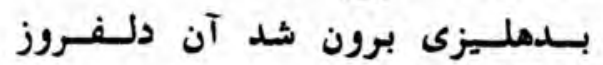

بـدبدش ناكهى بكتاش وبشـــاخت

كه عمرى عشق بانقش رخش برت باخت

كرفستش دامسن و دخستر برآشفــت

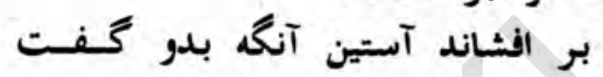

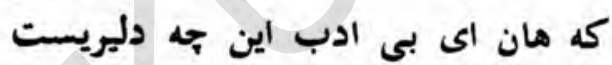

تسو روبـامى ترا جه جاى شيريست

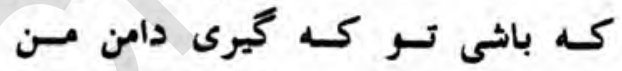

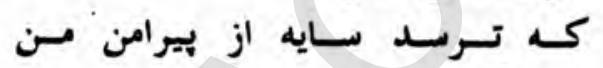

غـلامسش تفت اى من خاك كويت

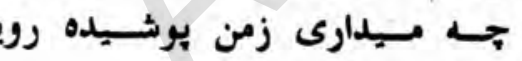

جـرا شعرم فـرستادى شب ر روز

دلـم بــردى بدان نقش دوز دلــفروز

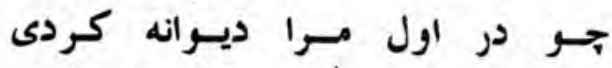

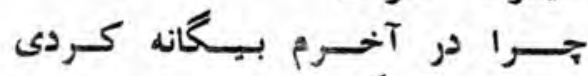

جـوابش داد آن سيـمنبر آنـاء

كـه يكنره نه لئى زين راز آنساه

مسرا درسينه كسارى او فستاد· اسست

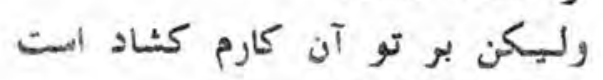

جنين كارى جه جاى صد غلام است 
بشودادم بــرون اينت تمام السـت

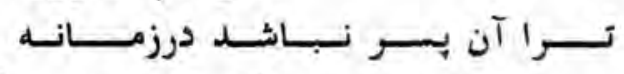

كسـهـ تسو اين كاررا باشى بهـانسه

اسساس كسئور بــهـادى درين راز بـاز

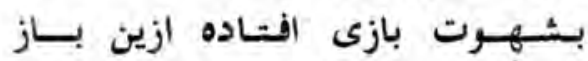

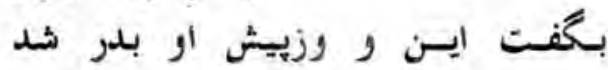

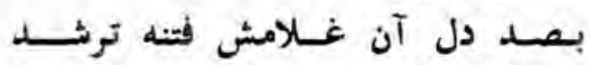

***

$$
\text { زلسفط بسوسعيد مهـن ديسدم }
$$

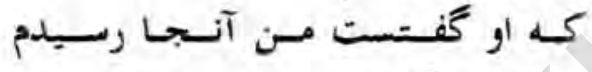

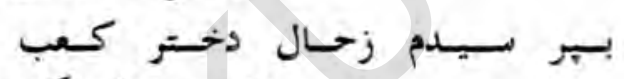

كه عـارف تُشته بوداوعارفى صعب

جنين گفت او كه معلومم جــانَ شد

كه آنشعـرى كه برلفظث روان شد شد

$$
\text { زسـوز عثلق معسشوق مجسازى }
$$

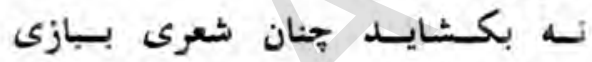

نسداشت آن شعر با مخلوق كـارى بـاي

كسه او رابسود بـا حست روزئسارى

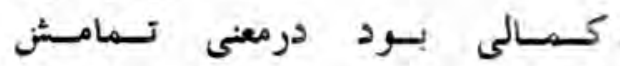

بهانه بسود در رإه آن غسلامسي

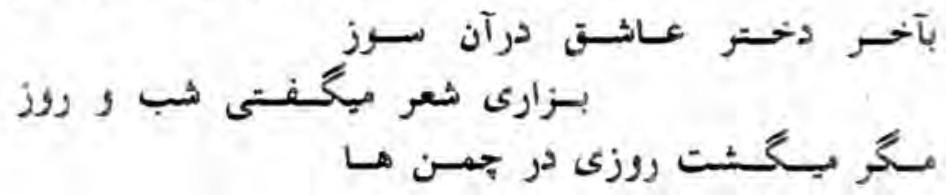

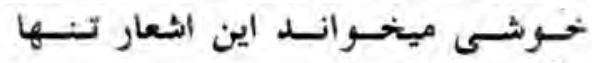

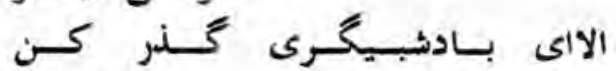

زمس آن تسرك يغسما را خبر كن 


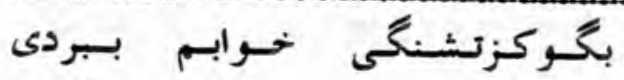

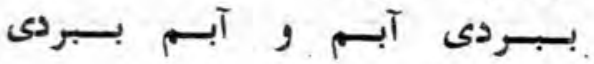

مسكر حارث از آن سوى جـمن بــود

بـــوش حارث آمد اين سخن زود

بجـوشيد و برززد بانگ نـاگتـاه

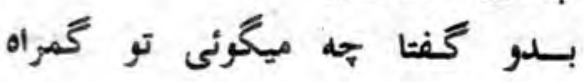

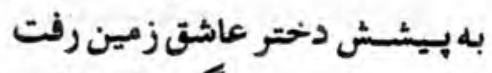

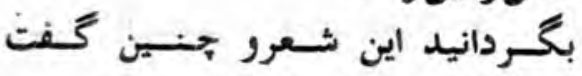

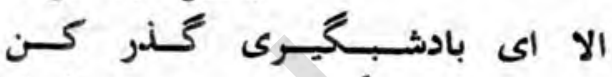

زمــن آن لعل سـقارا خــبر كـن

يسكى ســـاش بودى سرخ رونسى

كــه هبر وقت آبش آوردى سـبونئس

بسجساى تسرك يغما خاصه آن مبـاه

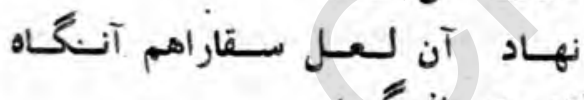

بسرادر را جنان در تهمت افحــد

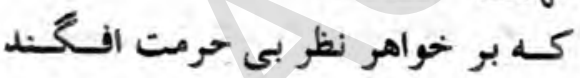

$$
\text { كــرفت اندر دل همشـيره كـيـهنه }
$$

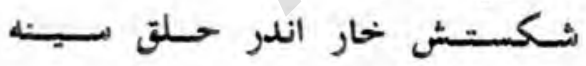

\section{*** * *}

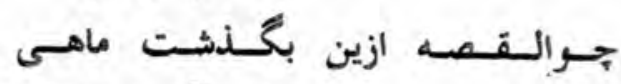

در آمسد حسرب حارث راسبـاهى

$$
\text { سـباهـى و شـــارش از عـدد بيسش }
$$

جــو دوران فلـك از حصر و وحدبيش

$$
\text { نسباهى موج زن از تيغ ر جــوشـن }
$$

جهان از تيغ و جوشن كُونته روشن

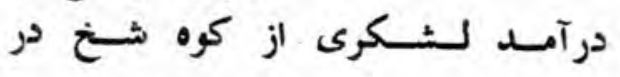


كه شد كا و زمين جون خريه يخ در

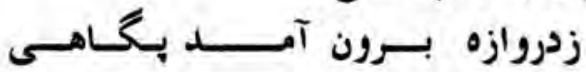

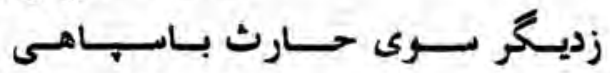

$$
\text { جسو بخـت او جسوان يكسـر سياهش }
$$

جسورايسش مرتفع جــترو كـلاهــ

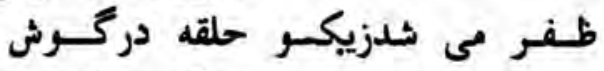

زيـكسر لتح و نصرت دوث بــردوش

$$
\text { سـبه اللقصـه افسـادنـلد در هـم }
$$

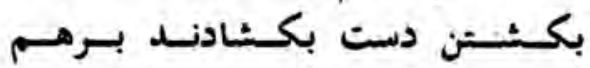

غـــبارى از هــه صحسرا برآمسـد

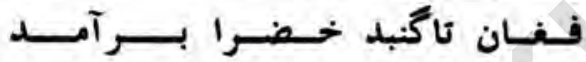

خروش كوس كرش جرخ كر كرد

زمسن جـون آسمان زبروزبر كـرد

زمسين از خـون خصمان لاله زارى

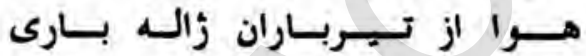

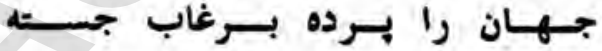

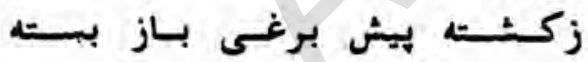

$$
\text { ابـل جنـال بـرجسان تيسز كـرده }
$$

قـفـا بـركينه دنسلدان تيز كـرده

هـويسـدا از قيامت صد عـلامست

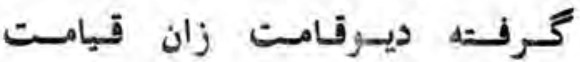

درآمـد بـيش آن صف حارث آنـــاه

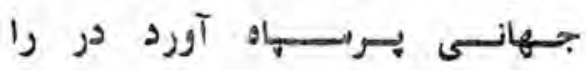

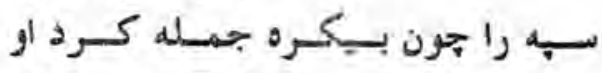

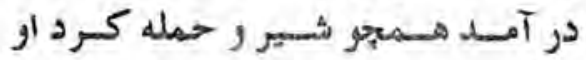

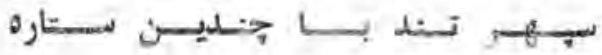


شـــده از شـــاخ رمستش باره بـــاره

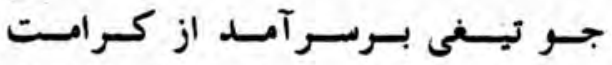

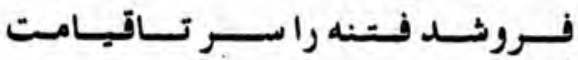

جو تيغش خصم را جون گًل بخون شست

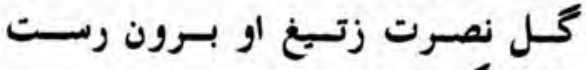

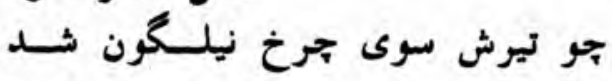

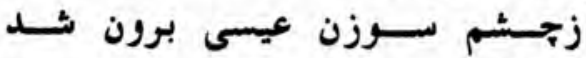

$$
\text { وزان ســوى ديخر بكستاش مهـروى زئم }
$$

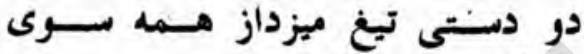

بـآخر جشم زخمى كارگتر گثـت

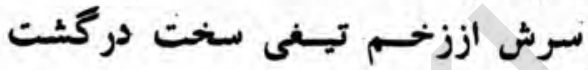

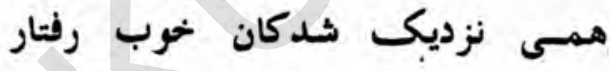

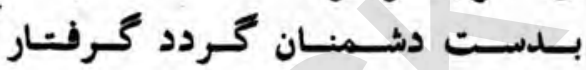

درآن حسف بسرد دخستر روى بسـهـ

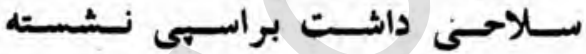

به بــش صف در آمد همجر كـوهـى

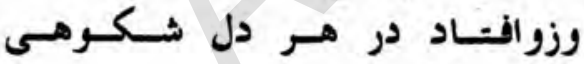

نميدانست كس كان سيمبر كيست وزتي

زبان بكشادوگفت ايسـن كاهلى جيستـ؟

من آن شاهم كه فرزينم سبهر اسـت بكت

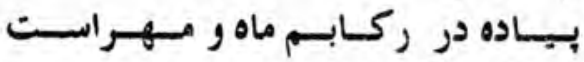

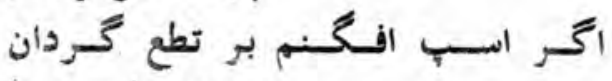

دوزخ طرحش نهم جرون شير مودان

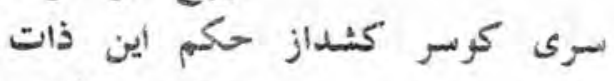

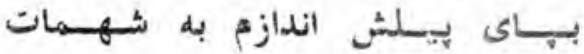

$$
\text { اكـر شدئير بسران بر كـشم مسن }
$$




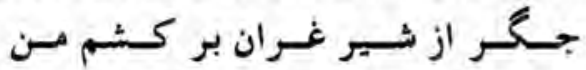

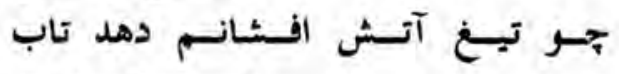

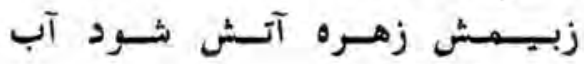

$$
\text { جسومسار رمح را دركف به بيسجم }
$$

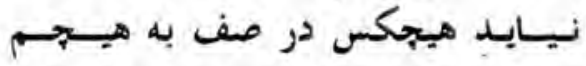

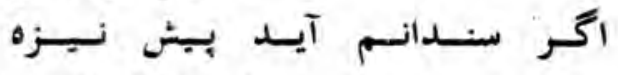

شــود از زخسم زخسمبم ريسزه ريسزه

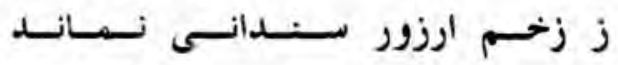

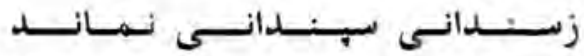

$$
\text { جـر مسرغ تسير مسن از ره در آيسد }
$$

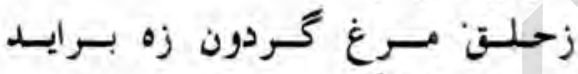

$$
\text { جـر بكـشايسـم كمــد از روى فتراكى }
$$

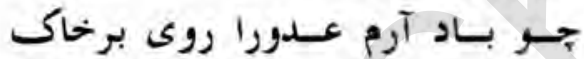

$$
\text { بتسازم رخسش و بكسـايم در فسصل }
$$

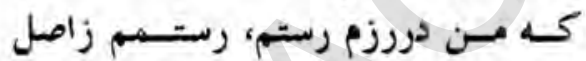

بكفت اين و جو مردان برنشست او

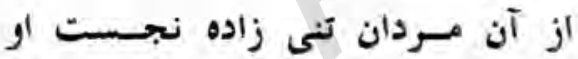

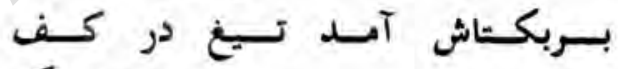

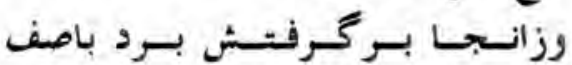

$$
\text { نهادش بـس نهان ثــــ درميـانه }
$$

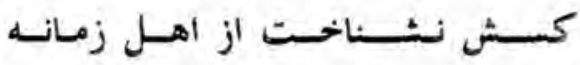

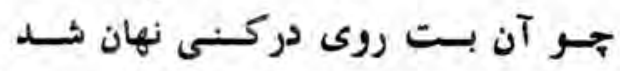

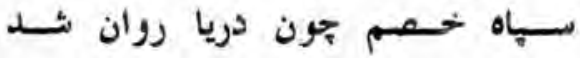

$$
\text { هـمى نـزديكى آمسد نا بـكـبار }
$$

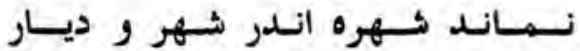

$$
\text { جـر حسارث رامـدد گثت آثـكـارا }
$$


بـسى خـلـق از بــرثـاه بسخسارا

$$
\text { هـزيمـت ثــد ســـاه دشسمسن شــاه }
$$

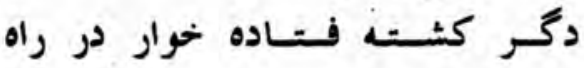

$$
\text { جسوشــه بـا شهرآمد شاد و بـــــروز }
$$

طلـب كرد آن سوار جست دور آن روز

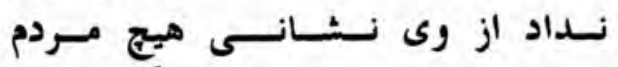

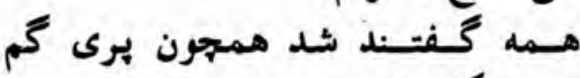

علـى الجـمله جــر آمد زنــى شـب

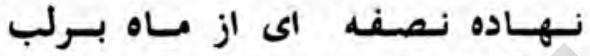

همه شب قرص مه جون قرص صابون

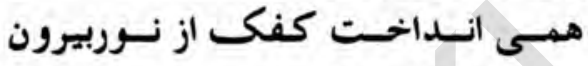

بــدان صسابسون زخون ديده تـــ روز

زجان مى شست دست دون آن عالن عالم افروز
دلارام
درآمـد زان زان
جسوزاغ

دل دخسترجسو مرغسى بـود در دام دوام

دل از زخم غلامش آن جنان سوخت

كه دريك جشم زخمش نيز جان سرخت

$$
\text { نبودش جشم زخسـى خواب ر آرام }
$$

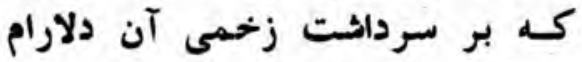

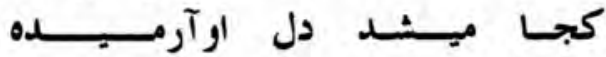

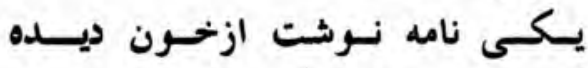

جنسين آورد در نظم آن سمن بـــى ناه

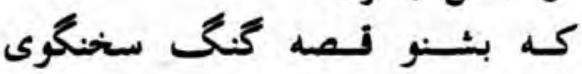

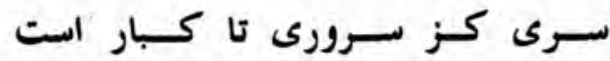

سريكان در آن سر درجه كار ست ست

سـرخصـمت كـه بـادايى سروكسار 
مبسادا سـر كـنـد جسز بـر سـردار

$$
\text { بسريواكز و جودت ســرورى نيست }
$$

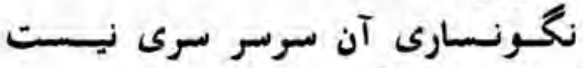

ســرى كان سرنه خحاك اين درآيـد

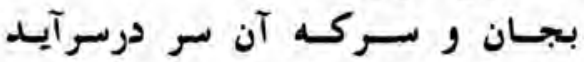

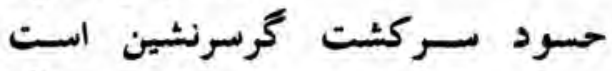

جو مارش سربكف كان سر جين است

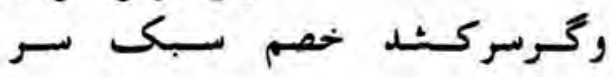

سرش بـر، نه مرش در كش سبكــر

$$
\text { بسرى كان سر نلدارد باتو سرراست بـر، }
$$

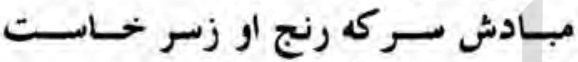

$$
\text { جـو سر بهد عدوكز سر درآيد }
$$

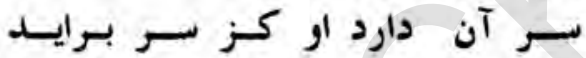

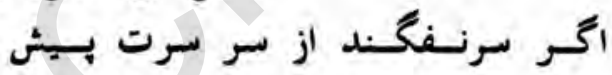

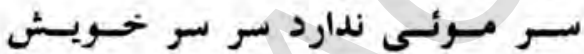

سر سبزت كه تاج ازوى سرى يافت نسرئ

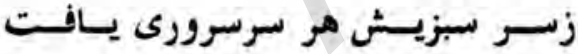

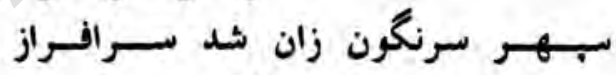

كـهـ هـردم سـر نهل بيست زمسرباز

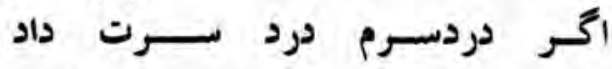

سـرخصــمان بـريسـده بـردرت بـاد

$$
\text { نسهـادم بـــ آن بسر بـرزمين بسر }
$$

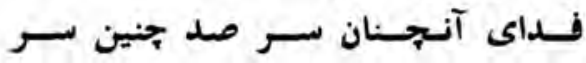

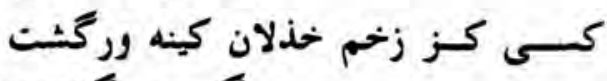

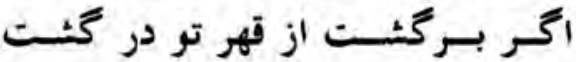

$$
\text { كسـى كـزشاخسـار عيش بـر خسـورد }
$$




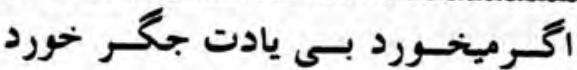

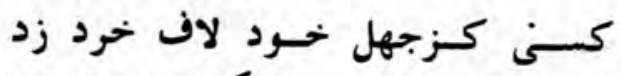

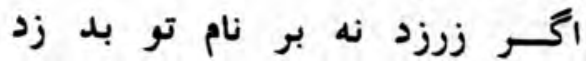

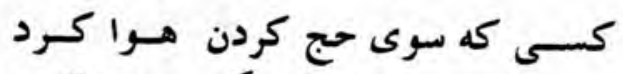

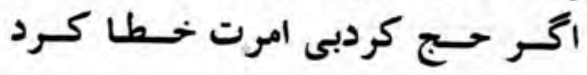

جسه افسـادت كه افتـادى بخسون در

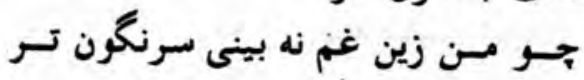

همسه شـب همسجـو شمعم سوزدر بسر

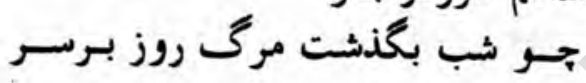

جــو شمـع از عـشق هودم بازخسـندم

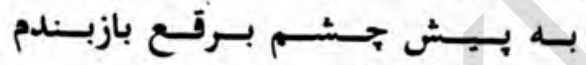

جـو شـمع از عشق جانسى زده دارد

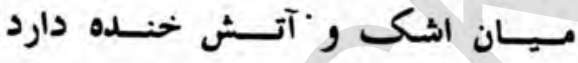

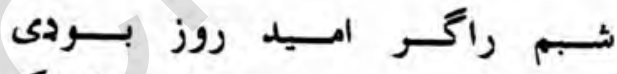

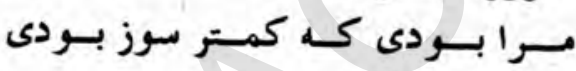

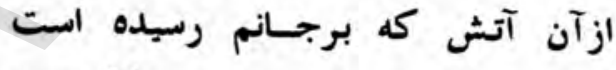

بسـى بايان مجو كانم رسيده السـت

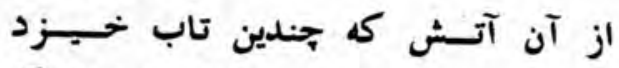

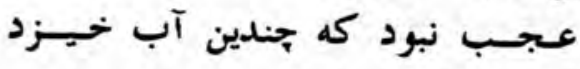

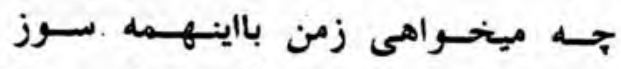

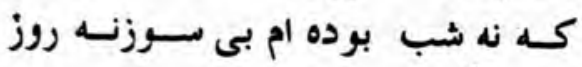

مـيـان خـاكى درخونم مخـــ دان برده

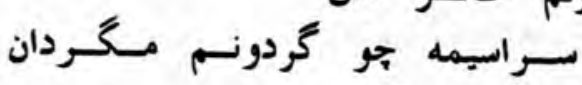

جــو سـر گــردانسـم ميدانى آنسر

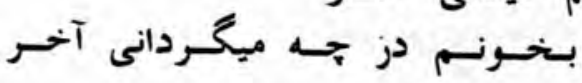

جسه ميسدانسى كه سرمست تو ام مسن 
زيـاى افـــاده ازدست توام مسن

مسن خسونخسواره خونى جون نكردم

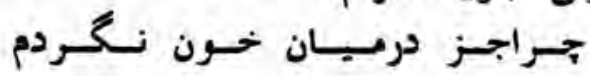

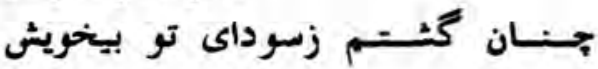

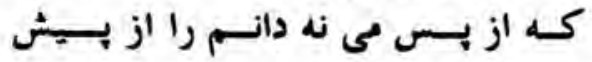

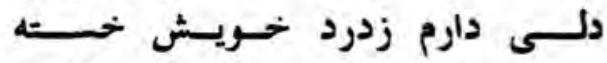

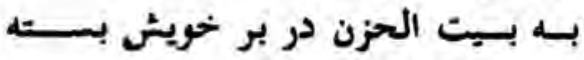

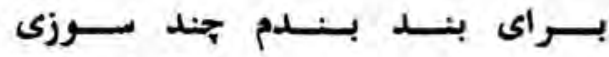

بـر آتس جون سبندم جند بـــــ

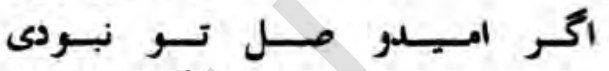

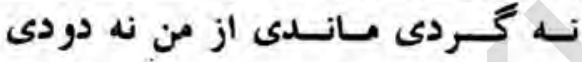

تسر ·تسر دامسنى آمد بجان زيسـت

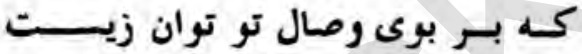

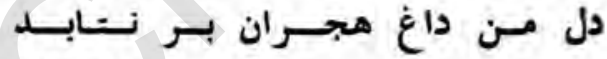

كـهـ دل خــود وصسل جـانسان بـرنتايد

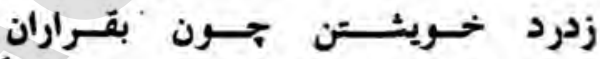

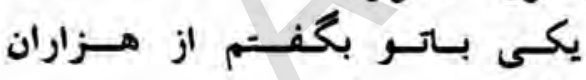

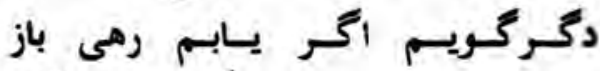

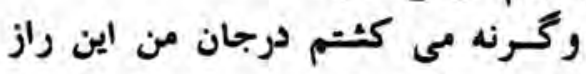

$$
\text { روان هــــ دايــه وايـن نسامـه هم بــرد }
$$

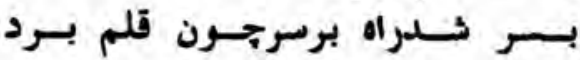

سـر بكستاش با جسـدان جراحست

زبسر نـامه مـرهـم يـافت وراحست

زجشــش كثت نيل خحون رواتــ

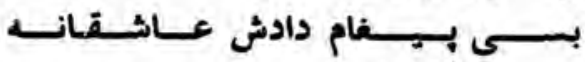

$$
\text { كـــه جـانـا تـاكيم تسنها خـذارى }
$$


ســر بـــــمار هـرسـيدن نسـدارى

جسو دارى خسون مردم جون لبسيبنان

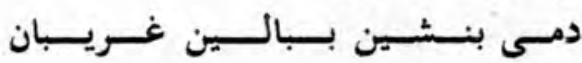

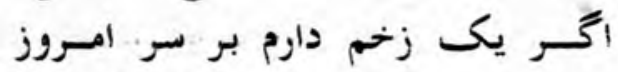

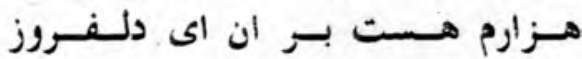

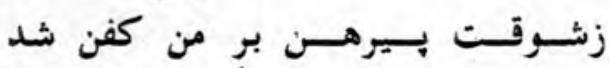

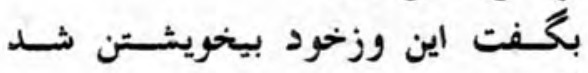

جــو روزى جنســدرا بـكــاش دمسـساز

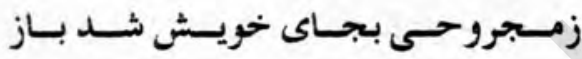

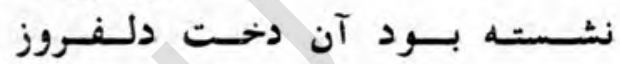

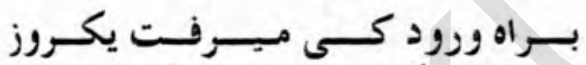

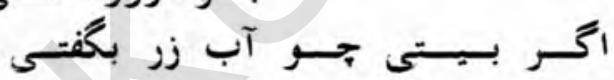

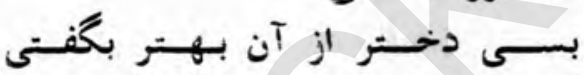

بسى الشعاز عفت آن روز استساد

كـهـ آن دخهـر مجابـاتش فرستـاد

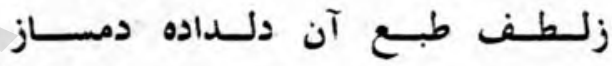

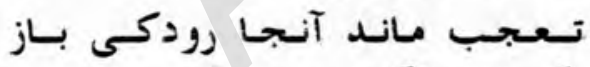

زعسشت آن نسنسبـر كـثت آكـاه

نسمبـاد آنسكاه از آنجس بـاه

جسوشــد بر رودكــى راز آشـكارا

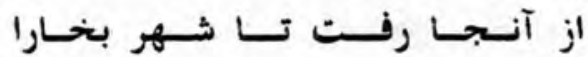

$$
\text { بــــــمت شـــد روان تابيش آن شـــاه }
$$

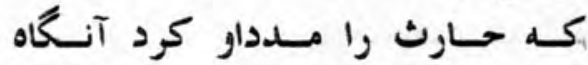

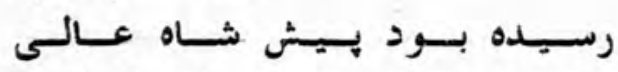

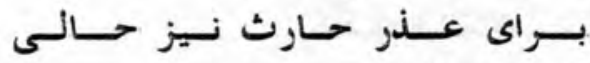

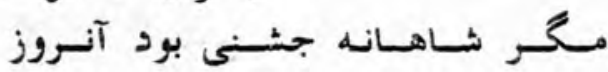


جـهـ ميـــــــــم بهشــى بددلفــروز

مــــراز رود كى شه شعر درخواست

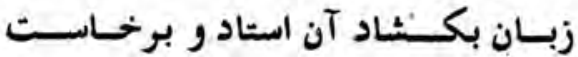

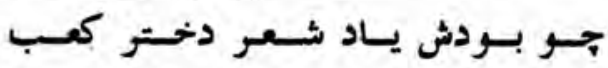

همه برخواند و مجلس كرّم كرم شد صعب

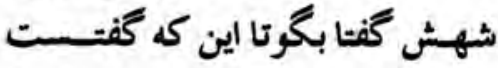

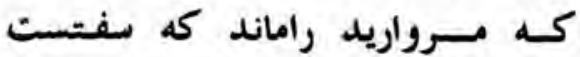

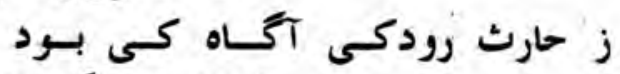

كه اوخود گرم شعر و مست مى بـ بود

$$
\text { زبسر مستى زبــان بكـــاد آنسكـاه }
$$

كـه ثـعر دخستر كعبست الى شــاه

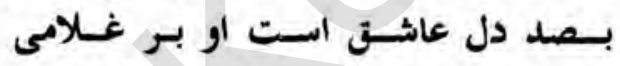

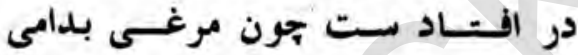

زمسانسى خسوردن و خففتن نسدارد

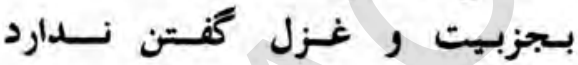

$$
\text { اخـرحسـد ثـعر گـويسد بـر معـانسى }
$$

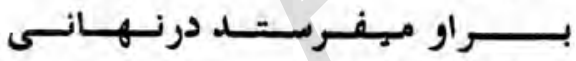

$$
\text { اخـــــ آن عشــق جـون آتش نبـودى }
$$

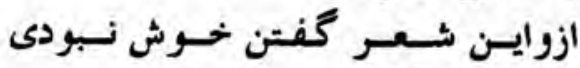

جو حارث اين بخن بشنود و بشكست أبست

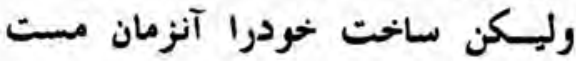

$$
\text { جــو القـصه بشـهر خويش شد بــاز }
$$

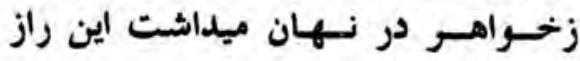

$$
\text { ولى بيسوبسته ميسجوشـيد جـانسش }
$$

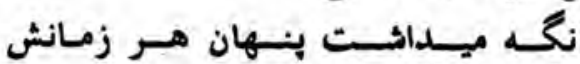

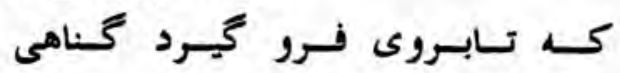




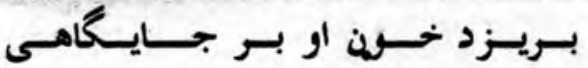

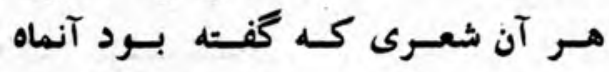

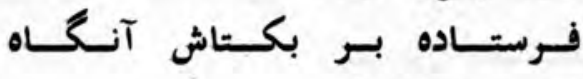

$$
\text { نسهـاده بـود در درجسى بـاعـزاز }
$$

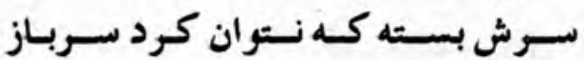

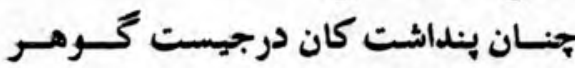

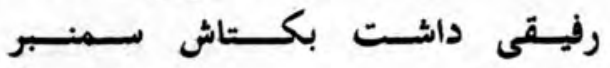

سـرش بكشادوآن خطها فرو خوانسد

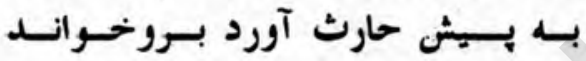

دل حارث بر آتش كثت از آن راز

هـلاك خسوامـر خــودكــرد آغــاز

در اول آن غـــلام خـــاص راثـــــاه

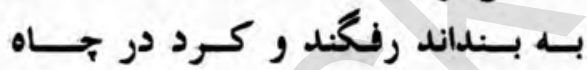

درآحسر كفــت تايكـ خانه حسمـام

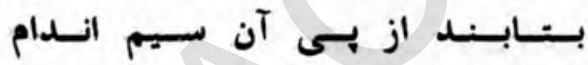

شــــه انــه گفــت تاز هر دودستـــ

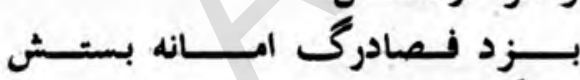

در آن گ قـرمسابه گرد آنگاه شاهـش

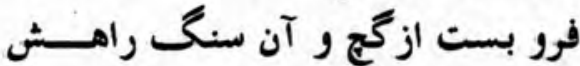

$$
\text { بسىى فــريادكـرد آن ســرو بـز آزاد }
$$

نبـودش هيسج مقصـودى زفـريساد

كه دانسـد تاكه دل جون مى شد از وى

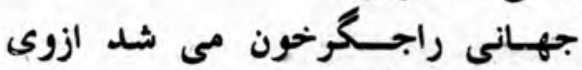

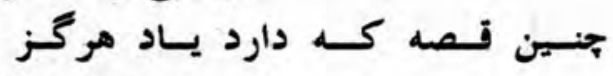

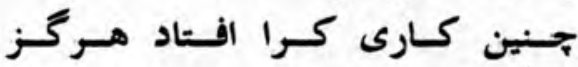

بــدين زارى بــدين دردو بلدين سوز 
كـهـه هرگز در جهان بودست يكــروز

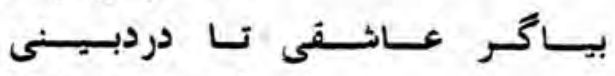

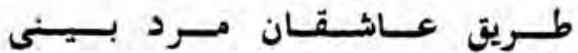

$$
\text { درآسـد جــد آتسش گتردآن مـــاه }
$$

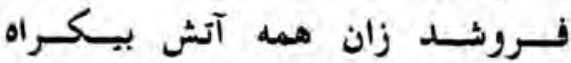

$$
\text { يكى آتسـ از آن حسمام ناخسوش }
$$

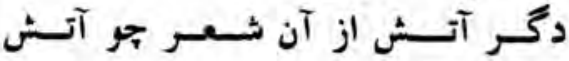

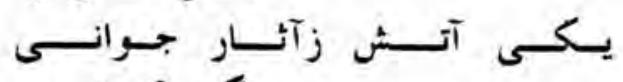

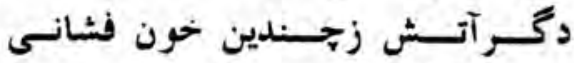

يكى آتسـ زسوز عشت و غسرت

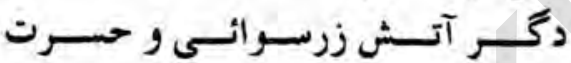

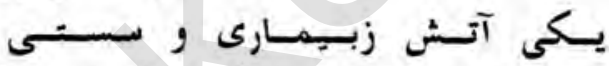

يكسى آتسش زدلــــــى و مستـى

كـهـ بنسشاند جنسين آتـش بصد آبـ

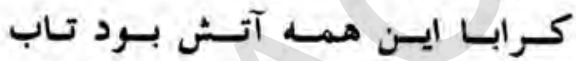

$$
\text { سـرانسخــت در خسـون ميسزد آنماه }
$$

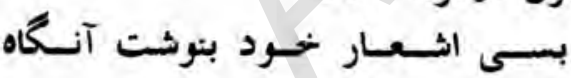

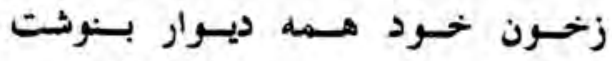

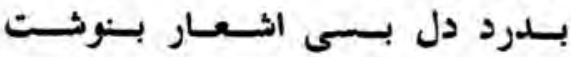

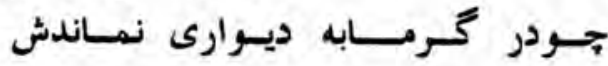

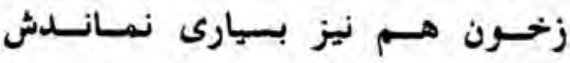

هـمه ديسوار جسون بركرد زاشسعـار

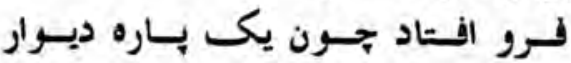

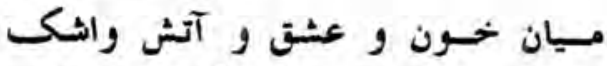

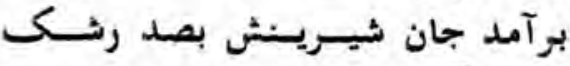

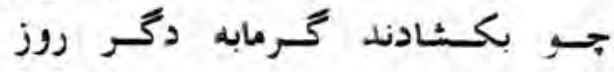


جه گويم من كه جون بود آن دلفووز

$$
\text { جـوشـاخسى زعفوان از بـاى تا فــرف }
$$

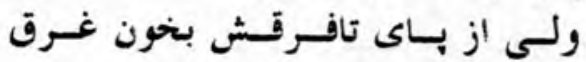

دل بـر خهـونسش زيسرخساك كردند

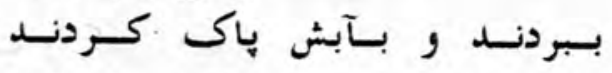

نـعـه كـردند بـر ديـوارآن روز

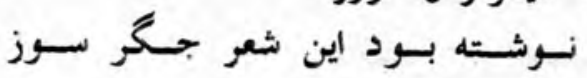

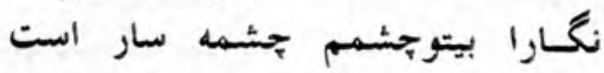

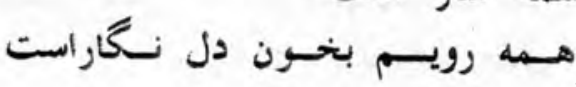

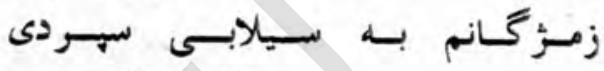

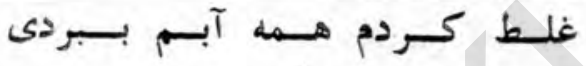

$$
\text { ربودى جان و دروى خسوش نشستى على على }
$$

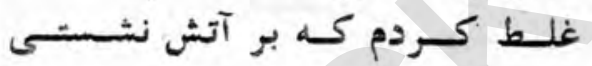

$$
\text { جـو دردل آمسدى بيسرون نسيائسى }
$$

غلط كـردم كه تو در خحون نيسائسى نـ

$$
\text { جو از دو جشمم من دو جوى دأدى }
$$

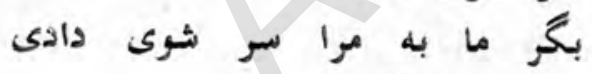

$$
\text { منسم جهون مساهـى بسرتسابس آخسر }
$$

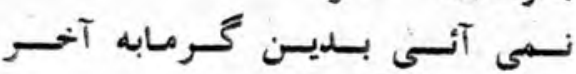

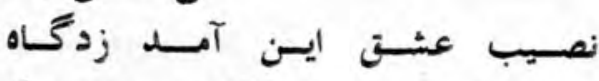

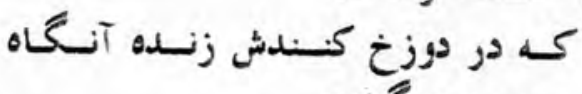

$$
\text { ميسن نسوز و آتسش جسون نسخـارد }
$$

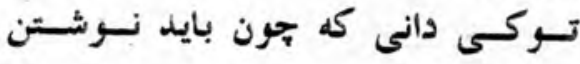

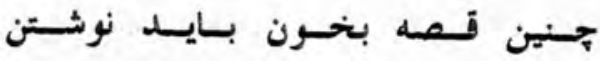

جـــ در دوزخ بعــــت روى دارم

بهـشت نسقـد از هـر ســوى دارم 
جسـ دوزخ آمسد از حسق حصه مسن

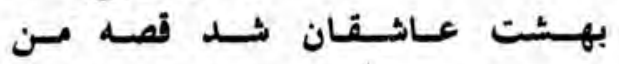

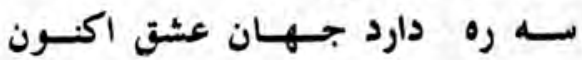

يكى آتش يكى اشك و يكى خهون

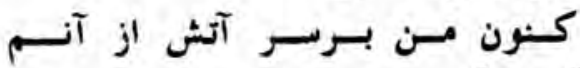

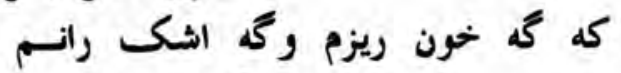

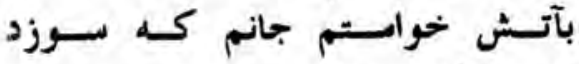

$$
\text { جـــ جساى تسـت نسترانـم كه سـرزد }
$$

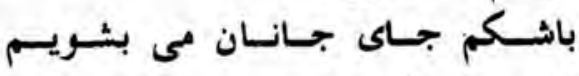

$$
\text { بخسونسم دست ازجسان مـى بشويسم }
$$

بــيسن آتش كه از جان ميسفــروزم

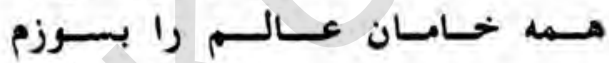

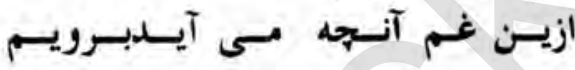

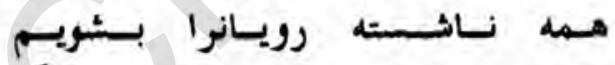

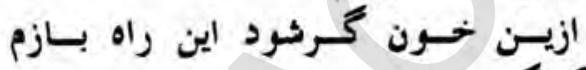

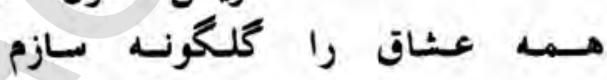

ازين آتش كه من دارم درين ســوز

نميايم هفت دوزخ را كه بين سوز آيث

ازين اشكم كه طوفانيست خــــــــــار

دهـم تعلـيم بازانرا كـــه جون بـار

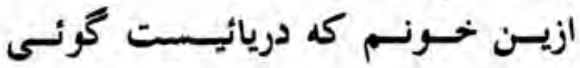

$$
\text { در آمسـوزم شفـق را سـرخ روائسى إنس }
$$

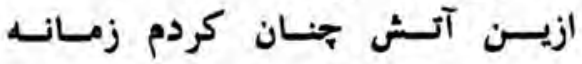

كه دوزخ نحواست ازمن صد زبانه

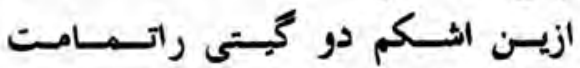

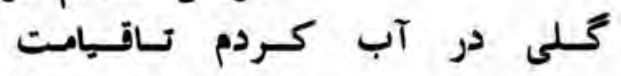

ازيسن خــون بـاز بسـتم راه خـردون 
كه تاگتبت آسياى جرخ برخون

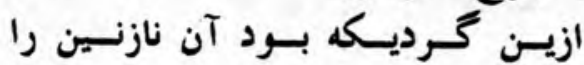

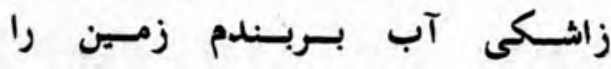

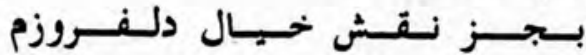

بـديسن آتش همى نقشى بسـوزم

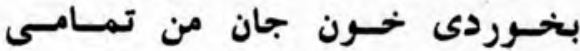

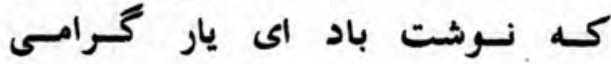

كنون در آتش و در الشكى ور درخون

بــرفتم زين جهان جيسفه بيـرون

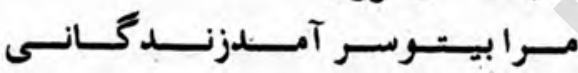

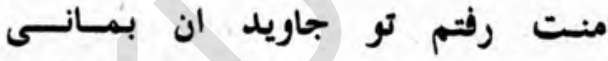

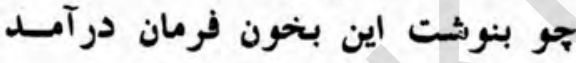

كه تازان بى سر وبن جان برآمد

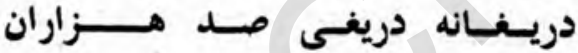

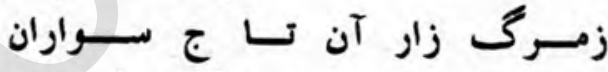

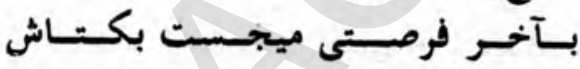

كـه بخت از زير جاه آورد بالاش فـ فرص

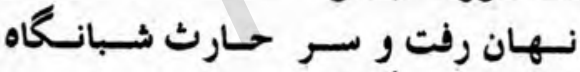

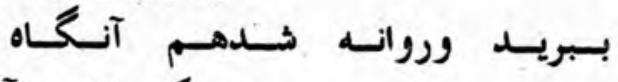

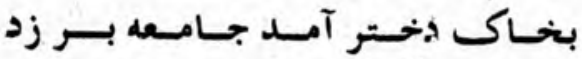

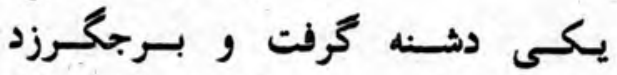

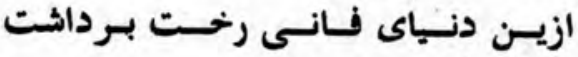

دل از زنــدان و بند سخت بــــاشـت

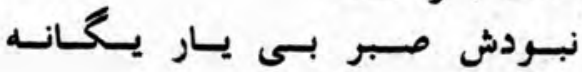

بــدوبـيوست و گـرنــهـ شـد فسانسه 


\section{در ير ده نشيان ستخنكوى نوشته شلده است :}

اوليز شاعره زيان فارسيكه در تذكره از او نام برده شده رابعه

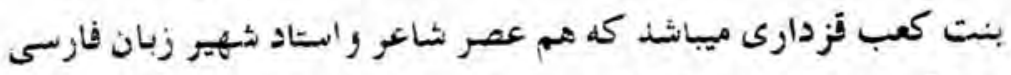

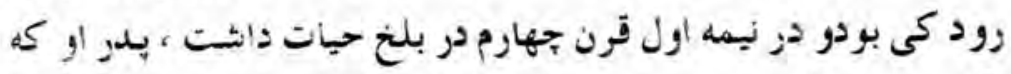

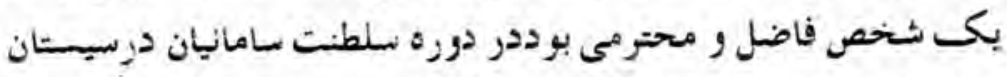

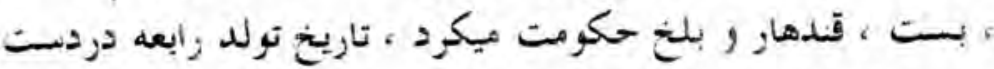

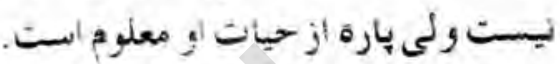

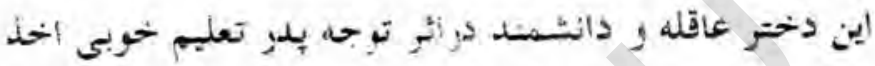

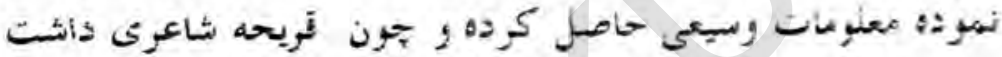

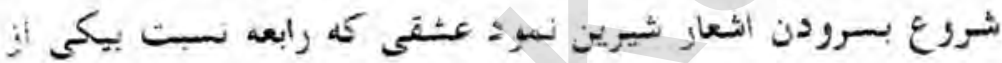

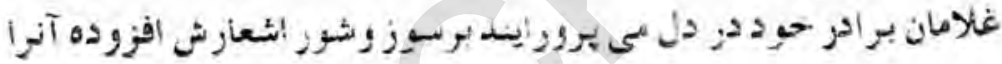

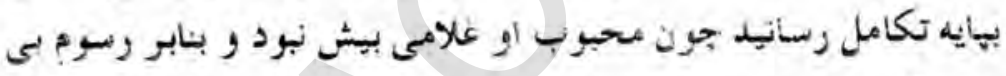

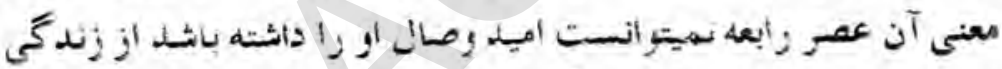

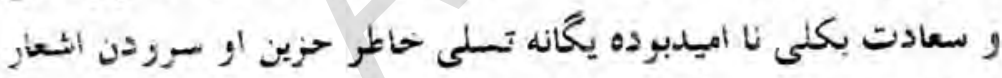
بودكه درآن احساسات سوزان و هيجان روحى خود رابيان مينسود ، كويندروزى . بودي

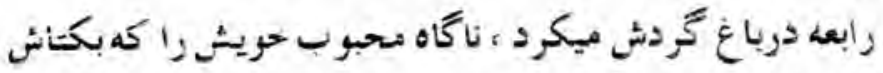

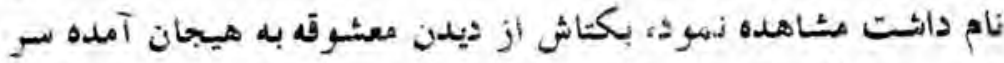

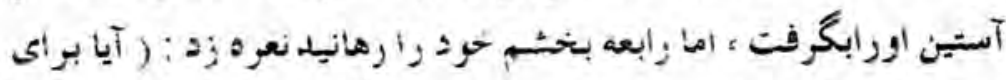

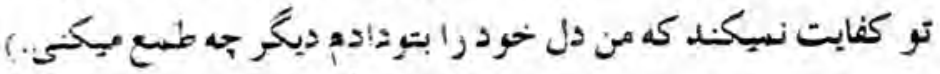

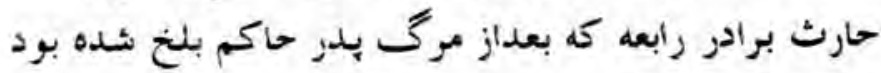

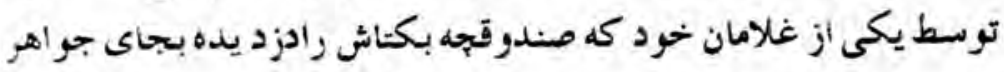


وطلا در آن اشعارمملوازعشق وسوز و گداز رابعه رايافته وآنرا بغرض

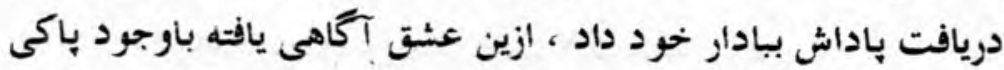

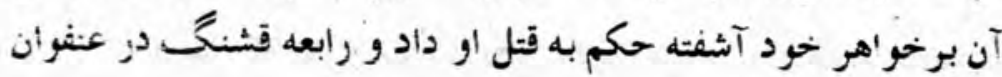

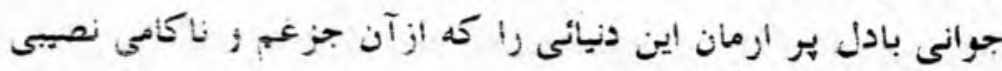

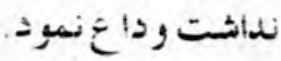
آخرجه تعداد بسيار محدود جيزى ازاشعار رابعه باقى نمانده

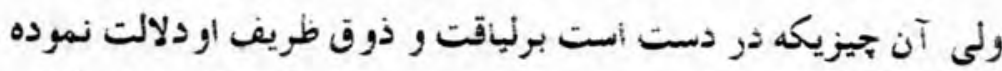

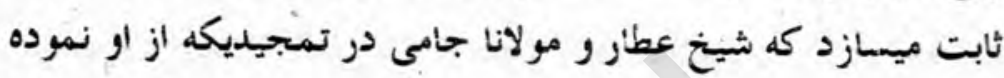
مبالغه نكرده اند ميسمازد

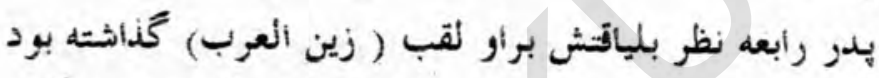

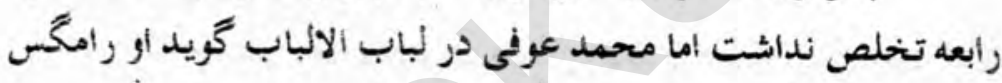

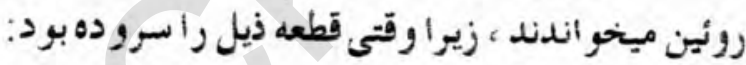

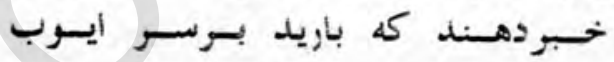

ز آسـمان ملخحان , ســرهنه زيس زيس

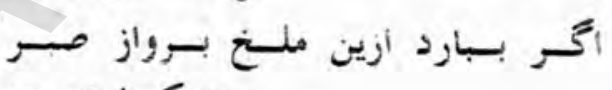

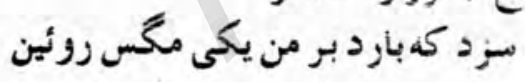

** * *

$$
\text { ووش بـرشاخكـ درخست يكى مرغ }
$$

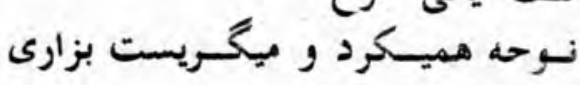

$$
\text { مسن جسدايسم زيسار خويسش نسـالم }
$$

تسوجسه نسالسى كه باسسعسادت بـأرى

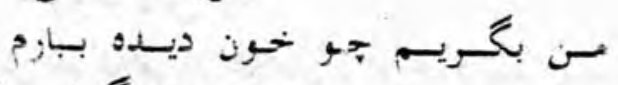

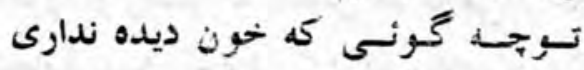
اين بود تحقيق دوشيزه ماگه رحمانى كه در برده نشينان 


\section{سخنگُى از آن ياد كرده است.}

\section{در نفحات الانس جامى جنين ذكر شـده است:}

دختر كعب رحمهالله تعالى' ،ثيخ ابوسعيد ابوالخير قدس الله

تعالى سره كفته است كه دختر كعب عاشق بود برغلامى اما بـران همه اتفاق كردند كه اين مخن كه او ميخويد نه آن سخن باشد كه بر مخلرت

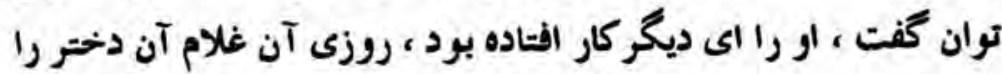

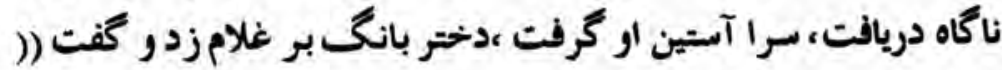

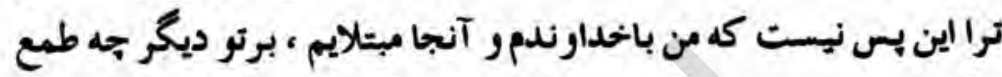
ميكنى ، شيخ ابوسعيد كفت ، سسخنى كه او كفته ابست نه جنان است كه

كسى رادر مخلوق القتاده باشد.

در مجمع الفصحاتحت عثوان رابعه قزدارى بلنى جين ذكر

كرويده امتث:

رابعه از نسوان وملك زادگان است ، بلدرش كعب نام در اصل از اعراب بوده ، در بلخ ، قزدار و بست در حوالى قندهارو بسيستان و حرالى بلخ كامرانيها نمرده ، كعب بسرى حارثنام داشته و دخترى رأبعه نامه او رازين العرب نيزمى كُفتبلد رابعه مذكرره در حسن و جمال وفضل و كمال ر مرفت و حال وحيده روزگًر و فريده دهروادوار بوده ، صاحب عشق حقيقى و مجازى وفارس ميدان فارسى و تازى بوده عاحوالث درخاتمه نفحات الانس مولينا جامى درضهن نسران عارفه مسطور الست و دريكى از مثريات ثيخ عطار مجملى ازحالاتش نظماً مذكور، او راميلى به بكتاش نام غلامى از غلامان بر ادرخود بهم ربيده

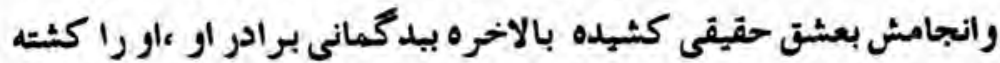
حكايت ار رافقير نظم كرده نام آن مثنويا گلسـان ارم نهاده ومعاحر برآل 
سامان ورودكى بوده واشعار نيكو ميفرموده.

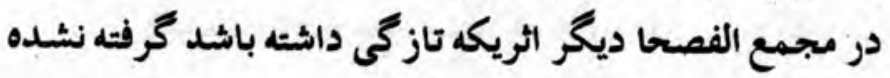
است واشعار محدود آنرا انتخاب نموده است. مولانا خسته عالم محق بلنحى در دبيرستان بلخ اثر دقيق

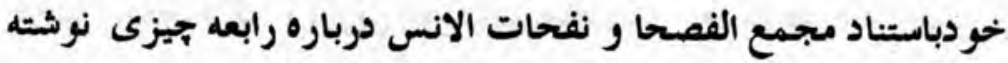

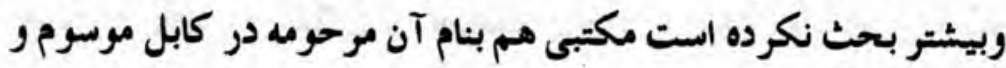

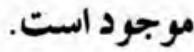

تاريخ ادبيات ايران ، جلداول صفحه (ror. ror

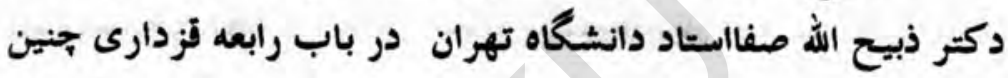
مينويسد:

رابعه بنت كعب قزدارى بلنحى ازشاعران مشهور قرن جهارم

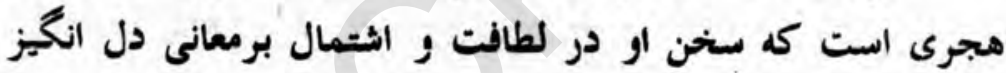

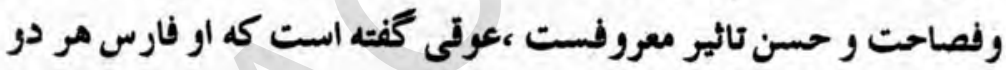

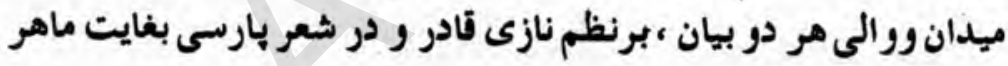

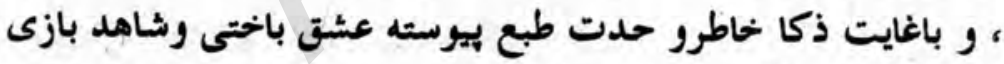

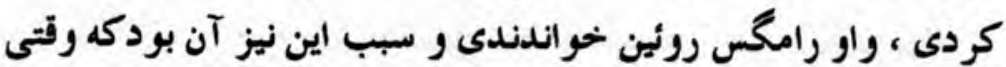

$$
\begin{aligned}
& \text { شعرى گفته بود : }
\end{aligned}
$$

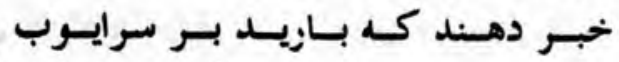

ز آسـمان ملـخان و سرمــمه زرين

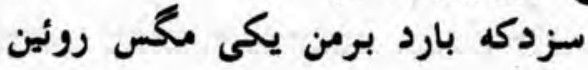

$$
\text { اگحربـبارد ازيسن ملـخ بــراواز حسبر }
$$

جامى (1) نام او را درشماره زنان زاهد و صوفى آورده و از بردي

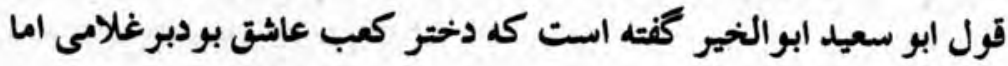


عشق اواز قَبيل عشقهاى مجازى نبود.

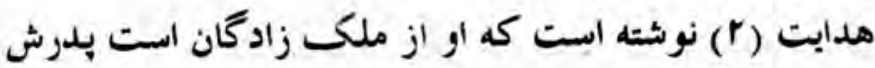

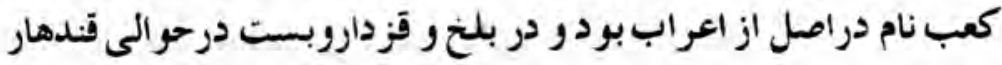

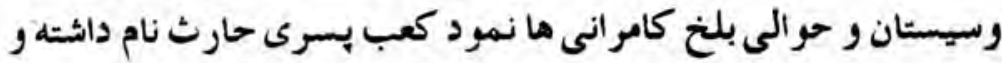

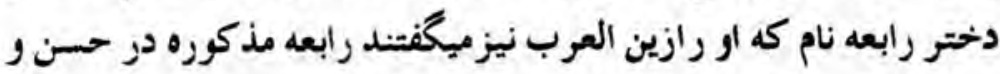

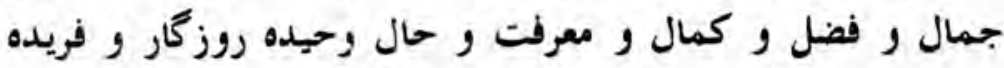

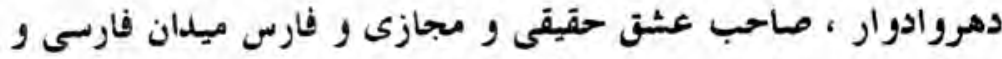

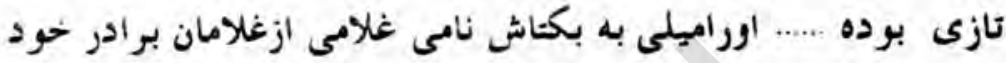

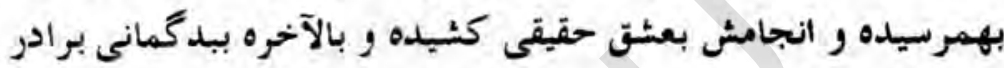

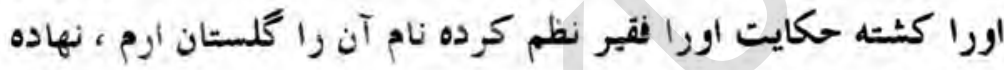

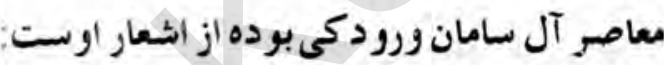

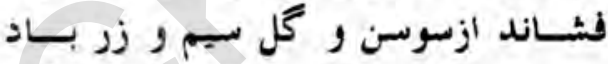

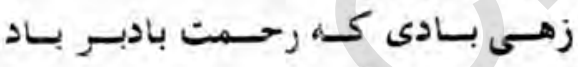

بــداد از نستــ آذرصد نشــان آب

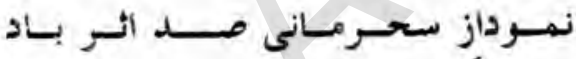

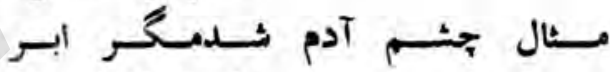

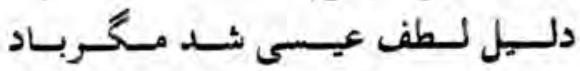

كــه دربساريسـد مهـردم در جسمن ابسر

كه جان افزود خوش خوش در شجر بـر باد

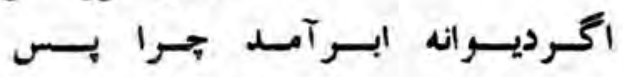

كــدعـرضه صسبوحسى جــام زربـاد

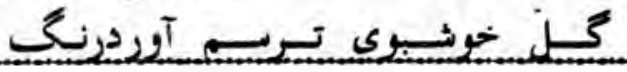

$$
\begin{aligned}
& \text { ryr (1) } \\
& \text { rrr مجمع الفصحاء ع (r) }
\end{aligned}
$$


ازيسن غمبـازصبـح بـرده دزبــار

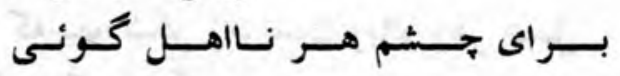

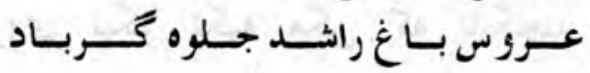

$$
\text { عجب جون صبح خوشتر ميبرد خواب }
$$

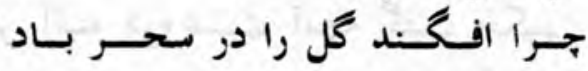

*** * *

$$
\text { عشـق اوبــاز انسـدر آوردم بــه بــند }
$$

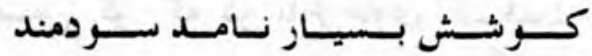

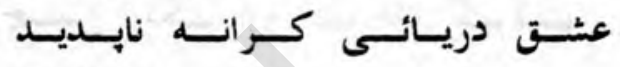

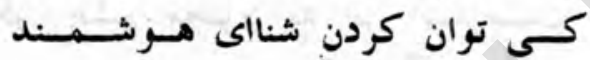

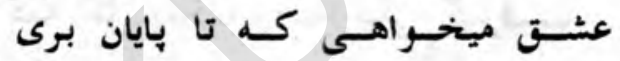

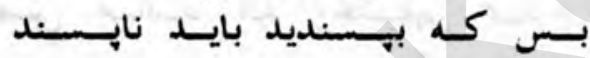

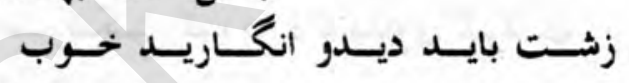

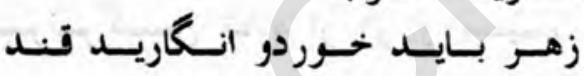

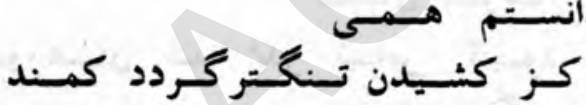

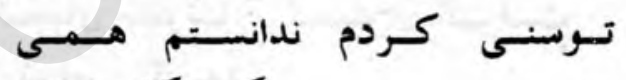

*** * *

دعوت من برتوآن شد كايزدت عاشق كناد

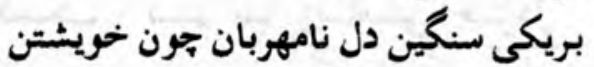

تابدانى درد عشق و داغ مهر و غم خورى نائي

تابه هجر اندربه بيجهى وبدانى قدرمن

* * * تابه

$$
\text { مـرابه عشق همى متهم كـنى به حسيل }
$$

جه حجت آورى بيش خيداى عزوجل

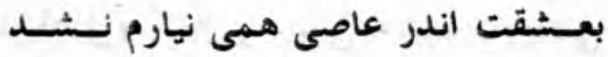

بدينم انسلدر طاغى همى شوم بمستل 
نعيم بيتر نخواهم جحسم باتو رواست

كه بيتو شكر زهر است وبتو رباتو زهر عسل

بروى نيكو تكيه مكن كه تايكهند

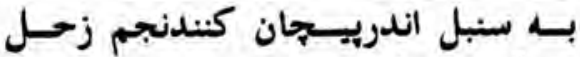

هر آئينه دروغست آنجه گفت حكيهم

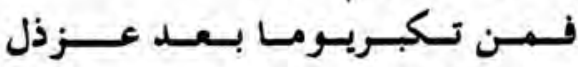

***

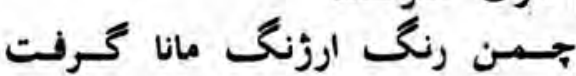

زبسـ گل كه در باغ مارى گـرفــت

مكر جشم مجنون به ابر انسلروستـ

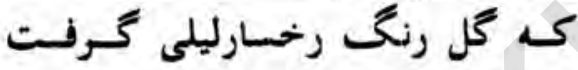

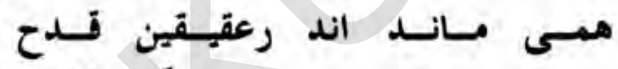

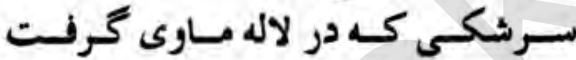

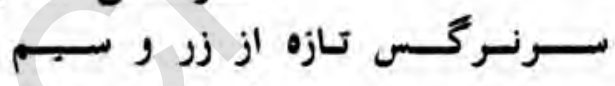

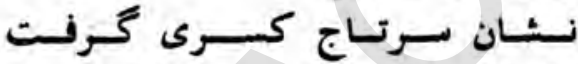

جسورهـبان شد اندر لبـاس كبــود

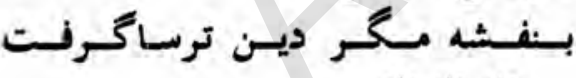

*** * *

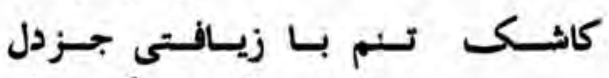

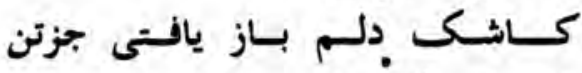

$$
\text { كاشكـ من از تو برستمى بسـلامست }
$$

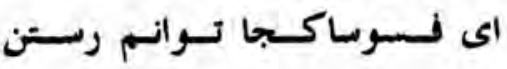

مولف كتاب رود كى ميگويد : اخرخطا نكنيم يخانه شاعره

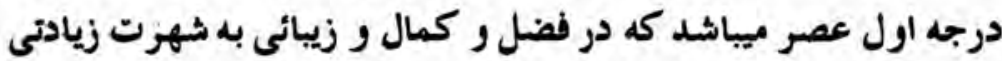

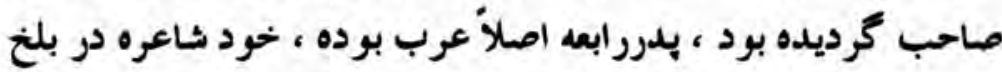


تولد شده و جندى درآنجا نشور نمايالته است اين رابعه غير ازرابعه عدويه ميباشدرابعه عدويه از صوفيان عصر بوددر خيلبى سر جشمهه هارابعه ديه

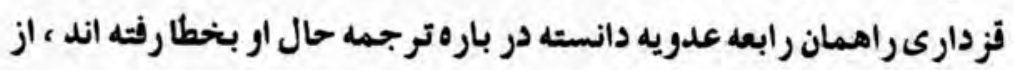
جمله درتذكره دولششاهى سمرقندى همين حالت ديده ميشودر متاسفانه

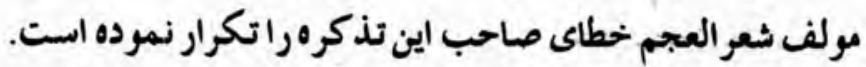

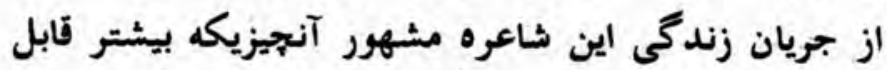

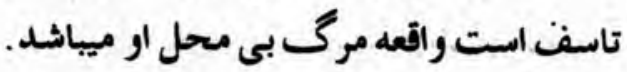

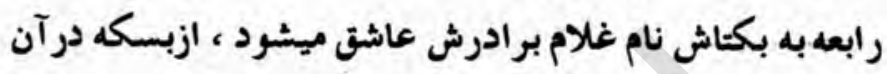

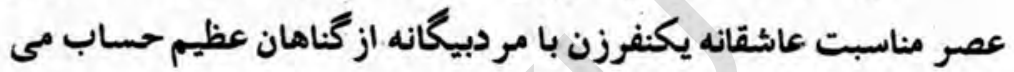
شداو رابنا برممين سبب درجوانى بقتل ميرساند.

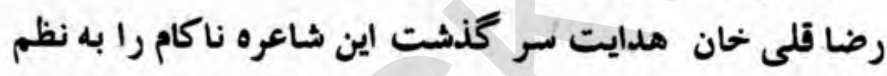

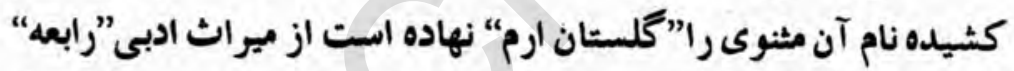

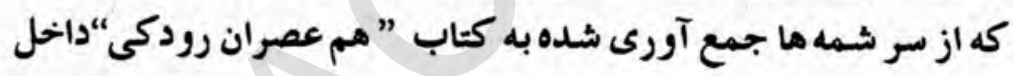

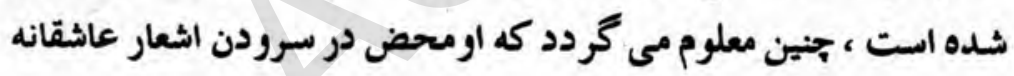

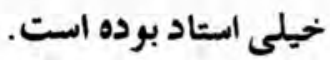
اين بود معلومات محترم وميرزا ترسون ر عبدالغنى ميرزابرف مرلف رو رودات مرتب كتاب رودكى درباب رابعه بلكى كه درينجا بنام يكى ماخذ معتبر نقل شد.

زين العابدين موتمن در رساله " شعر و ادب فارمى" تحت

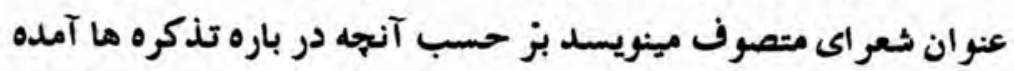

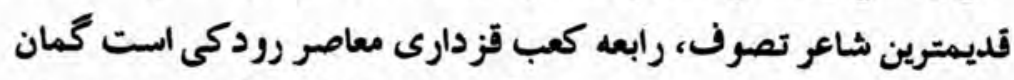

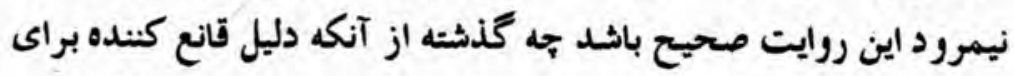

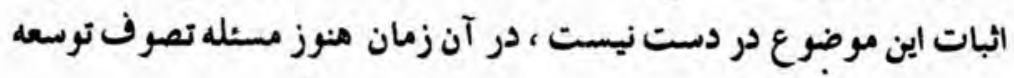


و عموميتى بيدا نكرده بودكه حتى زنى برده نشين در حلقه اهل تحقيق در

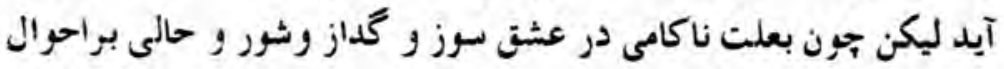

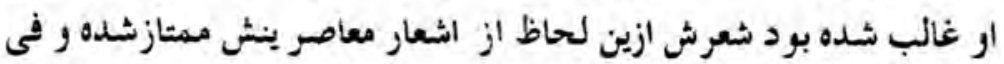

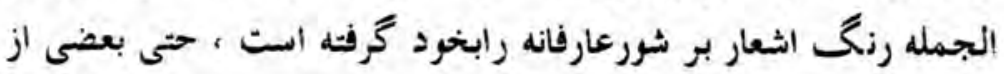

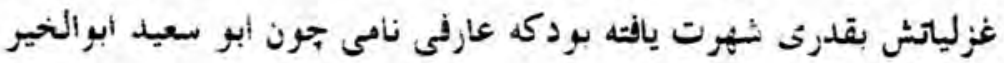

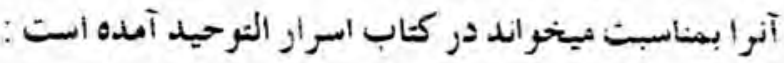

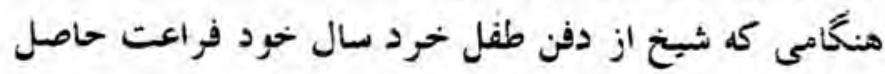

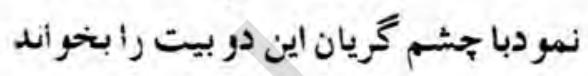

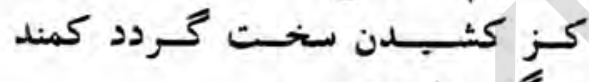

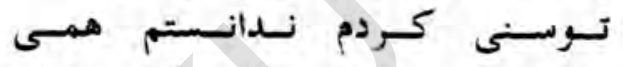

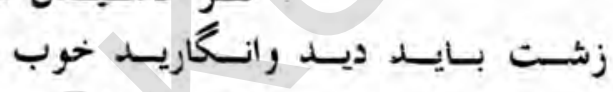

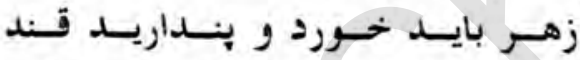

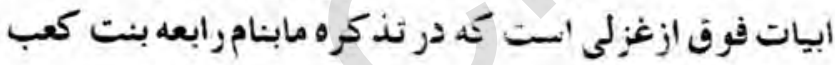

ثبت شده است.

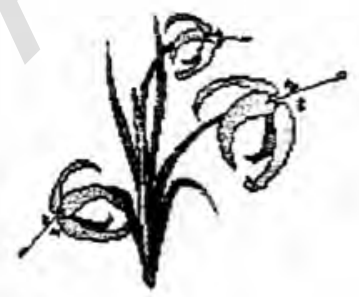




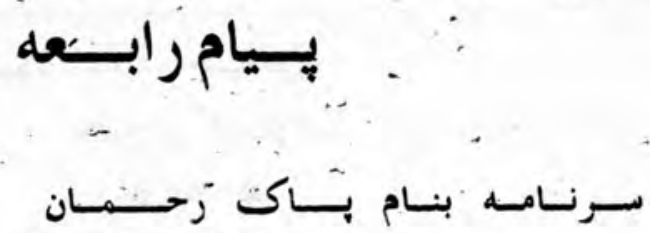

كه لطفش عام برانس است و هم جان

$$
\text { بــهله بعضــى ميــدهد جــاه و ززرو مــال }
$$

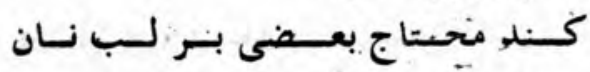

$\therefore$ * * * *

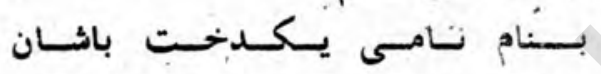

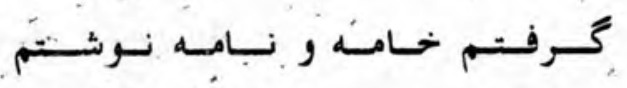

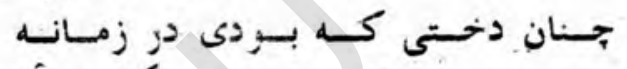

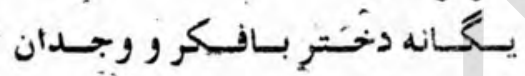

بـونو ايسن نساعه بـس بـرمايه و نـغسز

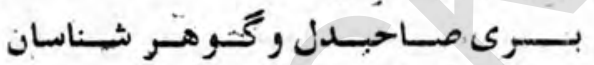

زروذ دز انجسمن غسرغا نمسايسد

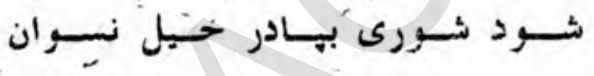

*** * *

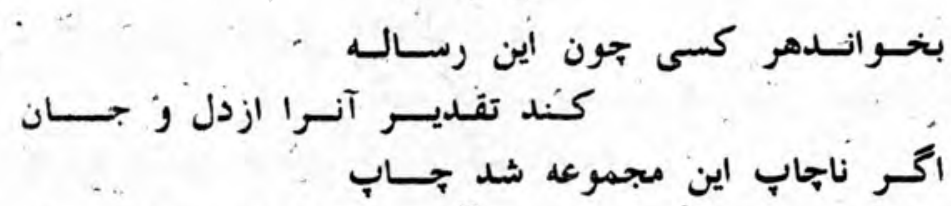

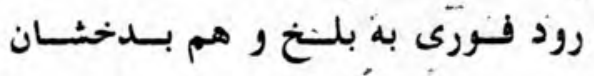

* * *

$$
\text { درايسن دفستر بــود افـنسأب عـشّت }
$$

زنسـد ايسن عشتق نسشتر درزق جان 
شهـيد عشـق خسـود مانند منسـور

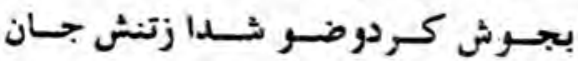

* * * *

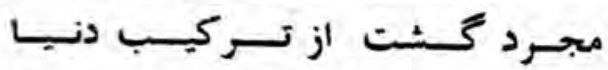

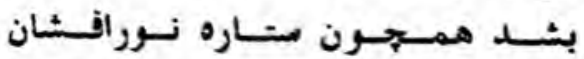

$$
\text { عنسان خـــود بـدت نسفيس كــى داد }
$$

بـــر انـــلـاز خود هوا و نفس و شيطان

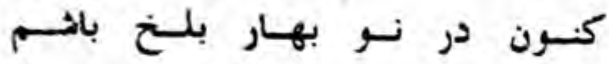

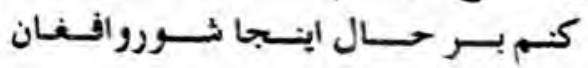

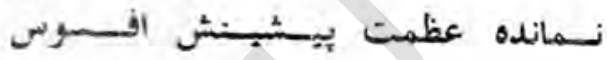

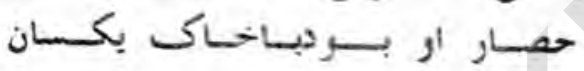

*** * *

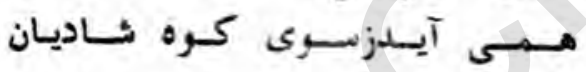

بخـوش مسن نسوا هـاى هـيسنى

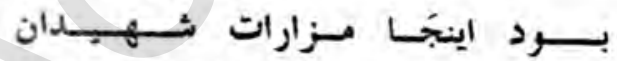

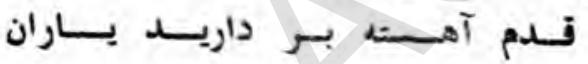

* * *

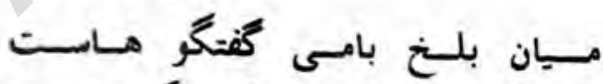

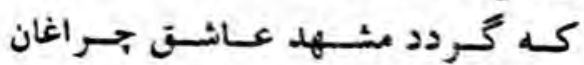

$$
\text { شـود ايسـن خـاك ثـورانگيز آبـاد }
$$

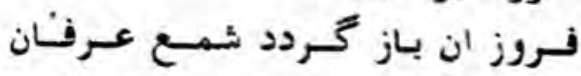

* * *

زخـاكى رابسعه خبـز مدائسى

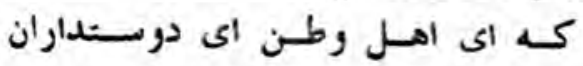

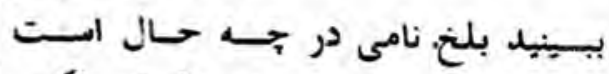

بحسالـش فكــياى جمسع عـزيزان 
بـائسيد انسجمن بـر بـا نمائسيد

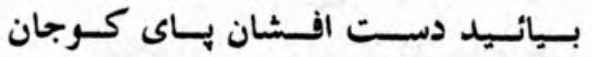

$$
\text { بيسائيسـد حسلقه حلقه دسـته دسـته }
$$

شـــود تــا روح مسن خنسـدان وشادان

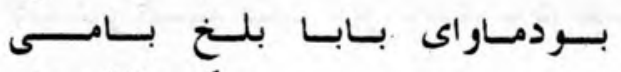

مـكن غفلت شودزين بيش ر بــــــان

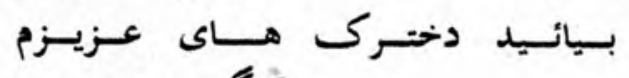

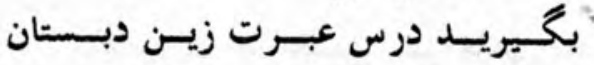

** * * *

$$
\text { شــدم از عشــق حسق افسانه جون من }
$$

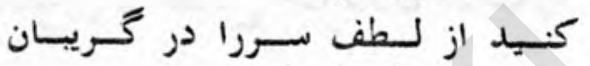

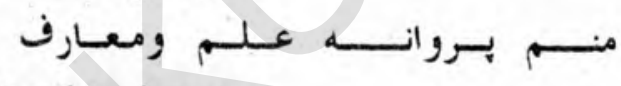

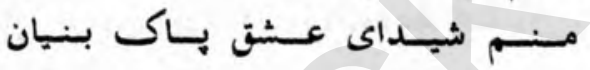

*** * *

$$
\text { جسومسن گــرديسد خود بابند ناموس }
$$

كـه باشــيد ، همجيـومن مشهور دوران

$$
\text { بـه عـفت بـوده عشق باكى ور زيسـد }
$$

زنسامحسرم بجيسـيد جيسن دامسـان

بلخ اعسا أنوابى

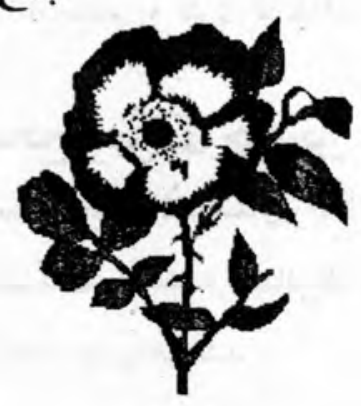




\section{سو انح مختصعر نزيسنله}

غلام حبيب نوابى و لد غلام حيدر تيمورى ساكن كوهدامن

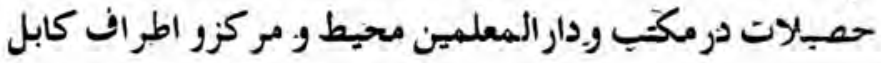
مطالعات عميق در تاريخ ادبيات و فلسفه حيات نوين تحقيقات درانفس وآفتاق تتبعات وتحقيقات در بيرامون احتياجات نسل نوو ايجابات عصر حاضر نموده ام.

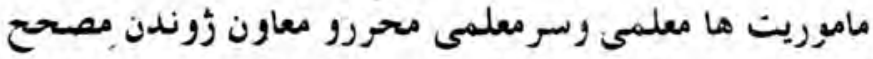

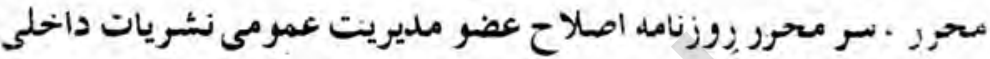
معاون و كفيل جريده اتحاد نضر انجمن ثنازيخ معارن و مدير جريده وروزنامه بلدحشيان

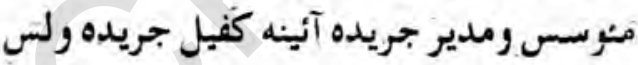
رنيس افتخارى سره مياتست ولايت جوزجان

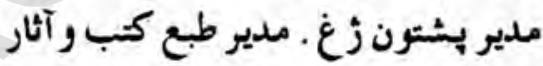

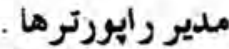

مؤسس و مدير جريده ديوه بالاخره مدير جريده كلى

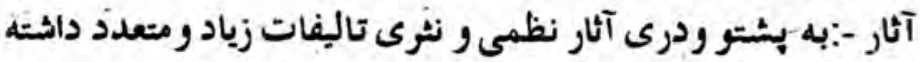

مؤلف مدون ، مصجِح و مرتب جتندين آثارمطبوعم

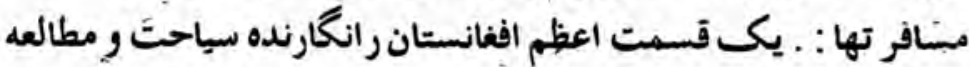

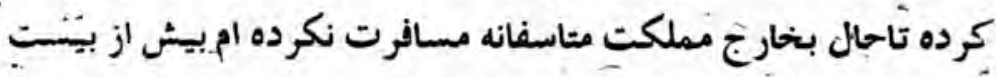

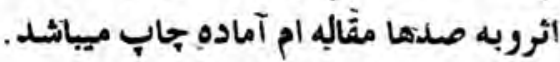


مآخذيكه درين كتاب مورد استفاده واقتباس قرار گرفته است :

$$
\begin{aligned}
& \text { 1- نفات الانس } \\
& \text { r r مجمع الفصحاء } \\
& \text { r. كلهاى خود رو } \\
& \text { r. برده نشينان سخنكوى كله } \\
& \text { هـ كنج سخن } \\
& 4 \text { ب بشتنى ميرمنى } \\
& \text { ـ. كتاب رودكى لئى }
\end{aligned}
$$

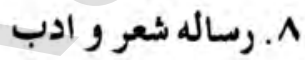

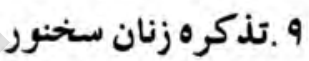

$$
\begin{aligned}
& \text { • | ا- تاريخ ادبيات ايران } \\
& \text { | } 1 \text { - دبيرستان بلخ } \\
& \text { r ا I ا-لهىنامه } \\
& \text { ما | اسرارالتوحيد }
\end{aligned}
$$

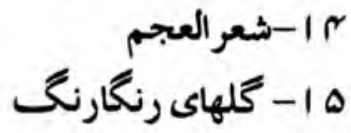

$$
\begin{aligned}
& \text { 4 ا - كلستان ارم وغيره }
\end{aligned}
$$




\section{رحمت باد برباد}

فشاند از سوسن و گل سيم و زر بـاد زهـى باديـكه رحسمت بـاد بربـاد

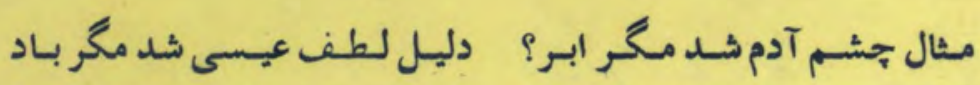
كـه در باريد هر دم در جمن ابسر كه جان افزود خوش خوش در شجر باد كل خوشبوى ترسم آورد رنخـ ازيسن غـماز صبـح يـرده در بـاد

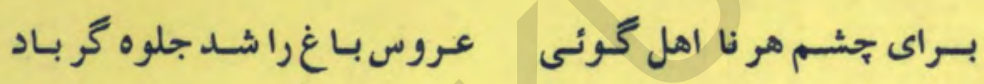

\section{عجب جون جسم خوشتر ميرودخواب

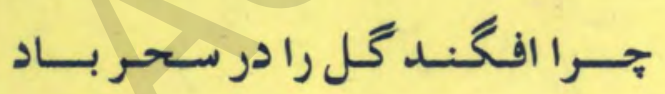

(رابعه بلنخى)

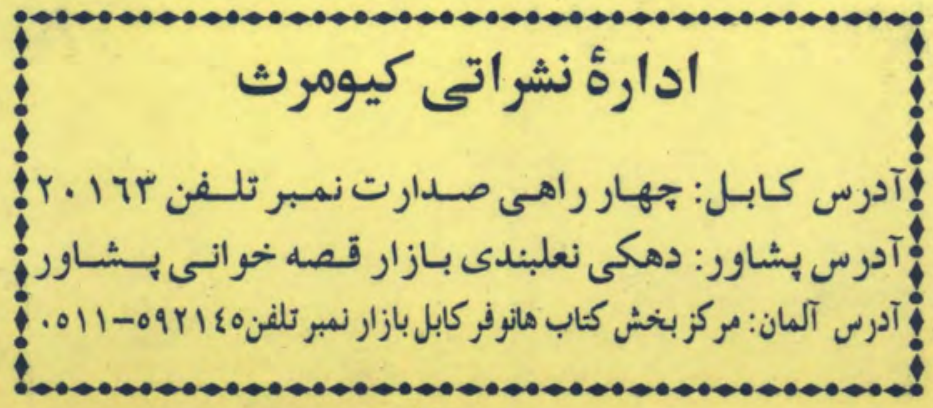

